\title{
Archaeological Services Associated with Improvements to Miraflores at Brackenridge Park,San Antonio, Bexar County, Texas
}

Kristi M. Ulrich

Follow this and additional works at: https://scholarworks.sfasu.edu/ita

Part of the American Material Culture Commons, Archaeological Anthropology Commons, Environmental Studies Commons, Other American Studies Commons, Other Arts and Humanities Commons, Other History of Art, Architecture, and Archaeology Commons, and the United States History Commons

Tell us how this article helped you.

This Article is brought to you for free and open access by the Center for Regional Heritage Research at SFA ScholarWorks. It has been accepted for inclusion in Index of Texas Archaeology: Open Access Gray Literature from the Lone Star State by an authorized editor of SFA ScholarWorks. For more information, please contact cdsscholarworks@sfasu.edu. 


\section{Archaeological Services Associated with Improvements to Miraflores at Brackenridge Park,San Antonio, Bexar County, Texas}

\section{Creative Commons License}

\section{(c) (1) (8)}

This work is licensed under a Creative Commons Attribution-NonCommercial 4.0 International License 


\title{
Archaeological Services Associated with Improvements to Miraflores at Brackenridge Park, San Antonio, Bexar County, Texas
}

\author{
by
}

Kristi M. Ulrich

with contributions by

Antonia L. Figueroa

Texas Antiquities Committee Permit No. 4653

\section{Principal Investigator \\ Marybeth Tomka}

Prepared for:

Rehler Vaughn \& Koone, Inc.

745 E. Mulberry Ave. Suite 601

San Antonio, Texas 78212-3186

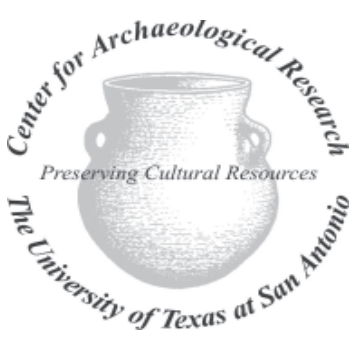

(C) 2008
Prepared by:

Center for Archaeological Research The University of Texas at San Antonio Archaeological Report No. 387 



\begin{abstract}
:
In September and October of 2008, the Center for Archaeological Research carried out archaeological testing of Miraflores Park located on Hildebrand Ave between the San Antonio River and the AT\&T parking lot. A total of 122 shovel tests were excavated within the project area on a modified $10 \times 10 \mathrm{~m}$ grid. In addition to the shovel tests, four $50 \times 50 \mathrm{~cm}$ units and one 50 $\mathrm{x} 100 \mathrm{~cm}$ test unit were excavated to gain more information of certain areas. Four hand-excavated trenches were dug within the project area in order to uncover encountered features. Testing revealed a prehistoric component in the northeast portion of the property. Also, it appears that large portions of the park were filled in after it was sold to USAA. When construction commences on the park, CAR recommends that archaeological monitoring occur during construction/rehabilitation of the park in areas that archaeological investigations and archival research indicated that buried features may be found.
\end{abstract}

The archaeological investigation was conducted under Texas Antiquities Permit No. 4653, with Marybeth Tomka serving as Principal Investigator. All artifacts collected were processed in the Center for Archaeological Research laboratory, where they remain for permanent curation. 


\section{Table of Contents:}

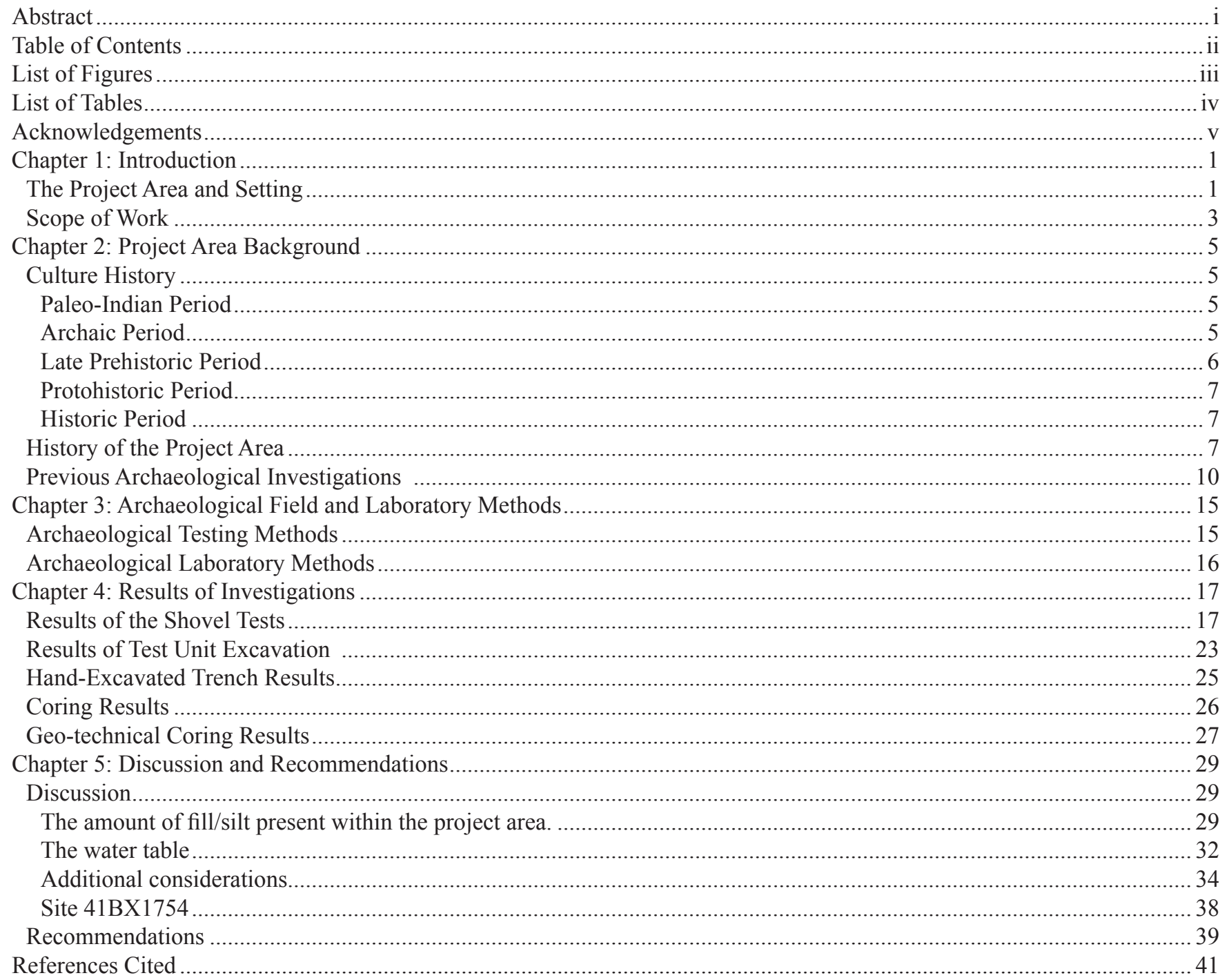




\section{List of Figures:}

Figure 1-1. The location of the Miraflores (41BX1754) project area on the San Antonio East USGS quadrangle map 1

Figure 1-2. The Miraflores Project area.

Figure 2-1. Map of the portions of land delineated by Don Juan Antonio Perez de Almazan, Alcade Mayor, in 1731

Figure 2-2. Photograph of the library tower ca. 1930

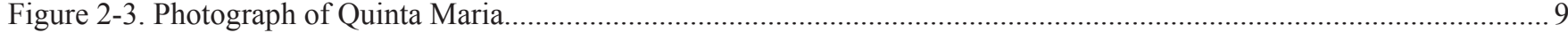

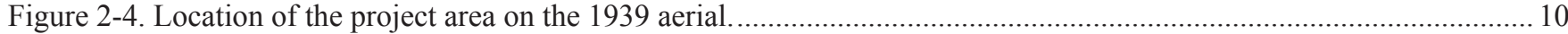

Figure 2-5. Photograph of bench created by Dionicio Rodriguez. ................................................................................... 11

Figure 2-6. Photograph of the gate that was located on Broadway before being relocated to the San

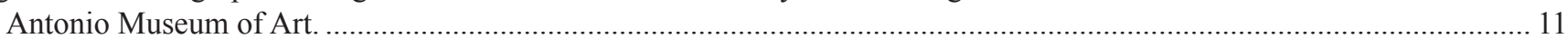

Figure 3-1. Map of the project area showing the location of the proposed shovel tests.......................................................... 15

Figure 4-1. Map of the location of the shovel tests, units and trenches excavated within the project area.

Figure 4-2. Photograph of Test Unit 2, located within the reflecting pool. ............................................................................2. 23

Figure 4-3. Photograph of the cement feature uncovered in ST 33 and Trench 3 …......................................................26

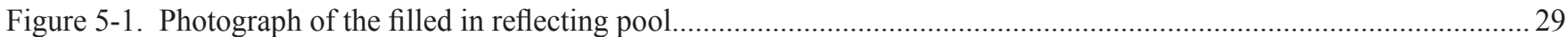

Figure 5-2. Photograph of Shovel Test 99 revealing portion of brick pathway below surface. .............................................30

Figure 5-3. Recent photograph of the Banco del Amor. Fill completely covers the bench seat...........................................30

Figure 5-4. Historic and recent photograph of the stage indicating the amount of fill present today.....................................3 31

Figure 5-5. Historic and recent photograph of the lower and upper pool........................................................................... 32

Figure 5-6. Comparison of historic and recent photographs of the path leading alongside the upper pool.

Figure 5-7. Photograph taken by family members in 1995 showing the gravel path and reflecting pool in background.

Figure 5-8. Comparison of historic and recent photographs of the artesian well fountain....................................................... 35

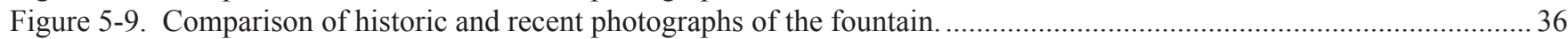

Figure 5-10. Photograph of standing water found in the northwest portion of the project area prior to the testing. .37

Figure 5-11. Photograph of water seeping into Unit 1 located along the reflecting pool path. ...........................................37

Figure 5-12. Photograph of the unknown feature uncovered in Shovel Test 109..............................................................38

Figure 5-13. Photograph of the brick paved path outside of the library footprint. ..............................................................39

Figure 5-14. Photograph of Shovel Test 117 revealing the edge of the swimming pool........................................................39 


\section{List of Tables:}

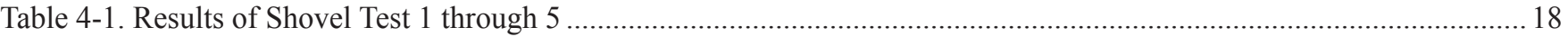

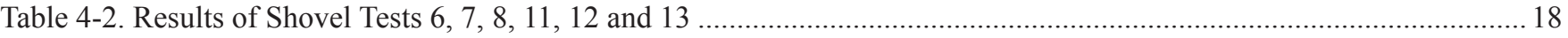

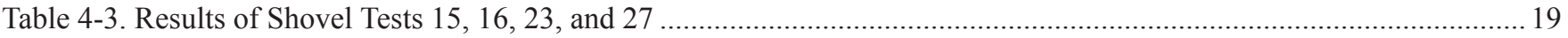

Table 4-4. Artifacts Recovered from Shovel Tests 96, 97, 104, and 106........................................................................20

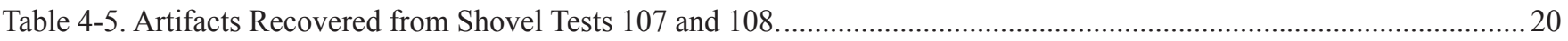

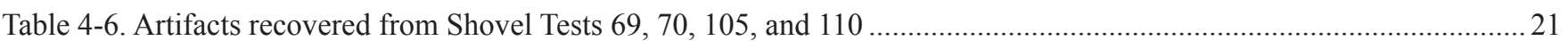

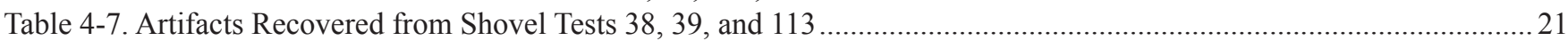

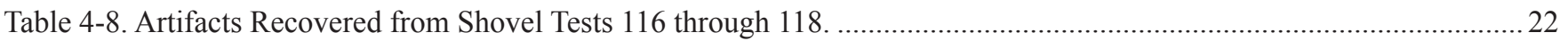

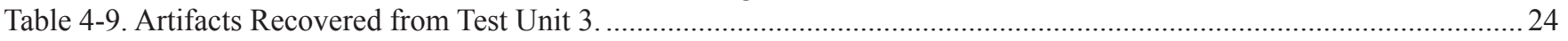

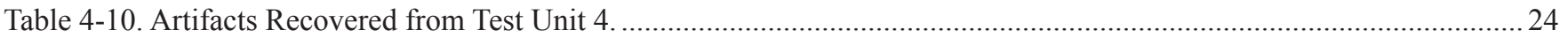

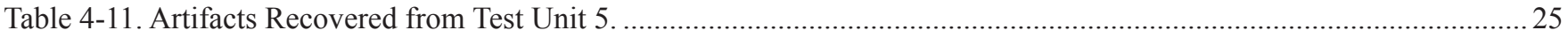

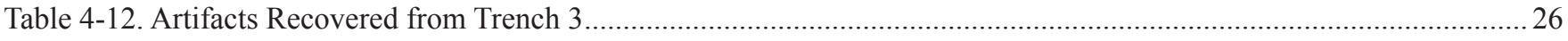

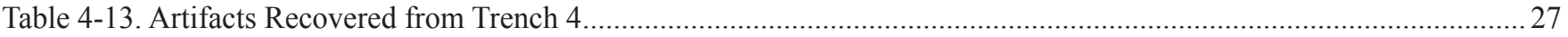




\section{Acknowledgements:}

The author would like to extend thanks to the individuals that aided in the successful completion of the project. Special thanks go to the Miraflores Project Team including Kimberly Wolf, Cheryl Hicks, and Desiree Salmon from Rehler Vaughn \& Koone, Inc., Sarah Lake of Sarah Lake Landscape, and Maria Pfeiffer.

The field crew consisted of Lindy Martinez, Jason Perez, Cathy Stacy, Jon Dowling, Nate DiVito, and Cyndi Dickey. Marybeth Tomka served as Principal Investigator and oversaw all lab processing and curation. Thanks go to Bruce Moses for the TDS mapping and production of the figures in the report. Bruce also served as Technical Editor for this report. Also, thanks to Dr. Steve Tomka, CAR Director, for his oversight and guidance during the course of the project. 



\section{Chapter 1: Introduction}

The Parks and Recreation Department of the City of San Antonio has contracted with Rehler Vaughn \& Koone, Inc. to develop a master plan and design and construction documents for the Miraflores project at Brackenridge Park, in San Antonio (Figure 1-1). The 4.5 acre Miraflores Park is the only extant portion of a private park built in the 1920s for Dr. Aureliano Urrutia. The park contains a collection of approximately 30 sculptures, including several by noted sculptor Dionicio Rodriguez, and garden features set near the headwaters of the San Antonio River in north-central San Antonio. Miraflores Park is listed on the National Register of Historic Places and has prehistoric archaeological deposits buried below the surface above the 100 Year floodplain.
Escarpment of the Edwards Plateau. Major drainages near the project area include the San Antonio River, and Olmos Creek, which is located north of the project area. The headwaters of the San Antonio River are located just to the north of the project area, on the grounds of the University of the Incarnate Word. Within the project area, several small springs can be found bubbling when the water table is sufficiently high. The majority of the site is within the 100 year flood plain of the San Antonio River (FEMA 2007).

The soils of the project area are listed as Frio and Trinity soils of the Austin-Tarrant Association. These soils tend to be moderately deep to very shallow silty clay soils over chalk and marl (Taylor et al. 1991).

\section{The Project Area and Setting}

The project area is located in San Antonio, Bexar County, Texas, near the 800 block of East Hildebrand Avenue, across from The University of the Incarnate Word. The project area, located on the San Antonio East quadrangle map, is trapezoidal in shape (Figure 1-2), and is surrounded by a chain link fence on all four sides. A wrought iron gate is present on the north side flanked by two decorative fountain pieces. The San Antonio River bounds the west and southwest portions of the property.

The project area is situated in the geographic region referred to as South Texas. The region is bordered by the Edwards Plateau to the north, the Rio Grande River to the south, the Gulf of Mexico coastline to the east, and the Lower Pecos region to the west (Norwine 1995:138). The general topography of the project area is characterized by a gently rolling landscape cross-cut by seasonal drainages.

Bexar County is located in the transitional zone between the southern limits of the Edwards Plateau Escarpment and the lower Gulf Coastal Plain. San Antonio is located at the base of the Balcones

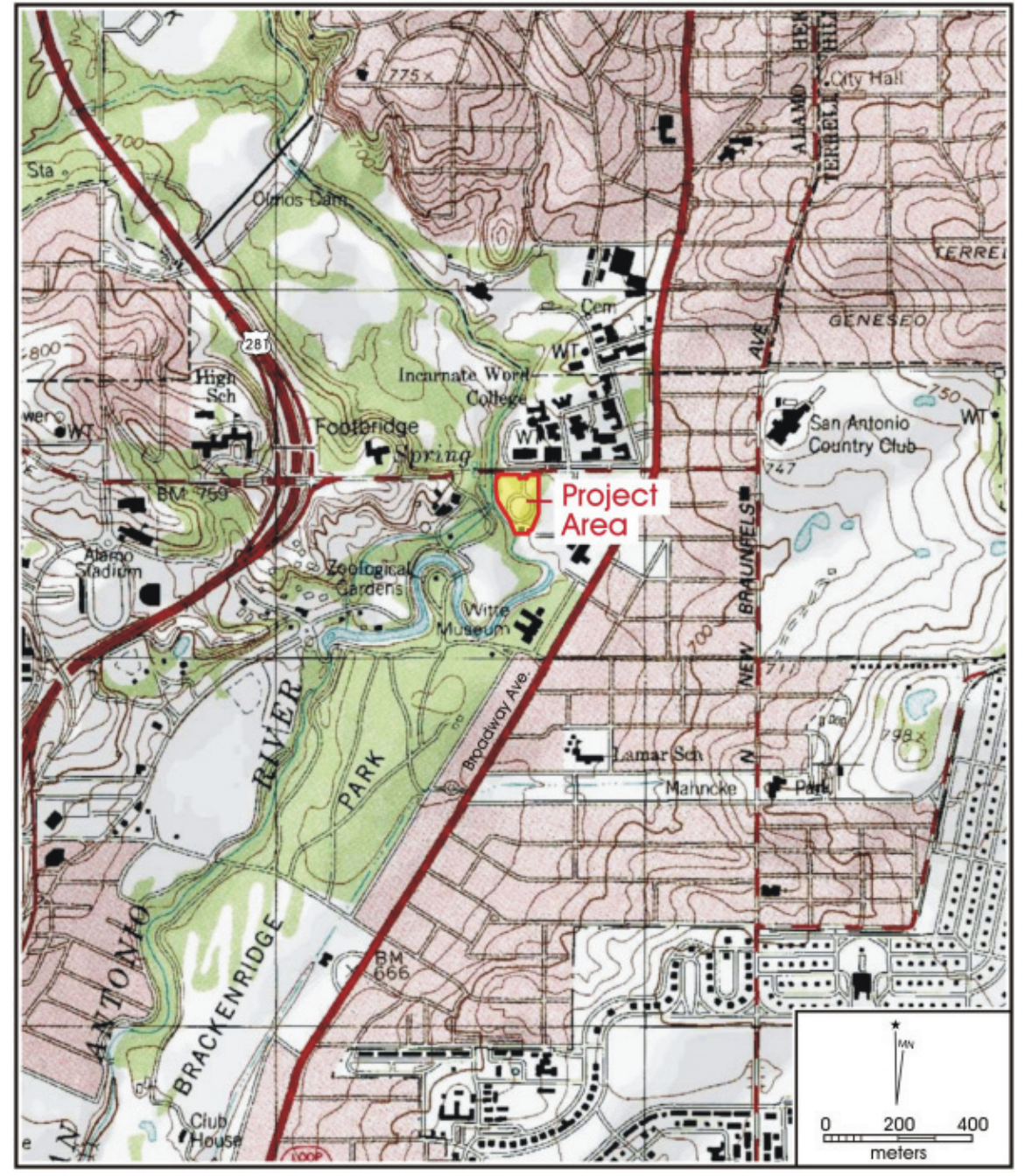

Figure 1-1. The location of the Miraflores (41BX1754) project area on the San Antonio East USGS quadrangle map. 


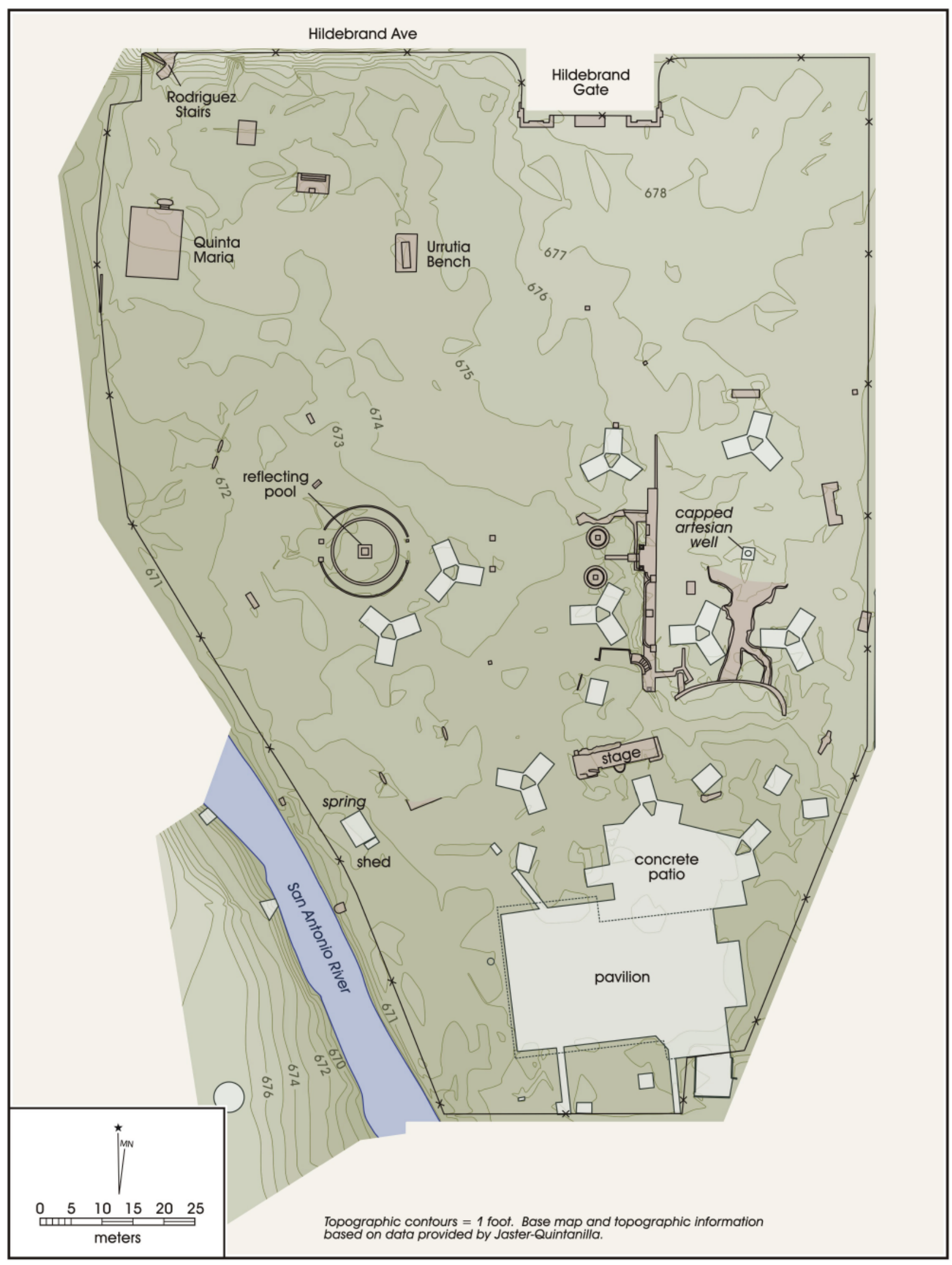

Figure 1-2. The Miraflores Project area. 
Three major geographic regions meet in Bexar County: the Edwards Plateau, the Blackland Prairie, and the South Texas Plains (SCTRWPG 2007). The Edwards Plateau gradually slopes to the southeast and ends in the Balcones Escarpment (Taylor et al. 1991). The limestone based Edward's Plateau is characterized by spring-fed, perennial streams that flow across the Balcones Escarpment (SCTRWPG 2007). Vegetation in the Edwards Plateau consists largely of Bald cypress (Taxodium distichum), live oak (Quercus virginiana), cedar elm (Ulmus crassifolia) and several species of grasses that include bluestem (Schizachyrium and Andropogon spp.), gramas (Boutelous spp.), Indiangrass (Sorghastrum nutans), common curly mesquite (Hiaria belangeri), buffalo grass (Buchloe dactyloides) and Canadian wild rye (Elymus Canadensis) (Fentress 1986).

The Blackland Prairies vegetation regime includes a variety of oaks, pecan (Cara illinoiensis), cedar elm (Ulmus crassifolia) and mesquite (Prosopis sp.). Grasses in this region include big bluestem (Andropogon gerardi), little bluestem (Schizachyrium scoparium), Indiangrass (Sorghastrum nutans), switchgrass (Panicum virgatum), sideoats grama (Bouteloua crutipendula), hairy gama (Bouteloua hirsuta), and a variety of others (Fentress 1986).

The South Texas Plains vegetation area supports subtropical dryland vegetation including honey mesquite (Prosopis glandulosa), live oak (Quercus virginiana), blackbrush acacia (Acacia rigidula), huisache (Acacia smallii) and Mexican Paloverde (Parkinsonia aculeate) (Fentress 1986).

Bexar County also falls within two of the six biotic provinces described by Blaire (1950) as the Tamaulipan and the Balcones. The Tamaulipan province spans from the Balcones Escarpment south into northeastern Mexico east of the Sierra Madre. It is generally covered with thorny brush species like acacias and mesquite but likely supported more grasses prior to historic modifications to the land (Black 1989).
The flora within the project area has been altered from its natural state during its use as Miraflores Park. Several species of trees and plants were introduced, while others were removed. Currently within the project area, the flora consists of St. Augustine grasses, magnolia, cypress, oak, juniper, palmetto, creeping vines, and wild mint.

Climate in South Central Texas is humid subtropical with hot and humid summers (SCTRWPG 2007). The hot weather is persistent from late May through September. The cool season begins about the first of November and extends through March. Winters are typically short and mild with light precipitation. Rainfall in the San Antonio area averages about 32.92 inches a year (SRCC 2007; based on monthly averages from 1971 to 2000). Temperatures range from an average high of $111^{\circ} \mathrm{F}$ to an average low of $0^{\circ} \mathrm{F}$. Monthly temperature averages range from $50^{\circ} \mathrm{F}$ in January to $84^{\circ} \mathrm{F}$ in August.

\section{Scope of Work}

The archaeological services provided by the CAR associated with the development of the master plan and design include the following: (1) conduct archaeological testing on the property to determine the location of extant but now buried architectural elements within the park; (2) where the nature and depth of impacts require, conduct archaeological testing to the depth of the projected impacts to determine whether the impacts will disturb significant architectural features or elements of the NRHP site and/or hitherto undocumented prehistoric deposits (i.e. new pedestrian bridge footings); (3) produce a technical report summarizing the results of the testing and provide recommendations for the master plan and design; (4) submit the draft report to Sponsor, the San Antonio Historic Preservation Office (SAHPO) and the Texas Historical Commission (THC) for review; and (5) revise the draft report according to reviewer comments and produce a final report satisfying permit requirements. CAR was to also prepare all artifacts recovered from the investigations and all project related documents for curation at the Center's curation facility. 



\section{Chapter 2: Project Area Background}

\section{Culture History}

The culture history of the region, in particular Bexar County, spans nearly 11,500 years. There are four periods discernible by changes in hunting and gathering technologies, material culture and the arrival of non-indigenous populations. These are Paleo-Indian, Archaic, Late Prehistoric and Historic. Coherent culture chronologies of Central Texas by Collins (1995) and Prewitt (1981) are the standard summaries adhered to by many researchers. Collins' culture chronology for Central Texas (1995 and 2004) is used as a basis in this section supplemented by resulted of recent research.

\section{Paleo-Indian Period}

The earliest culture period recorded is the Paleo-Indian period, which marks the first signs of human populations in the New World. It coincides with the end of the Pleistocene and spans roughly from $11500-8800$ B.P. (Collins 1995 and 2004). Current research has confirmed absolute dates at three sites in Texas, the earliest is from the Aubrey site in Denton County, with radiocarbon assays of $11,542 \pm 111 \mathrm{~B}$. P. and 11, $590 \pm 93$ B. P (Bousman et al. 2004: 48). Environmental data suggest that climate during the Late Pleistocene was wetter and cooler than it is today (Mauldin and Nickels 2001; Toomey et al. 1993), shifting to gradually drier and warmer conditions during the Early Holocene (Bousman 1998).

Early perceptions of Paleo-Indian populations viewed these hunter-gatherers as ranging over wide areas in pursuit of now extinct megafauna. This view of Paleo-Indian peoples, much like the dating of this period, is now being reassessed. While certainly exploiting Late Pleistocene megafauna, these peoples are perhaps better characterized as generalized hunter-gatherers with considerable reliance on small game and plants. The Lewisville site (Winkler 1982) and the Aubrey site (Ferring 2001) possess faunal assemblages with a wide range of taxa that not only include large mammals but small to medium ones as well. Little information seems to be available on the consumption of plant resources during this cultural period, though according to Bousman et al. (2004) the Late Paleo-Indian component at the Wilson-Leonard site reflects diverse exploitation of riparian, forest and grassland species. Analysis of skeletal remains indicates that the diets of the Paleo-Indian and later Archaic hunter-gatherers may not have differed so greatly (Bousman et al. 2004 after Powell and Steele 1994).
Clovis and Folsom fluted projectile points used for hunting megafauna characterize material culture from early PaleoIndian sub-period. Projectile points, such as Plainview, Dalton, Angostura, Golondrina, Meserve, and Scottsbluff, are diagnostic of the late Paleo-Indian sub-period. Typical site types associated with the Clovis sub-period are camp, lithic procurement, kill, cache, ritual and burial sites (Collins 1995). Meltzer and Bever (1995) have documented 406 Clovis sites in Texas. One of the earliest documented PaleoIndian sites, 41RB1, was a small playa site near Miami in Roberts County, Texas (Bousman et al. 2004:15). According to radiocarbon assays the maximum age for the Miami site is $11,415 \pm 125$ B. P. (Bousman et al. 2004: 47).

The most notable sites in Bexar County that contain PaleoIndian components include St. Mary's Hall (Hester 1978 and 1990), and Pavo Real (Collins et al. 2003). St. Mary's Hall, 41BX229, is located in northern San Antonio, Bexar County. The site was first encountered in 1972 during the construction of a house just outside the property of the St. Mary's Hall institution (Texas Handbook Online 2006). The Pavo Real Site, 41BX52, is located along Leon Creek in northwest Bexar County. The site was first encountered in 1970 and has been subsequently excavated (Collins et al. 2003).

\section{Archaic Period}

The Archaic period spans from ca. 8800 B.P. to 6000 B.P. Early Archaic, Middle Archaic and Late Archaic sub-periods, divide this period. In addition, Johnson and Goode (1994) divide the Late Archaic sub-period into Late Archaic I and Late Archaic II. During the Archaic, there is a shift in subsistence with a greater emphasis on the exploitation of specific local environments. Differences between sub-periods are again marked by changes in material culture and site characteristics. Hunting strategies focus mainly on medium to small game along with continued foraging for plant resources (Collins 1995).

\section{Early Archaic}

According to Collins (1995), the Early Archaic spans from 8800 to 6000 B. P. Early Archaic projectile point styles include Angostura, Early Split Stem, Martindale and Uvalde (Collins 1995). The climate during the Early Archaic is described as drier than the Paleo-Indian period with a return of grasslands (Bousman 1998). Megafauna of the Paleo-Indian period could not subsist in the new ecosystem and gradually died out. With 
the extinction of megafauna, the Early Archaic exploitation of medium to small fauna intensified.

Data recovered from the Wilson-Leonard site reveals the continuation of projectile point forms and the use of small to medium size hearths that were also present during the Paleo-Indian period. The appearance of earth ovens implies another shift in subsistence patterns. Collins (1998) suggests that the earth ovens at Wilson-Leonard were used to cook wild hyacinth along with aquatic and terrestrial resources. Information from Early Archaic human remains from Kerr County (Bement 1991) indicates a diet low in carbohydrates in relation to Early Archaic populations in the Lower Pecos area. Stable-carbon isotopes also suggest a low reliance on $\mathrm{C}_{3}$ plants and animals that consume such vegetation (Johnson and Goode 1994:24).

\section{Middle Archaic}

Date ranges for the Middle Archaic span from 6000 to 4000 B.P. Collins (1995) and Weir (1976) suggest that there was a population increase during this sub-period. Climate was gradually drying as the onset of the Altithermal drought began. Demographic and cultural change likely occurred in response to the hotter and drier conditions. Middle Archaic projectile point styles include Bell, Andice, Calf Creek, Taylor, Nolan, and Travis. Johnson and Goode (1994) postulate that culture transmission from the Lower Pecos region explains the appearance of new point styles in the sub-period.

Middle Archaic subsistence focused on exploitation of resources clustered in riverine environments (Black 1989). The accumulation of burned rock middens during the Middle Archaic reflects this focus on the exploitation of plant resources (Black 1989; Johnson and Goode 1994). Current research has reassessed when the use of burned rock middens intensified. Data from Camp Bowie suggests that intensification occurred in the latter Late Prehistoric period (Mauldin et al. 2003). Little is known about burial practices during this culture period, though a sinkhole in Uvalde County (41UV4) contained 25-50 individuals (Johnson and Goode 1994:28).

\section{Late Archaic}

The Late Archaic is the final sub-period of the Archaic and spans from 4000-1200 B.P. (Collins 2004). The Late Archaic is marked by the introduction of Bulverde, Pedernales, Kinney, Lange, Marshall, Williams, Marcos, Montell, Castroville, Ensor, Frio, Fairland and Darl projectile points. During the early part of the Late Archaic, there are fluctuations in temperature and rainfall. Populations are believed to have increased through this sub-period. This change in climate marks Johnson and Goode's (1994) Late Archaic II (1994).

Some researchers believe that the use of burned rock middens ceased at this time, current research is challenging this notion (Black and Creel 1997; Mauldin et al. 2003). Skeletal evidence from Late Archaic cemeteries in Central and South Texas, suggests the region saw increasing populations that may have prompted the establishment of territorial boundaries resulting in boundary disputes (Nickels et al. 1998). Human remains dating to this sub-period have been found near the Edward's Plateau. Dental evidence shows a high rate of enamel hypoplasia indicating nutritional stress at this time (Johnson and Goode 1994).

\section{Late Prehistoric Period}

This period begins ca. 1200 B. P. (Collins 1995, 2004) and lasts until the Protohistoric Period (ca. 1250 A. D.). The term Late Prehistoric is commonly used to designate the period following the Late Archaic in Central and South Texas. A series of distinctive traits marks the shift from the Archaic to the Late Prehistoric period, including the technological shift to the bow and arrow and the introduction of pottery. The period includes two Phases: The Austin Phase and the Toyah Phase.

At the beginning of this period, environmental conditions were warm and dry. More mesic conditions appear to accelerate after 1000 B.P. (Mauldin and Nickels 2001). Subsistence practices remain relatively unchanged, especially during the Austin Phase. Projectile point styles associated with the Austin Phase include Edwards and Scallorn types while in the Toyah Phase the Perdiz projectile point is prevalent (Collins 1995).

Most researchers agree the early Late Prehistoric sub-period (i.e. Austin Phase) was a time of population decrease (Black 1989:32). Radiocarbon data have revealed that a number of burned rock middens in Central Texas were used long after the Archaic and throughout the Late Prehistoric. Moreover, the "heyday of middenery began after A. D. 1 and peaked during the Late Prehistoric" (Black and Creel 1997:273). Radiocarbon dates from Camp Bowie middens concur with arguments set forth by Black and Creel (1997) that burned rock middens are primarily a Late Prehistoric phenomena (Mauldin et al. 2003).

Beginning rather abruptly at about 650 B.P., a shift in technology occurred. This shift is characterized by the introduction of blade technology, the appearance of the first ceramics in Central Texas (bone-tempered plainwares), 
and the use of Perdiz arrow points and alternately beveled bifaces (Black 1989a:32; Huebner 1991:346). Prewitt (1981) suggests this technology encroached from north-central Texas. Patterson (1988), however, notes the Perdiz point was first seen in southeast Texas by about $1350 \mathrm{BP}$, and was introduced to the west some 600-700 years later.

Ricklis (1995) contends that ceramics became a part of the archaeological record in Central Texas beginning about A. D. 1250/1300. Early ceramics in Central Texas are associated with Toyah Phase components and referred to as Leon Plain. The earliest dates for Leon Plain are relative and based on associations with "Toyah" assemblages. The Leon Plain ceramic type includes undecorated, bone-tempered bowls, jars, and ollas with oxidized, burnished or floated exterior surfaces (Ricklis 1995). Although there is a typical set of attributes associated with Leon Plain, there is notable variation within the type (Black 1986; Johnson 1994; Kalter et al. 2005). This variation is typically attributed to differences in manufacturing methods and cultural affiliation. Stable carbon and nitrogen isotope data suggests that vessels were utilized in the processing of bison bone grease/fat, mesquite bean/bison bone grease and deer/bison bone grease (Quigg et al. 1993).

Huebner (1991) suggests that the sudden return of bison to South and Central Texas during the Late Prehistoric resulted from a xeric climate in the plains north of Texas and increased grass production in the Cross-Timbers and Post Oak Savannah in north-central Texas. Together these formed a "bison corridor" into the South Texas Plain along the eastern edge of the Edwards Plateau (Huebner 1991:354-355). Settlement shifts into rock shelters such as Scorpion Cave in Medina County (Highley et al. 1978) and Classen Rockshelter in northern Bexar County (Fox and Fox 1967) have been noted (Skinner 1981) during this time. Cemeteries from this period often reveal evidence of inter-group conflict (Black 1989:32).

\section{Protohistoric Period}

The transitional period between the Late Prehistoric and Historic period is usually deemed as the Protohistoric period. This period is not well documented and is marked by the end of the Toyah Phase, roughly 1250/1300 A.D. to A. D. 1600/1650 (Hester 1995), and the beginning of Spanish explorations of the area (ca. 1528). The period is concluded with the establishment of a strong Spanish presence in the region in the late 1600 s and early 1700 's. Sporadic encounters between the indigenous populations and Europeans occurred at this time. Identifying this period archaeologically is problematic in that a clear set of material culture associated with this period is lacking. Protohistoric sites may have mixture of Late Prehistoric and Historic artifacts.

\section{Historic Period}

The Historic Period is marked by the arrival of Europeans to the area. In Texas, the first exposure to European contact comes with the arrival of Alva Nuñez Cabeza de Vaca and the remaining survivors of the Narvaez expedition in 1528. Between 1528 and the late 1600s, Spanish excursions into the Texas territory were limited. Europeans did not begin to settle the territory until the beginning of the eighteenth century, and still the inhabitants of the region were mostly Native Americans until the late 1700s.

The first settlement in San Antonio was Mission San Antonio de Valero in 1718. Located at the headwaters of San Pedro Creek, Presidio San Antonio de Bexar was established shortly after to offer protection to the mission inhabitants and recruit Native American converts (Chipman 1992: 117). Within the next fifteen years, San Antonio became the site for four other missions and the Spanish settlement of Villa de Bexar with the arrival of the Canary Islanders. By the late 1700s, San Antonio was a provincial Spanish town thriving in the midst of the harsh Texas frontier.

During the early part of the nineteenth century, New Spain gained its independence as a result of the Napoleonic invasion of its motherland, forming the new nation of Mexico. Mexico enabled the additional settlement of Texas by allowing Anglo settlers, led by Stephen F. Austin, the opportunity to inhabit the region. After the influx of the Anglo settlers, a movement for independence from Mexico was underway by the 1830s. San Antonio played an integral role in the political uprisings that eventually resulted in the Republic of Texas.

The Republic of Texas was incorporated into the United States in 1845. At this point, San Antonio's population became mixed with Anglo, Native, and Hispanic inhabitants. The city boomed with the arrival of the railroad in 1877 , allowing for much easier transportation of people and goods in and out of San Antonio.

\section{History of the Project Area}

The project area was located just to the northeast of the Mission Valero Upper Labors. The Upper Labor Acequia tied into the San Antonio River to the west of Miraflores. The park is located in the lands that were portioned off by Don Juan Antonio Perez de Almazan, Alcade Mayor, in 1731. The project area is located within Range 1, Lots 26 and 27 (Figure 2-1).

Lot 26 was purchased by August Lieck in January of 1852 from the City of San Antonio (BCDR S2:549). Lot 27 was 


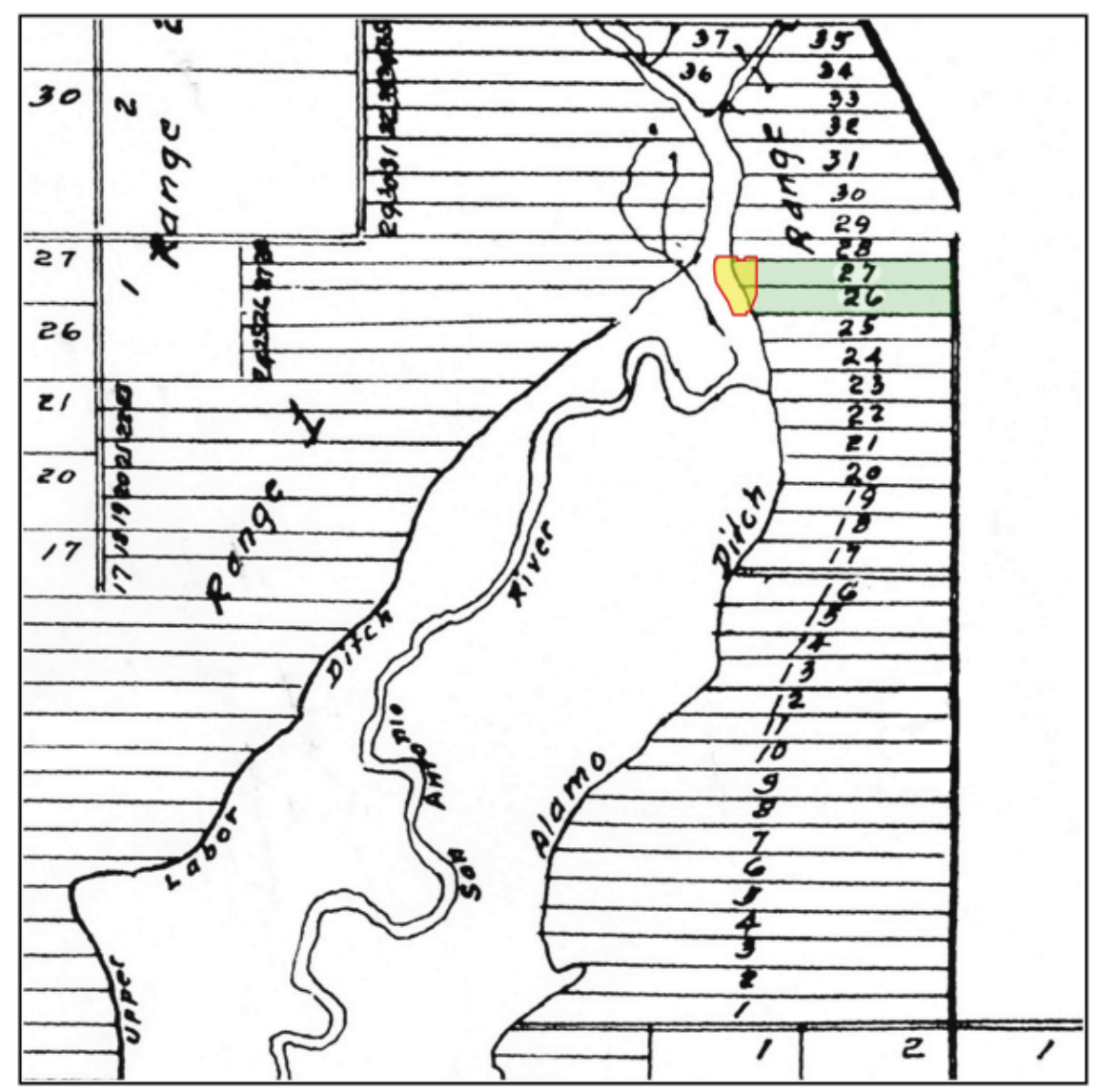

Figure 2-1. Map of the portions of land delineated by Don Juan Antonio Perez de Almazan, Alcade Mayor, in 1731. The Project area is located in Lots 26 and 27 in Range 1 (yellow with red border).

sold to August Lieck by Thomas Devine in 1853 (BCDR L1:166). The property remained in the Lieck family for the remainder of the nineteenth century. In September of 1855, August Lieck conveyed the property to Gottfried Lieck for a sum of $\$ 5000$, along with approximately 400 head of cattle (BCDR O2:123-124). In 1884, Lot 27 was sold to A. J. Fry for a sum of $\$ 12$, to pay for the back taxes of Gottfried Lieck. The deed indicated that Lieck (or his heirs) has two years to reclaim the property and pay the taxes and fees (BCDR 57:487). Richard Jungbecker paid Fry $\$ 65$ to satisfy the fees of the overdue taxes in 1887, therefore effectively gaining control of the entire portion of Lot 26 and 27 from the Lieck heirs (BCDR 57:484). In 1892, R. A. Lieck conveyed portions of the property to his daughter, Theresa Jungbecker, and her husband, Richard Jungbecker (BCDR 116:84). Some disagreement over the division of R.A. Lieck's property occurred within the next couple years. Deed records indicate that a suit between Edmund Lieck and Theresa Jungbecker was settled with Jungbecker receiving an additional portion of Lots 26 and 27 (BCDR 226:281; BCDR 290:121). In 1904, Richard Jungbecker purchased from Julius Lieck the portion of the lots that bordered the San Antonio River
(BCDR 284:386). The property remained in the Jungbecker portion of the Lieck family until 1918. Theresa Z. Jungbecker conveyed the property to Margarita Mercado de Alonso and Guillermo Alonso for a sum of $\$ 11,551.56$ in 1917 (BCDR 544:28). On the same day, Julia Herberer (formerly Jungbecker) sold to the Alonso's her portion of the Lieck property for a sum of $\$ 12,054.87$ (BCDR 544:30). Deed descriptions seem to indicate that the property was owned to both Julia Herberer and Theresa Jungbecker prior to sale to the Alonso's. In March of 1921, Guillermo Alonso entered into to a contract of sale with Aureliano Urrutia, selling the property for $\$ 30,000$ (BCDR 634:268). The warranty deed was executed in May of 1921 (BCDR 638:202).

Dr. Aureliano Urrutia began his garden soon after purchasing the property in 1921. He named the park "Miraflores" and proceeded to transform the place into a tangible reminder of his hometown. The park was initially a garden built to the north of Dr. Urrutia's house. A path from Broadway led to the garden area complete with sculptures and medicinal plants. Originally two structures could be found on the property. A tower located at the southern end of the garden was reminiscent of a windmill (Figure 2-2), possibly built to pay homage to Don Quixote. This building housed Dr. Urrutia's library. The structure is no longer standing, though the footprint was located within the current project area. The second building located on the premises is a guest house Dr. Urrutia dubbed "Quinta Maria" (Figure 2-3). This structure was built in 1923 and was restored by Southwestern Bell in 1981. A recent viewing of the 1939 aerial of the project area reveals a possible footbridge that crosses the San Antonio River and connects into a path that leads to the reflecting pool in the western portion of the project area (Figure 2-4). This footbridge is no longer present.

Urrutia constructed this garden to try to recreate the atmosphere of gardens found in his hometown in Mexico. The location just adjacent to the San Antonio River provided him with a ready water source that played into his design of the park. Urrutia commissioned several artists to produce works displayed in the park. Most notable is Dionicio Rodriquez, an artist from Toluca, Mexico who had perfected a process by which he was able to carve chemically treated concrete to look like wood (Figure 2-5). Several pieces of Rodriguez's work can 
be found in and around Brackenridge Park and are listed on the NRHP. To this day, much of Rodriguez's process remains a secret, and though he had trained assistants, none were able to rival his skill.

Dr. Urrutia's garden exhibited his eclectic style that was prominent at his home as well. The garden served as a private retreat that Urrutia visited every morning to swim laps in one of the large pools fed by an Artesian well. The garden was also used to entertain Dr. Urrutia's expansive family and myriad of friends (Westkaemper 1985).

In 1962, the garden was sold to United States Automobile Association (USAA), who built an 8-story office building and parking lot on the eastern portion of the garden property. In 1974, Southwestern Bell purchased the property, turning the remaining portion of the garden into recreation area to be used by the Telephone Pioneers (employees who had been with the company for more than eighteen years). The Pioneers constructed two connected open-air pavilions on the southern portion of the property. In addition to the pavilions, the Pioneers placed 23 picnic tables around the park. In 2001, the Miraflores portion of the property was transferred to The University of the Incarnate Word, who later conveyed it to the City of San Antonio.

The University decided to turn the property into a parking lot and soon began the process to get approval.

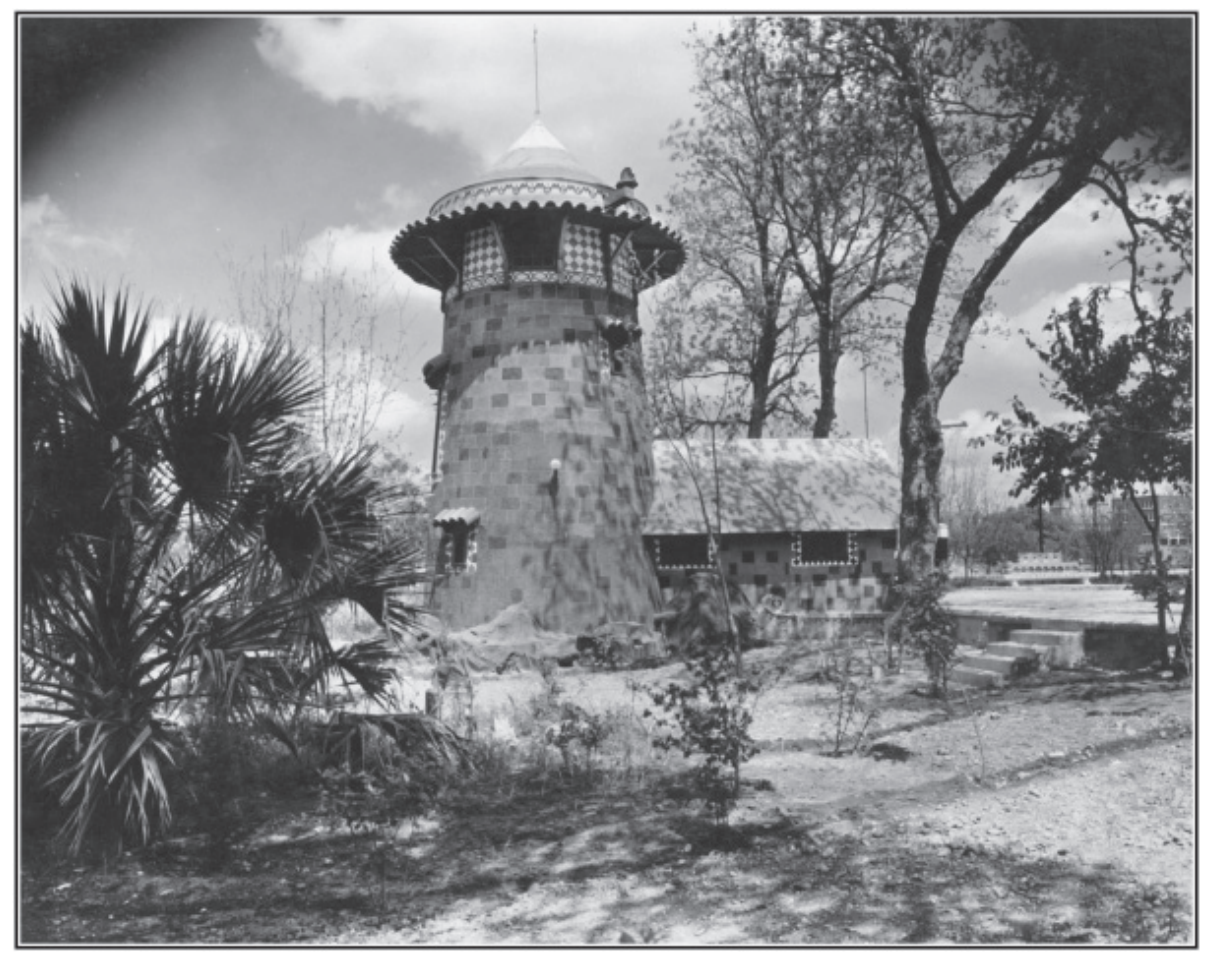

Figure 2-2. Photograph of the library tower ca. 1930.

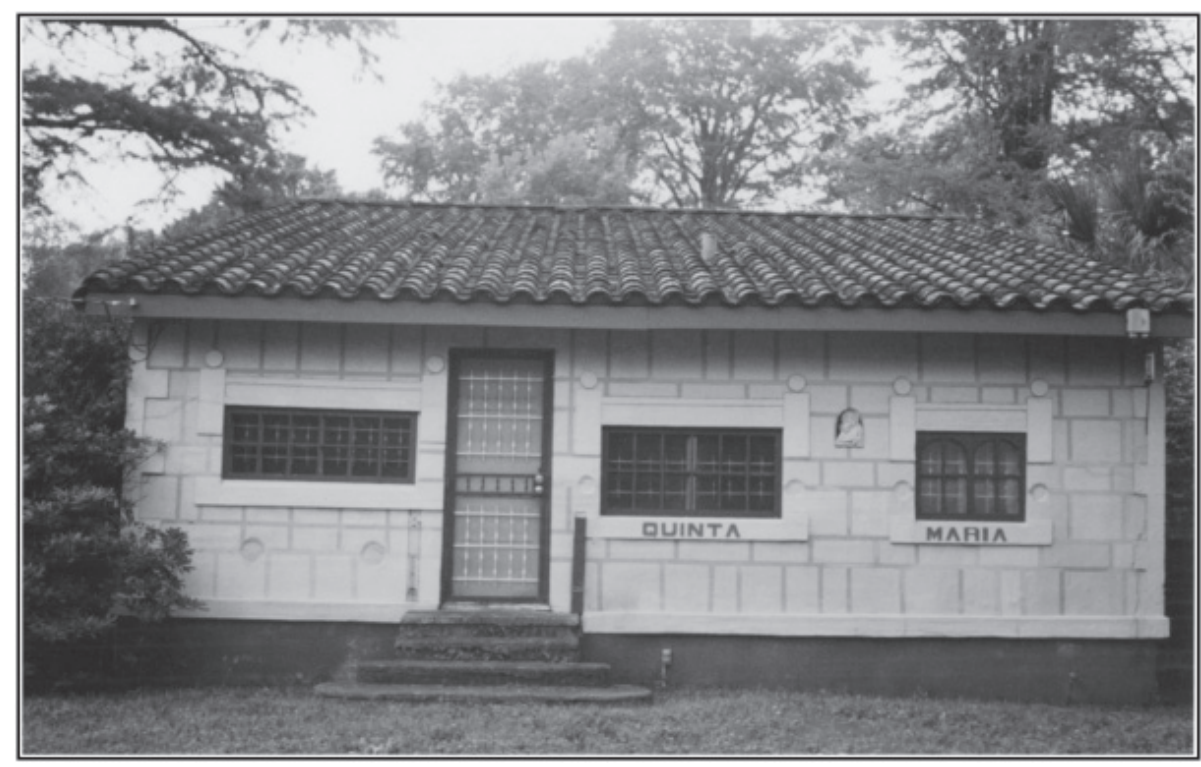

Figure 2-3. Photograph of Quinta Maria.
Antonio found that a portion of Miraflores remained as part of the King of Spain grant. Over the years, the portion of land was assumed to be part of the Lieck/Jungbecker property and was sold to Urrutia as such. When the City became aware of the discrepancy, they entered into a suit against the University of the Incarnate Word and SBC to gain back ownership (Cause No. 2003-CI-01943). The parties settled out of court in July of 2005, and the property reverted to the City of San Antonio (Ordinance 100961).

Six works by Rodriguez remain within the park. The large fountain he constructed was demolished in 2001. The tile and bronze gate that marked the entrance from Broadway was relocated the San Antonio Museum of Art in 2001 (Figure 


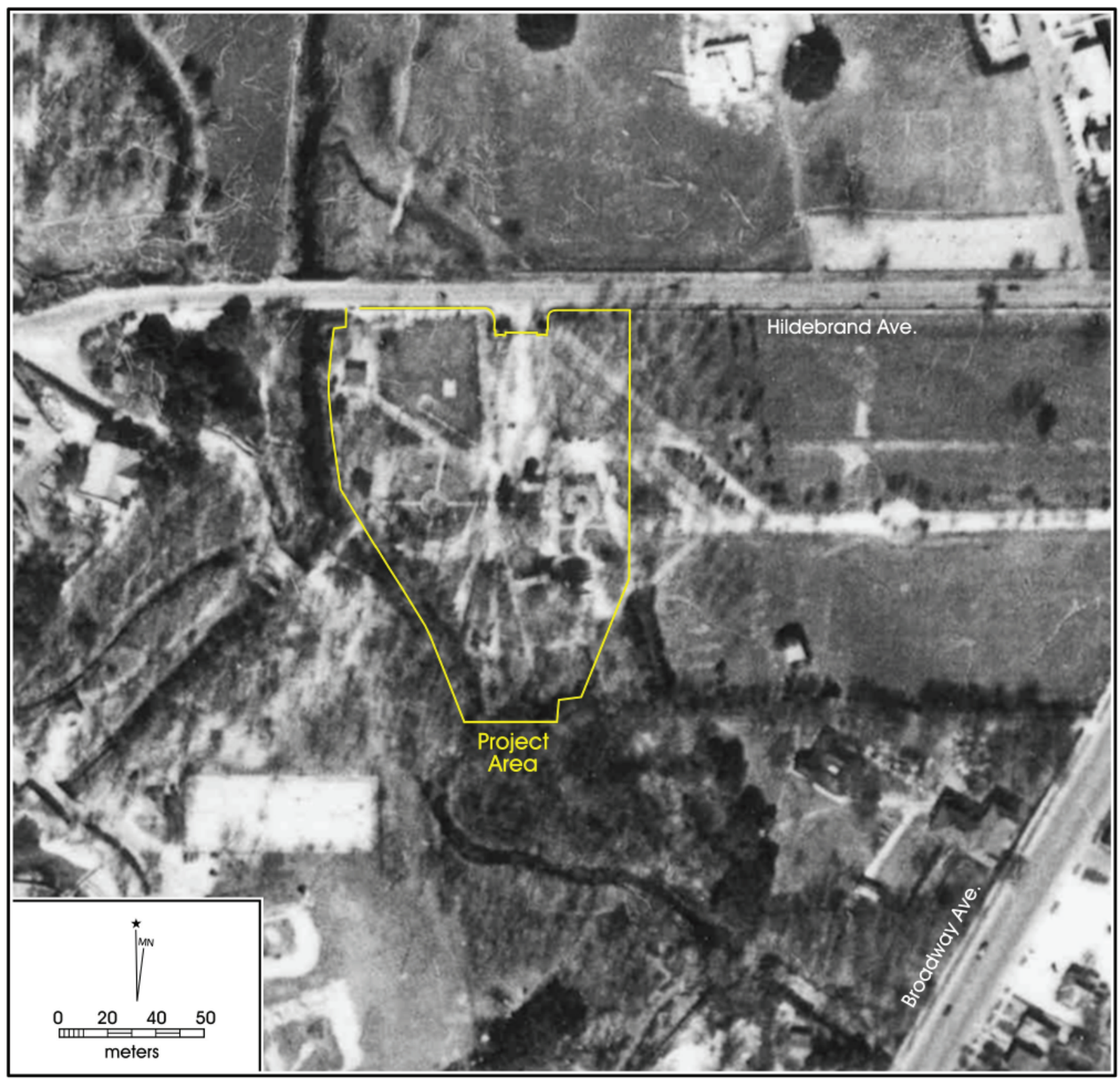

Figure 2-4. Location of the project area on the 1939 aerial.

2-6). This was the second time the gate had been moved, the first time occurring in 1962 when USAA built the 8-story building. A small bench was given to the Witte Museum in 1974. The remaining pieces compose one of the most intact groupings of Rodriguez's work, as well as examples of his earliest sculptures in the United States.

\section{Previous Archaeological Investigations}

Within an approximate half-mile radius, there are 18 archaeological sites. Of these 18 sites, seven are historic, seven are prehistoric, and four are multi-component sites. To the immediate north of the project area, across Hildebrand Ave, a large portion of the grounds of the University of the Incarnate Word is part of the Headwaters of the San Antonio River National Register District. Many prehistoric and historic sites are located within this property. Also within the half-mile radius are several historic structures such as the Sweet House (Fernridge), the Ruiz House, and the Navarro House. The later two had been removed from the original locations and are now on the grounds of the Witte Museum.

Several archaeological surveys of the area have occurred since the early 1970s, though not early enough to fully document 


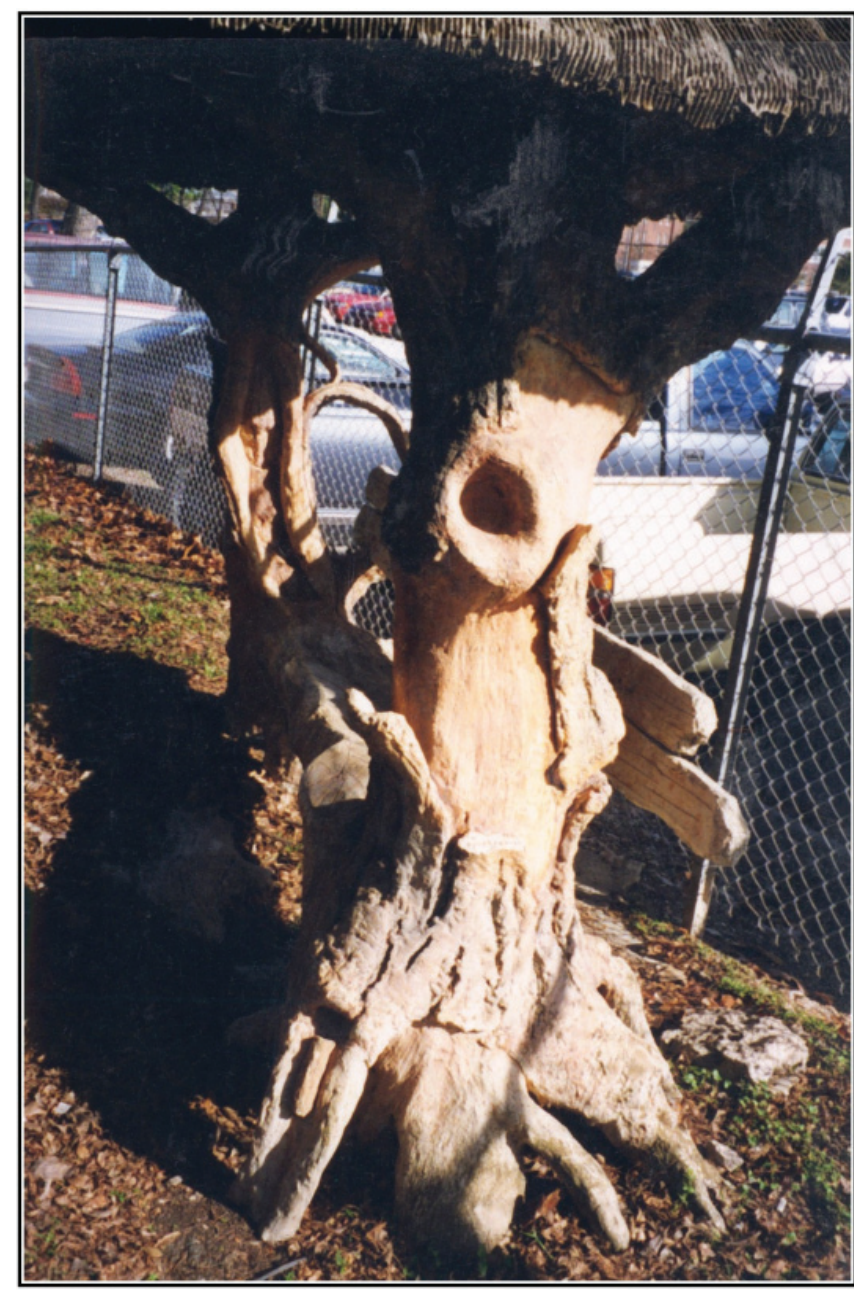

Figure 2-5. Photograph of bench created by Dionicio Rodriguez.

many sites that were destroyed due to the construction of Olmos Dam. Amateur archaeologist, C.D. Orchard recorded locations of sites and collected artifacts during the 1920s and 30s. Orchard published much of his findings during the 1960s and 70s (Fox 1975; 3). More in depth discussions of the previous excavations in the area can be found in Stothert (1989), Cox et al. (1999), Miller et al. (1999), and Houk and Miller (2001).

Professional archaeological excavations were conducted near the current project area by the Center for Archaeological Research in 1975 (Fox 1975). This survey focused on documenting recorded and reported sites on the grounds of Incarnated Word College (known today as the University of the Incarnate Word). During the course of the project, twelve recorded sites were visited: 41BX289, 41BX282, 41BX283, 41BX284, 41BX285, 41BX286, 41BX287, 41BX288, 41BX24, 41BX290, 41BX291, and 41BX292. In addition to the twelve sites, Orchard identified the location of five areas

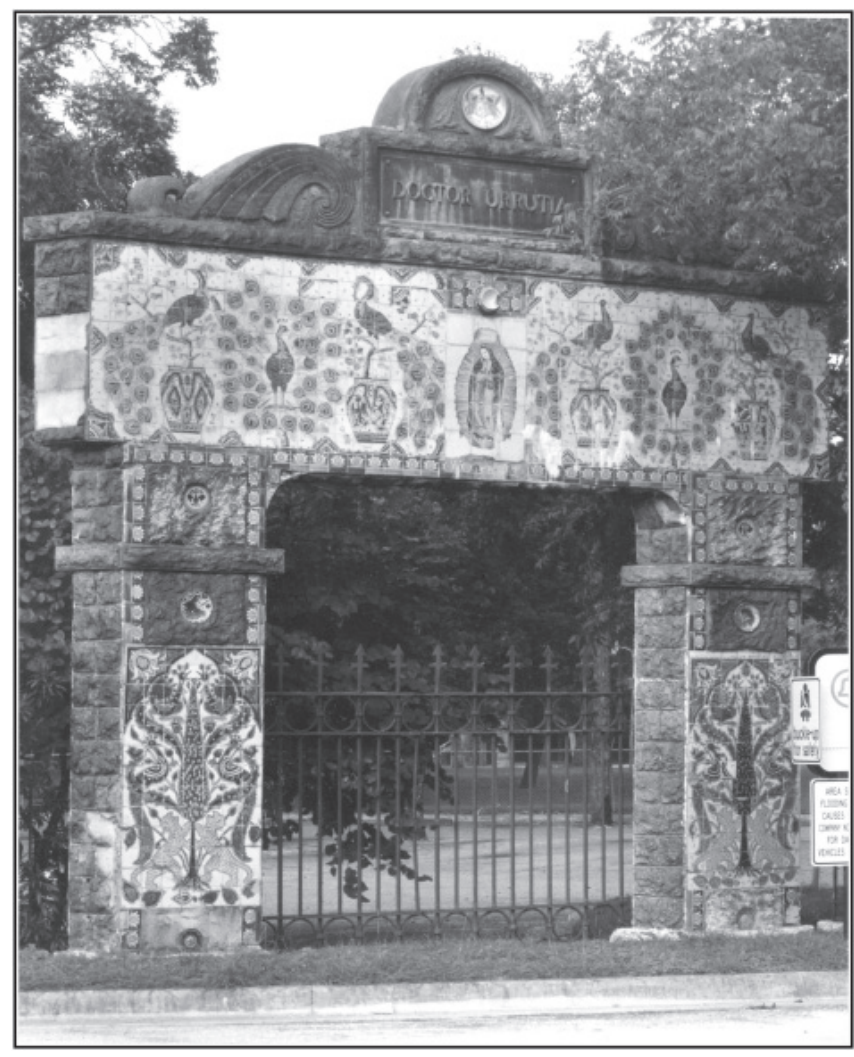

Figure 2-6. Photograph of the gate that was located on Broadway before being relocated to the San Antonio Museum of Art.

that had contained cultural remains prior to the construction activities at the Olmos Dam and Incarnate Word. These sites were not issued trinomials, but their locations were recorded on a sketch map of the area. Of the twelve sites recorded, eleven are located within a half mile radius of the current project area. Site $41 \mathrm{BX} 288$ is a prehistoric open campsite consisting of a scatter of burned rock and chert flakes. Site 41BX290 is a prehistoric open campsite characterized by the presence of burned rock, cores, and chert flakes. Site 41BX291 is a prehistoric open campsite that produced cores, debitage, and biface fragments, as well as a few historic artifacts. Site 41BX292 is a prehistoric open campsite exhibiting cores, debitage, burned rock, and biface fragments.

Near Olmos Dam, a number of prehistoric middens was identified and designated as 41BX24. The site is an open camp with a large midden, which produced faunal remains, debitage, scrapers, gouges, and fragments of projectile points, as well as a couple fragments of historic ceramics. The site is approximately 250 meters in diameter and is suspected to extend to the southern end of a crescent mound observed by Orchard and Campbell (1960: 457-458). The majority of the site has been disturbed (Fox 1975: 8). 
Site 41BX283 is a historic quarry located on the University of the Incarnate Word grounds. The quarry is rumored to have been first used during the Colonial Period, though no artifacts were noted to support the claim. The quarry doesn't appear to have been used prior to 1890 , and it was abandoned by 1938 . On the site, a metal frame bridge was located and recommended for preservation (Fox 1975: 4).

Also located on the University of the Incarnate Word grounds during the 1975 survey is 41BX285. This site consists of the remains of a stone foundation. There were likely several structures present at the site. C. D. Orchard recalled that he helped to tear down several rock houses in that location during the early 1900s. The stone foundation at the time of the recording of the site was partially obscured by a trash dump.

Site 41BX282, the San Antonio Springs (the Blue Hole), consists of an unidentified metal structure and pipes, as well as a concrete casing around the top of a natural spring located on the University of the Incarnate Word grounds. The spring is at the headwaters of the San Antonio River, west of Brackenridge Villa. The surrounding land was likely used as a campground prior to European contact, though the periodic flooding has washed away evidence of this type of occupation. Historic military encampments were located in the vicinity of the springs during the early $19^{\text {th }}$ century according to historical records, though no cultural remains dating to this period have been located at the site (Fox 1975: 4).

Site 41BX284 is a cut-stone structure across an un-named tributary of the San Antonio River on the grounds of the University of the Incarnate Word. According to local tradition, the structure was part of a mill, though the building would be considered very small at 18 feet across, and the flow of the tributary would not provide enough energy.

Site $41 \mathrm{BX} 287$ is a possible historic dump located on the University of the Incarnate Word grounds. No sign of house remains is present at the site, but the dump contained glass, ceramic, burned rock, bricks, and metal fragments. The majority of the artifacts indicate a late $19^{\text {th }}$ century temporal affiliation.

Site 41BX289, also known as Fernridge, is a historic house located on the ground of the University of the Incarnate Word. The property was purchased by J. R. Sweet who constructed the east wing in 1852. George W. Brackenridge later purchased Sweet's holdings and built a three story addition to the structure in 1886. Each building episode is typical of the styles of the period. Brackenridge offered the City the Sweet property, along with his other holdings which totaled 217 acres, for a sum of $\$ 50,000$ in 1872 . The city considered the offer for approximately two years before finally rejecting it due to the inability to negotiate a better price (Dunn 1975). In 1897, the Sisters of Charity of the Incarnate Word petitioned Brackenridge to sell them the parcel of land that contained the Fernridge structure. Brackenridge agreed, but only under the condition that they purchase his entire holdings, approximately 300 acres, for the sum of $\$ 125,000$. This was an amazing sum of money to the order, but they accepted and utilized Ferniidge as the convent until they were able to construct the Mother House (Ramsdell 1959; 213). Today, the structure is known as Brackenridge Villa, and is used by the University as meeting space.

In 1976, the Incarnate Word College Archaeological Field School conducted test excavations at 41BX291. The field school ran for 23 days during July and August. Ten $2 \times 2$ meter units were set up and two backhoe trenches were excavated. The excavations indicated that it is a multi-component site with two major occupation episodes. The earlier episode dates to the Terminal Archaic Period (ca. 1750-1250 BP) and the later dates to the Late Prehistoric Period (ca. 1250200 BP). Both occupations of the site were characterized by artifacts relating to short-term, repeated, hunting and gathering activities (Katz and Katz 1982).

During the last few weeks of December 1976, the Center for Archaeological Research conducted an archaeological and historical survey within the boundaries of Brackenridge Park. Four prehistoric sites were recorded over the course of the survey. These included 41BX321, 41BX322, 41BX264, and 41BX323. Site 41BX323, known as the Paddle Boat Site, is located within a half mile radius of the current project area. The site exhibits a prehistoric component with debitage, burned rock, and a projectile point. The prehistoric component of the site was recorded as being "Neo-American" or Late Prehistoric in age. Recent excavations produced Leon Plain ware pottery from the upper levels of deposits. Site 41BX264, also located within a half mile of the current project area, is a prehistoric lithic scatter that may have contained a burned rock midden. The construction of the Polo Field at Brackenridge Park likely destroyed the majority of the site. The area has been leveled and covered with grass, though there is a possibility that parts of the site remain. Artifacts noted included cores, flakes, choppers, scrappers, burned rock, bifacial blanks and several projectile points indicating an Early to Middle Archaic period. All four of the identified sites were partially destroyed and were deemed to be in danger of further destruction at the time of the survey in 1976. In addition to the recorded sites, eleven "collection localities" were noted that contained prehistoric material but not enough to warrant a site designation. 
Additional archaeological work on the grounds of the University of the Incarnate Word encountered 41BX261, a multi-component site. The prehistoric portion of the site is a possible lithic workshop dating to the Late Archaic. Artifacts encountered relating to the prehistoric period included biface fragments, chert flakes, blanks, pre-forms, cores, a fragment of Leon Plain ware, and two Late Archaic projectile points. The historic component of the site is a dump, possibly dating to the $1880 \mathrm{~s}$, that contained fragments of glass, metal, and historic ceramics (Stothert 1989: 82; THC 2007).

In June 1977, the Center for Archaeological Research conducted a pedestrian survey in the vicinity of Olmos Dam. The survey was conducted to evaluate the cultural deposit that might be affected by two proposed alternate roads through the Olmos Basin. It was recommended that archaeological testing occur along the proposed routes (Brown 1977).

During November of 1977, the Center for Archaeological Research conducted archaeological testing just south of the Olmos Dam at 41BX291. The project resulted with the delineation of the northern boundary of the site, which extended north of the Incarnate Word property into the Olmos Dam right-of-way. The site produced Paleo-Indian through European-aged deposits.

The Center for Archaeological Research conducted archaeological investigations at portions of 41BX1 during December 1979 to May 1980. The project consisted of the excavation of backhoe trenches, block excavations, and documentation of in situ burials. Excavations revealed Middle Archaic and Late Archaic components, with one Paleo-Indian point recovered from one excavation area. The excavation of the burials provided much information on the people and burial practices of the Late Archaic Period (Lukowski 1988).

In October of 1997 and March of 1998, SWCA, Inc. Environmental Consultants conducted cultural resource investigations within Brackenridge Park. The purpose of the project was to test 41BX323 and investigate the Second Waterworks Canal prior to the installation of a proposed pipeline. SWCA recommended that 41BX323 be avoided or construction impacts mitigated because it had the potential for producing information concerning the paleoenvironment, prehistoric technology and subsistence patterns of the region. Also, because the proposed pipeline was to cross a portion of the Upper Labor Acequia further investigations were recommended in that area. Cultural materials recovered during the SWCA investigation included lithic debitage and tools, ceramics, and faunal remains (Miller et al. 1999).
SWCA returned to 41BX323 in the fall and winter of 1998 to conduct additional archaeological excavations. Excavations were carried out along the proposed pipeline footprint. The investigation produced Archaic deposits with intact burned rock features, and a shallow Late Prehistoric deposit along one terrace location. The cultural deposits at the site appear to date primarily to the Early Archaic, with evidence of occupation in the Late and Transitional Archaic periods.

In 2001, SWCA returned to Brackenridge Park to conduct a survey of a portion of the park that was to be rehabilitated. The survey was conducted along 28.3 acres of Brackenridge Park. The western portion of the survey focused on 41BX323. Much of the site produced sparse cultural materials, though a concentration of burned rock, debitage and mussel shell was located along one section. The potential for the site to produce additional information about the prehistoric occupation of the area was once more recognized. Again, 41BX323 was recommended for further testing if impacts were to occur within the site boundaries. In addition to visiting 41BX323, a previous unrecorded site was located along the eastern portion of the project area. Site 41BX1425 was identified as a prehistoric campsite, with a Transitional Archaic and historic component. The prehistoric component consists of an Ensor point, burned rock, and debitage. The historic component is at or near the surface, and consists of historic ceramics, glass fragments, and metal objects that date to the $19^{\text {th }}$ and $20^{\text {th }}$ centuries (Houk and Miller 2001).

In September 2007, CAR conducted archaeological investigations consisting of pedestrian survey and controlled excavation of test units and trenched. Two components were noted during the investigations along the eastern margin of the site. One component is Late Prehistoric in age, while the deeper deposit may be Early Archaic, though not enough evidence was produced that would positively assign it to this time period (Figueroa and Dowling n.d.).

Site 41BX170 is a historic site consisting of the outline of a lime kiln and remnants of stone foundations. Historic artifacts including fragments of a large ceramic pot and glass were noted when the site was recorded in 1994 (THC 2007).

In 1996, a portion of the Upper Labor Acequia was exposed in Brackenridge Park prompting the Parks and Recreation Department of the City of San Antonio to contract with CAR to investigate the feature. During the course of the investigation, 41BX1273 was identified and documented. This site is the location of the Upper Labor Dam, a dam constructed of limestone blocks in 1776 by the Spanish colonists to divert water from the river to the Upper Labor Acequia. The dam was modified during the $19^{\text {th }}$ century with dressed stone and 
set at a slightly different angle. A prehistoric component was also revealed during the investigation, located approximately $120 \mathrm{~cm}$ below the current surface (Cox et al 1999). The prehistoric component consisted of lithic debitage. 


\section{Chapter 3: Archaeological Field and Laboratory Methods}

\section{Archaeological Testing Methods}

Prior to testing, CAR has reviewed historic aerials and maps of the project area as well as the NHRP nomination form, historic photographs, and the Westkaemper thesis (1985) to gain insight as to the layout and possible architectural features at the site. To prepare for the fieldwork, CAR laid out a 10 meter by 10 meter grid over the entire project area. Next, CAR staff excavated shovel tests at 10 meter intervals to determine the extent of the buried cultural remains (Figure 3-1). Prior to the fieldwork, it was estimated that approximately 176 shovel tests would be excavated within the project area. That actual number was lower because large sections of the park could not be tested due to standing water.

Shovel tests where $30 \mathrm{~cm}$ in diameter, and unless prevented by obstacles or buried architectural features, extended to a depth of $60 \mathrm{~cm}$. Shovel tests were excavated in $10-\mathrm{cm}$ increments, and all soil from each level was screened through 1/4-inch hardware cloth. Shovel tests that encountered remnants of architectural features were terminated, and did not extend below the feature. All encountered artifacts were collected with appropriate provenience recorded for laboratory processing, analysis, and curation. A shovel test form was completed for every excavated shovel test. Data collected from each shovel test included the final excavation depth, a tally of all materials recovered from each 10$\mathrm{cm}$ level, and a brief soil description (texture, consistence, Munsell color, inclusions). A profile sketch was included on the data recovery form if warranted. The location of every shovel test was recorded with Sokia SET 6E Total Data Station. Shovel test locations were sketched onto a topographic map as a backup. Any additional observations considered pertinent have been included as comments on the standard shovel test form. All artifacts and documentation pertaining to the project are curated at the CAR facility.

Shovel tests often did not allow sufficient horizontal exposure to identify the nature of features exposed. Therefore once the extent of the modern fill became evident, several handexcavated test units and trenches were dug within the project area in effort to locate potential features and enlarge shovel

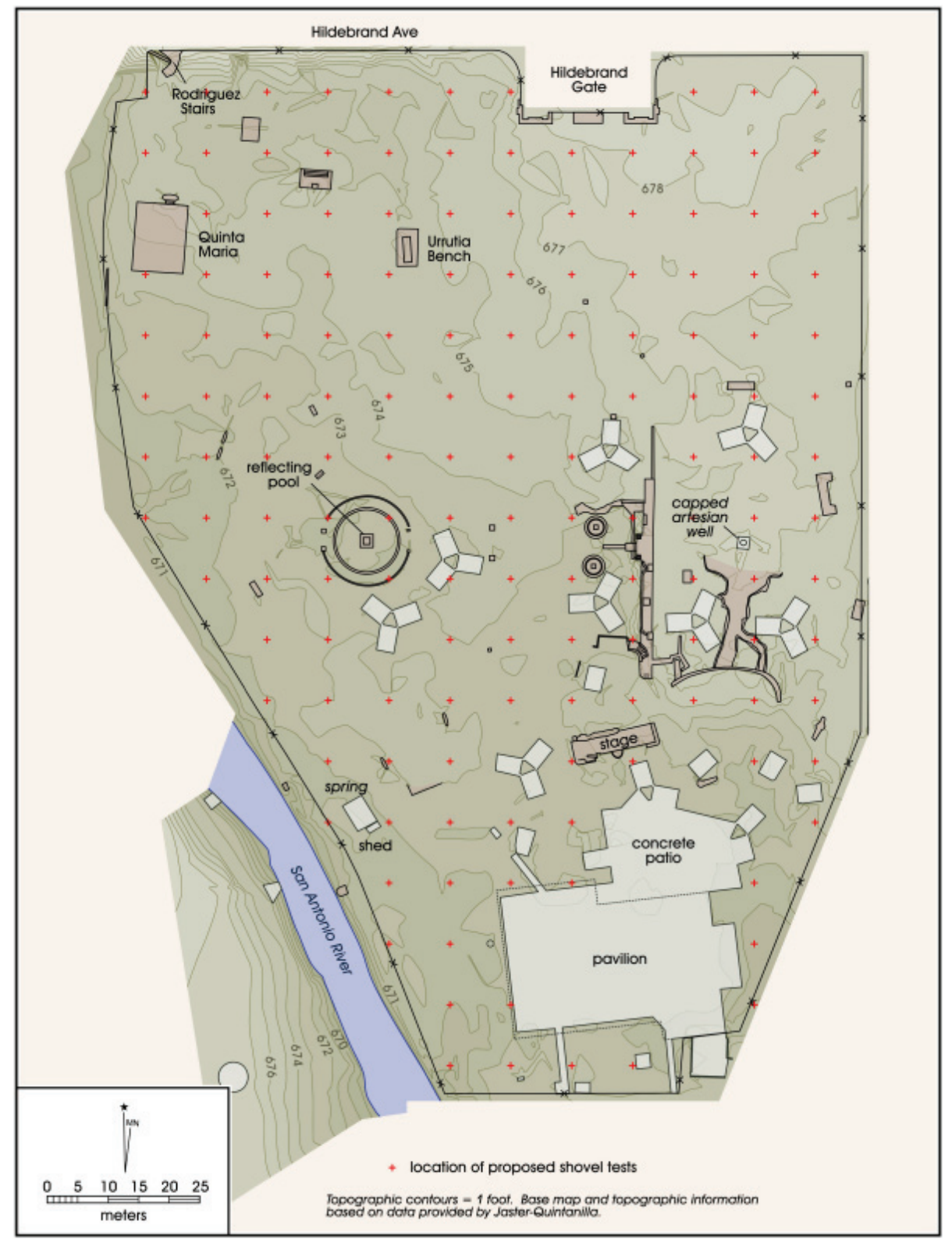

Figure 3-1. Map of the project area showing the location of the proposed shovel tests. 
tests to more fully expose encountered features. A total of five test units were excavated throughout the project area. Two were located in the vicinity of the reflecting pool to determine the nature and depth of the feature. One of these test units was $50 \times 50 \mathrm{~cm}$, located at the edge of the pool basin. The other test unit was $50 \times 100 \mathrm{~cm}$, and spanned the concrete border that separated the pathway and the exterior of the feature. An additional three test units were excavated in the northeast portion of the site to investigate a concentration of prehistoric materials. All units were excavated in $10 \mathrm{~cm}$ arbitrary levels and the matrix was screen through 1/4-inch hardware cloth. Artifacts were collected and bagged with appropriate information.

A total of four trenches were excavated within the park. Each trench ranged in dimensions and depth, conditioned by the size and the depth of the feature being pursued. The matrix was not screened and the trenches were not excavated in 10 $\mathrm{cm}$ levels due to the modern age of the fill. Nonetheless, excavators inspected the soil as it was removed to see if it contained any cultural material.

In addition to the shovel testing, the SOW proposed 1-2 backhoe trenches to be excavated in areas that will be deeply impacted by the placement of the pedestrian bridge. Due to the high water table near the bank of the San Antonio River, backhoe trenching is not possible. Instead, coring of the areas that would potentially include the footers of the pedestrian bridge was the method used to test the areas that would be disturbed. One core was excavated at the proposed location of the footings of the pedestrian bridge within the project area. The core was excavated using a metal pipe with a
PVC pipe sleeve. The pipe was hammered into the ground and the PVC pipe sleeve collected the sample. The core was approximately 1.8 meters in depth. The core was extracted in $90 \mathrm{~cm}$ increments and returned to the lab. The PVC pipe was slit to view the sample and observe the sediment layers, checking for cultural material. Pollen samples were sent off to determine if there was good preservation. If the samples come back showing that pollen preservation is good, then a mechanical core will be taken for further pollen analysis.

\section{Archaeological Laboratory Methods}

All cultural materials and records obtained and/or generated during the project were prepared in accordance with federal regulation 36 CFR part 79, and THC requirements for State Held-in-Trust collections. Additionally, the materials were curated in accordance with current guidelines of the CAR. Artifacts processed in the CAR laboratory were washed, airdried, and stored in 4-mm zip locking archival-quality bags. Acid-free labels were placed in all artifact bags. Each label contained provenience information and a corresponding lot number written in archival ink, with pencil or laser printed. Tools and ceramics were labeled with permanent ink over a clear coat of acrylic and covered by another acrylic coat. In addition, a small sample of unmodified debitage from each lot was labeled with the appropriate provenience data. Artifacts are separated by class and stored in acid-free boxes. Digital photographs were printed on acid-free paper, labeled with archivally appropriate materials, and placed in archivalquality sleeves. All field forms were completed with pencil. Upon completion of the project, all collected materials will be housed at CAR. 


\section{Chapter 4: Results of Investigations}

Testing of the Miraflores Park occurred during September and October of 2007. Due to the overall wet spring and summer, the water table was reached in nearly every shovel test excavated within the park. However, the depth of the water table varied around the site. In lower lying areas, water was encountered at about 20-30 $\mathrm{cm}$ below the surface (cmbs). In higher portions of the tract, shovel tests encountered water between 55 and $60 \mathrm{cmbs}$. In general, the water table is very shallow in the western half of the tract as one moves closer to the stream channel and slightly deeper along the eastern portion. The area immediately south of the stage and the area in the vicinity of the capped fountain are exceptions to this pattern. In these areas of the eastern half of the park, the water table is relatively shallow (20-30 cmbs).

A total of 122 shovel tests, four handexcavated trenches, and five test units were excavated during the course of the project. Figure 4-1 shows the locations of these excavations and the preliminary interpretations derived from them. Because of the small size of some of the exposures, particularly within the STs, some of the interpretations remain preliminary until larger areas of buried features can be exposed either through additional archaeology and/or during construction monitoring.

\section{Results of the Shovel Tests}

During the course of the fieldwork, 122 shovel tests (STs) were excavated within portions of the project area that were not waterlogged. Prior to the commencement of the fieldwork, San Antonio experienced one of the wettest months on record. As a result, a large portion of the project area was underwater due to flooding of the San Antonio River. Fieldwork began when the river receded and Miraflores the project area.
Park began to dry out. Natural springs began flowing within the project area and prevented the investigation of certain portions of the site. The northwest portion of Miraflores was the main area that was not tested, and it may not be feasible to test it until the springs stop flowing. The following discussion of the shovel test groups shovel tests together based on proximity and/or similarity in artifact content, or because of their relation to a feature.

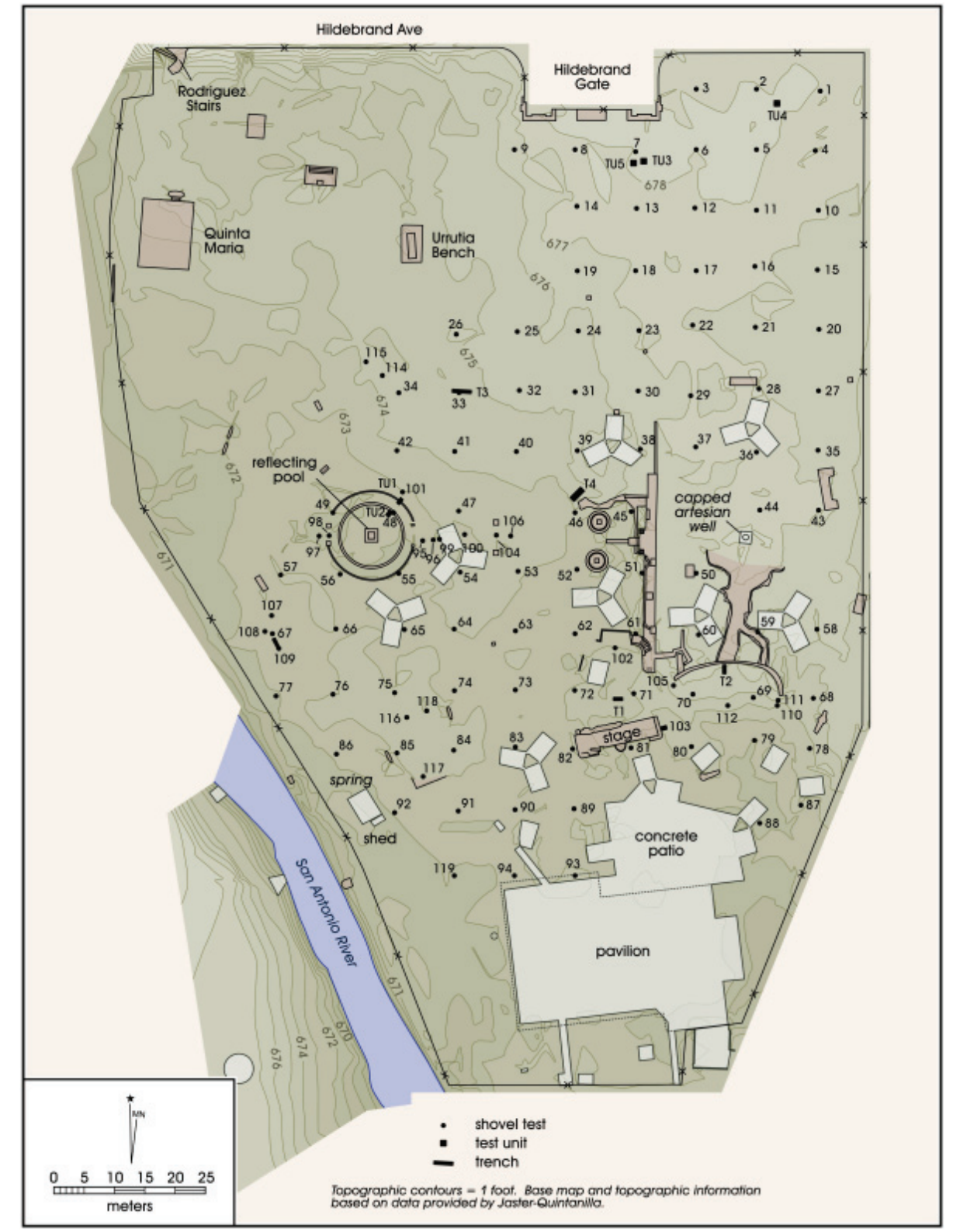

Figure 4-1. Map of the location of the shovel tests, units and trenches excavated within 
STs situated in the northeast corner of the park (STs 1-5), at the highest elevation within the tract (Figure 4-1), consistently identified prehistoric materials (Table 4-1). These materials appear to be in situ and are not disturbed. The prehistoric material begins very near the modern surface and extends to the bottom of the $60 \mathrm{~cm}$ shovel tests. The historic material encountered in these shovel tests, consisting of glass, ceramic, concrete, metal, and brick, was confined to the upper levels. Prehistoric materials, consisting of debitage, burned rock, bone, and charcoal, were recovered from the lower levels of the shovel tests.

Table 4-1. Results of Shovel Test 1 through 5

\begin{tabular}{|c|c|c|c|c|c|}
\hline Unit & level & $\begin{array}{l}\text { Artifact } \\
\text { Category }\end{array}$ & description & count & $\begin{array}{l}\text { weight } \\
\text { (g) }\end{array}$ \\
\hline \multirow{3}{*}{ ST 01} & 4 & Glass & Chimney & 1 & 0 \\
\hline & \multirow{2}{*}{6} & Burned rock & & 5 & 13.9 \\
\hline & & Debitage & & 12 & 0 \\
\hline \multirow{9}{*}{ ST 02} & \multirow{2}{*}{1} & Glass & Brown & 1 & 0 \\
\hline & & Metal & Unidentified & 1 & 0 \\
\hline & \multirow{2}{*}{2} & Bone & & 1 & 1.1 \\
\hline & & Burned rock & & 1 & 146 \\
\hline & \multirow{2}{*}{3} & Bone & & 1 & 0.1 \\
\hline & & Burned rock & & 2 & 3.7 \\
\hline & 4 & Burned rock & & 1 & 1 \\
\hline & & Bone & & 1 & 1.2 \\
\hline & 6 & \begin{tabular}{|l|} 
Charcoal and \\
macrobotanical
\end{tabular} & & 1 & 0 \\
\hline \multirow{3}{*}{ ST 03} & 3 & Debitage & & 1 & 0 \\
\hline & 4 & Burned rock & & 3 & 111 \\
\hline & 5 & Debitage & & 1 & 0 \\
\hline \multirow{11}{*}{ ST 04} & 1 & Plastics & & 1 & 0 \\
\hline & \multirow{6}{*}{3} & Brick & & 3 & 0 \\
\hline & & Burned rock & & 1 & 0.4 \\
\hline & & Cement & & 1 & 0 \\
\hline & & \begin{tabular}{|l|} 
Charcoal and \\
macrobotanical \\
\end{tabular} & & 1 & 0 \\
\hline & & \begin{tabular}{|l|} 
Metal \\
\end{tabular} & Wire Nail & 2 & 0 \\
\hline & & Tile & & 1 & 0 \\
\hline & \multirow{3}{*}{4} & Bldg Rock & & 1 & 119.6 \\
\hline & & Burned rock & & 4 & 16.8 \\
\hline & & Limestone & & 1 & 128.1 \\
\hline & 5 & Burned rock & & 3 & 113.5 \\
\hline \multirow{4}{*}{ ST 05} & \multirow{2}{*}{2} & Debitage & & 2 & 0 \\
\hline & & Tile & & 2 & 0 \\
\hline & 3 & Debitage & & 1 & 0 \\
\hline & 5 & Burned rock & & 1 & 24.1 \\
\hline
\end{tabular}

Shovel Tests 6, 7, 8, 11, 12 13, and 14 (Figure 4-1) produced a variety of historic artifacts (Table 4-2). Cut bone, glass (clear, purple, and brown), metal fragments, nails, slate, brick, and cement were recovered from these shovel tests. Shovel Tests 7, 8, 12 and 13 also produced lithic debitage and burned rock mixed in with the historic artifacts. The location of these six shovel tests and the type of artifacts recovered indicated that there may be a historic trash pit or scattering within the area. The 1939 aerial reveals what appears to be a path leading from the Hildebrand entrance to the library. However, none of these shovel tests along this alignment exposed such a feature. This suggest that the area immediately south of the Hildebrand entrance may have been graded and subsequently filled in with soil containing historic material.

Table 4-2. Results of Shovel Tests 6, 7, 8, 11, 12 and 13

\begin{tabular}{|c|c|c|c|c|c|}
\hline Unit & level & $\begin{array}{c}\text { Artifact } \\
\text { Category }\end{array}$ & description & count & $\begin{array}{c}\text { weight } \\
\text { (g) }\end{array}$ \\
\hline \multirow{9}{*}{ ST 06} & 1 & Flagstone & & 1 & 0 \\
\hline & \multirow{2}{*}{2} & Asbestos tile & & 1 & 1.4 \\
\hline & & Mortar & & 1 & 0 \\
\hline & \multirow{6}{*}{3} & Asphalt & & 1 & 4.8 \\
\hline & & Burned rock & & 2 & 48.6 \\
\hline & & Unknown & & 1 & 0.3 \\
\hline & & Mortar & & 4 & 0 \\
\hline & & Cement & & 5 & 0 \\
\hline & & Ceramics & Porcelain & 1 & 0 \\
\hline \multirow{17}{*}{ ST 07} & \multirow{2}{*}{1} & Plastics & & 2 & 0 \\
\hline & & Ceramics & Stoneware & 1 & 0 \\
\hline & \multirow{7}{*}{2} & Glass & Brown & 1 & 0 \\
\hline & & Debitage & & 1 & 0 \\
\hline & & Bone & & 1 & 17 \\
\hline & & Metal & Wire Nail & 3 & 0 \\
\hline & & Tile w/cement & & 1 & 0 \\
\hline & & Charcoal and & & 3 & 0 \\
\hline & & Glass & Chimney & 1 & 0 \\
\hline & \multirow{3}{*}{3} & Charcoal and & & 3 & 0 \\
\hline & & Bone & & 1 & 4 \\
\hline & & \begin{tabular}{|l} 
Burned \\
Cement
\end{tabular} & & 6 & 0 \\
\hline & \multirow{5}{*}{4} & Bone & & 1 & 2.3 \\
\hline & & \multirow{3}{*}{ Glass } & Brown & 2 & 0 \\
\hline & & & Clear & 1 & 0 \\
\hline & & & Aqua & 1 & 0 \\
\hline & & Charcoal and & & 2 & 0 \\
\hline \multirow{5}{*}{ ST 08} & \multirow{2}{*}{2} & \multirow{2}{*}{ Glass } & Clear & 1 & 0 \\
\hline & & & Brown & 1 & 0 \\
\hline & \multirow{2}{*}{3} & Plastics & Tire valve cap & 1 & 0 \\
\hline & & Brick & & 1 & 0 \\
\hline & 4 & Debitage & & 1 & 0 \\
\hline
\end{tabular}


Table 4-2. Continued...

\begin{tabular}{|c|c|c|c|c|c|}
\hline Unit & level & $\begin{array}{c}\text { Artifact } \\
\text { Category }\end{array}$ & description & count & $\begin{array}{l}\text { weight } \\
\text { (g) }\end{array}$ \\
\hline \multirow{25}{*}{ ST 11} & \multirow{3}{*}{1} & Cement & & 2 & 0 \\
\hline & & Metal & $\begin{array}{l}\text { Aluminum } \\
\text { wrapper }\end{array}$ & 1 & 0 \\
\hline & & Glass & Clear & 1 & 0 \\
\hline & \multirow{7}{*}{2} & Concrete & & 1 & 0 \\
\hline & & \multirow{2}{*}{ Glass } & Clear & 1 & 0 \\
\hline & & & Brown & 1 & 0 \\
\hline & & Limestone & & 3 & 7.5 \\
\hline & & Asphalt & & 1 & 74.5 \\
\hline & & Mortar & & 1 & 0 \\
\hline & & Slate & & 2 & 0 \\
\hline & \multirow{6}{*}{3} & Mortar & & 1 & 0 \\
\hline & & Slate & & 1 & 0 \\
\hline & & \multirow{2}{*}{ Metal } & Unidentified & 1 & 0 \\
\hline & & & Wire Nail & 2 & 0 \\
\hline & & \begin{tabular}{|l|} 
Charcoal and \\
macrobotanical
\end{tabular} & & 1 & 0 \\
\hline & & Glass & Purpled & 1 & 0 \\
\hline & \multirow{7}{*}{4} & Glass & Clear & 1 & 0 \\
\hline & & Bone & & 1 & 0.4 \\
\hline & & Brick/Tile & & 1 & 0 \\
\hline & & Metal & Unidentified & 2 & 0 \\
\hline & & Flagstone & & 2 & 0 \\
\hline & & Cement & & 1 & 0 \\
\hline & & Mortar & & 1 & 0 \\
\hline & \multirow{2}{*}{5} & Glass & Clear & 1 & 0 \\
\hline & & Bone & & 1 & 2.9 \\
\hline \multirow{14}{*}{ ST 12} & \multirow{3}{*}{1} & Ceramics & Stoneware & 1 & 0 \\
\hline & & Metal & Unidentified & 1 & 0 \\
\hline & & Other & Slag & 2 & 0 \\
\hline & \multirow{2}{*}{2} & \multirow{2}{*}{ Cement } & & 1 & 0 \\
\hline & & & & 1 & 0 \\
\hline & \multirow{4}{*}{3} & \begin{tabular}{|l|} 
Slate/ \\
Flagstone \\
\end{tabular} & & 1 & 0 \\
\hline & & Ceramics & \begin{tabular}{|l} 
Burnished, \\
foot \\
\end{tabular} & 1 & 0 \\
\hline & & Metal & Wire Nail & 1 & 0 \\
\hline & & Glass & Clear & 1 & 0 \\
\hline & \multirow{4}{*}{4} & \begin{tabular}{|l|} 
Charcoal and \\
macrobotanical
\end{tabular} & & 2 & 0 \\
\hline & & Brick & & 2 & 0 \\
\hline & & Slate & & 2 & 0 \\
\hline & & Tile & & 1 & 0 \\
\hline & 5 & Debitage & & 1 & 0 \\
\hline \multirow{3}{*}{ ST 13} & \multirow{3}{*}{1} & Other & Slag & 1 & 0 \\
\hline & & Bone & & 1 & 1.1 \\
\hline & & Ceramics & Native? & 1 & 0 \\
\hline
\end{tabular}

Table 4-2. Continued...

\begin{tabular}{|c|c|c|c|c|c|}
\hline Unit & level & $\begin{array}{l}\text { Artifact } \\
\text { Category }\end{array}$ & description & count & $\begin{array}{l}\text { weight } \\
\text { (g) }\end{array}$ \\
\hline \multirow{10}{*}{ ST 13} & 2 & Flagstone & & 1 & 0 \\
\hline & 3 & $\begin{array}{l}\text { Charcoal and } \\
\text { macrobotanical }\end{array}$ & & 1 & 0 \\
\hline & 3 & Metal & Handle & 1 & 0 \\
\hline & \multirow{7}{*}{4} & Unknown & & 1 & 1.3 \\
\hline & & \multirow{2}{*}{ Glass } & Brown & 1 & 0 \\
\hline & & & Clear & 1 & 0 \\
\hline & & Bone & & 1 & 0.1 \\
\hline & & Debitage & & 1 & 0 \\
\hline & & Mortar & & 10 & 0 \\
\hline & & Limestone & & 1 & 1 \\
\hline \multirow{2}{*}{ ST 14} & \multirow{2}{*}{1} & Tile & & 1 & 0 \\
\hline & & Concrete & & 1 & 0 \\
\hline
\end{tabular}

Shovel Tests 15, 16, 17, 23, 27, 29, 30, 31, 32, 34, 37, 40, 53, 63, and 73, seen on Figure 4-1, (Table 4-3) identified remnants of gravel pathways in the northeast portion of the site, as well as along the main central pathway through the property. The paths appear to be lined or surfaced with crushed limestone gravels, although in some instances pea gravels cemented with caliche may also have been used. Typically the path is either exposed at the surface or is buried within the first $10 \mathrm{~cm}$. The layer of crushed limestone does not seem to exceed $10 \mathrm{~cm}$ in thickness along the identified pathways in the eastern portion of the site.

Table 4-3. Results of Shovel Tests 15, 16, 23, and 27

\begin{tabular}{|c|c|c|c|c|c|}
\hline Unit & level & $\begin{array}{c}\text { Artifact } \\
\text { Category }\end{array}$ & description & count & $\begin{array}{l}\text { weight } \\
\text { (g) }\end{array}$ \\
\hline \multirow{6}{*}{ ST 15} & \multirow{3}{*}{1} & Glass & Chimney & 1 & 0 \\
\hline & & Other & Slag & 1 & 0 \\
\hline & & Cement & $\begin{array}{l}\text { Very Light } \\
\text { Weight }\end{array}$ & 2 & 0 \\
\hline & \multirow{3}{*}{2} & Concrete & & 3 & 0 \\
\hline & & Plastics & & 1 & 0 \\
\hline & & Brick & & 1 & 0 \\
\hline \multirow{8}{*}{ ST 16} & \multirow{2}{*}{2} & Asphalt & & 2 & 19.4 \\
\hline & & Debitage & & 2 & 0 \\
\hline & \multirow{3}{*}{3} & \begin{tabular}{|l|} 
Burned \\
rock
\end{tabular} & & 2 & 15.7 \\
\hline & & Metal & Wire Nail & 1 & 0 \\
\hline & & Asphalt & & 1 & 6.2 \\
\hline & \multirow{3}{*}{4} & Asphalt & & 1 & 107.3 \\
\hline & & Glass & Brown & 1 & 0 \\
\hline & & Brick & & 1 & 0 \\
\hline \multirow{2}{*}{ ST 23} & \multirow{2}{*}{2} & \multirow{2}{*}{ Glass } & Green & 1 & 0 \\
\hline & & & Brown & 1 & 0 \\
\hline
\end{tabular}


Table 4-3. Continued...

\begin{tabular}{|c|c|c|c|c|c|}
\hline Unit & level & $\begin{array}{c}\text { Artifact } \\
\text { Category }\end{array}$ & description & count & $\begin{array}{l}\text { weight } \\
\text { (g) }\end{array}$ \\
\hline \multirow{4}{*}{ ST 23} & \multirow{3}{*}{2} & Ceramics & Earthenware & 1 & 0 \\
\hline & & Burned rock & & 2 & 4.2 \\
\hline & & Debitage & & 1 & 0 \\
\hline & 3 & Other rock & & 2 & 0 \\
\hline \multirow{8}{*}{ ST 27} & \multirow{2}{*}{2} & Tile & & 2 & 0 \\
\hline & & Other rock & Basalt & 1 & 0 \\
\hline & \multirow{5}{*}{3} & Concrete & & 1 & 0 \\
\hline & & Debitage & & 1 & 0 \\
\hline & & Bone & & 1 & 0.4 \\
\hline & & Brick/Tile & & 1 & 0 \\
\hline & & Debitage & & 1 & 0 \\
\hline & 5 & Bone & & 1 & 2.3 \\
\hline
\end{tabular}

Shovel Tests 48 and 49 (Figure 4-1) reveal a brick walkway around the reflecting pool located in the western area of the park. The bricks appear to have been covered with pea gravels and may have been capped with some soil over which St. Augustine grass has grown. The brick pathway appears between 10 and $15 \mathrm{~cm}$ below surface.

A brick-paved pathway appears to lead from the reflecting pool to the center gravel pathway. Brick paving was uncovered in ST 95, 96, 97, 99, 100, and 104 (Figure 4-1; Table 4-4). A few fragments of debitage were recovered in the first level, possibly as a result of the fill brought in to cover the area. ST 106, near the center of the park and in line with the brick pavers, encountered concrete at approximately $20 \mathrm{cmbs}$. ST 97 indicated that at least a portion of the brick pathway located in the west-central area of the reflecting pool appears to have been removed and replaced with a French drain system. Several other STs around the site have gravels very similar to those found over the French drain. In addition, several cast iron grates cover what appears to be subsurface piping that is part of the French drain system across the park. The true extent and age of the drain system is not known at this time, although it appears to have disturbed the park's original architectural features in several places, suggesting that it post-dates the original construction of the park.

Shovel Tests 107-109 near the southwestern edge of the park (Figure 4-1), were excavated to gain more information about the bricks located in ST 67 (Table 4-5). ST 107 and 108 did not uncover a feature and revealed fill. Shovel Test 109 , located approximately 2 meters south of ST 67, was extended to uncover a feature consisting of a few paving stones laid in a row. This feature is located to the southwest of the reflecting pool. At this time, the nature of the feature is
Table 4-4. Artifacts Recovered from Shovel Tests 96, 97, 104, and 106

\begin{tabular}{|c|c|c|c|c|c|}
\hline Unit & level & $\begin{array}{c}\text { Artifact } \\
\text { Category }\end{array}$ & description & count & $\begin{array}{c}\text { weight } \\
\text { (g) }\end{array}$ \\
\hline \multirow{2}{*}{ ST 96} & \multirow{2}{*}{1} & Debitage & & 1 & 0 \\
\hline & & Cement & & 1 & 16.8 \\
\hline \multirow{7}{*}{ ST 97} & \multirow{5}{*}{1} & \multirow{3}{*}{ Metal } & \begin{tabular}{|l|} 
Insulated \\
Wire \\
\end{tabular} & 1 & 0 \\
\hline & & & Aluminum & 1 & 0 \\
\hline & & & Pull Tab & 2 & 0 \\
\hline & & Duct Tape & & 1 & 0 \\
\hline & & Debitage & & 3 & 0 \\
\hline & \multirow{2}{*}{3} & Brick/Tile & & 2 & 0 \\
\hline & & Other rock & Unidentified & 1 & 0 \\
\hline \multirow{5}{*}{ ST104 } & \multirow{5}{*}{3} & Asphalt & & 1 & 26.1 \\
\hline & & Concrete & & 1 & 0 \\
\hline & & Slate & & 4 & 0 \\
\hline & & Brick/Tile & & 9 & 0 \\
\hline & & Glass & Clear & 1 & 0 \\
\hline \multirow{2}{*}{ ST 106} & \multirow{2}{*}{3} & Asphalt & & 10 & 451.5 \\
\hline & & Cement & & 1 & 141.5 \\
\hline
\end{tabular}

Table 4-5. Artifacts Recovered from Shovel Tests 107 and 108

\begin{tabular}{|c|c|l|l|c|r|}
\hline Unit & level & \multicolumn{1}{|c|}{$\begin{array}{c}\text { Artifact } \\
\text { Category }\end{array}$} & description & count & $\begin{array}{c}\text { weight } \\
(\mathbf{g})\end{array}$ \\
\hline \multirow{2}{*}{ ST 107 } & \multirow{2}{*}{3} & $\begin{array}{l}\text { Lithic tools and } \\
\text { Cores }\end{array}$ & Core & 1 & 0 \\
\cline { 2 - 6 } & \multirow{2}{*}{5} & Brick/Tile & & 5 & 6.1 \\
\cline { 3 - 6 } & & Metal & Wire Nail & 1 & 0 \\
\hline \multirow{2}{*}{ ST 108 } & \multirow{2}{*}{5} & Cement & & 1 & 2.7 \\
\cline { 3 - 6 } & & Brick/Tile & & 1 & 0 \\
\hline
\end{tabular}

unclear although no cultural material, other than the bricks, was found in the area. The layer of soil covering the bricks and stones appears to be fill.

Shovel Tests 110-112 were excavated to help delineate the southern edge of the upper pool (Figure 4-1; Table 4-6). ST 111 revealed that the southern wall of the pool appears to have been sheared away. The eastern and western edges of the pool rim were located. However, the entire southern half of the pool's edge is missing. Based on historic photographs, the portion of the swimming pool wall that is missing is the portion that appears to have been supported by short concrete posts.

Shovel testing within the area of the footprint of the library produced quite a bit of glass, ceramic and construction material (Table 4-7). Shovel Tests 38 and 39 (Figure 4-1) appear to 
Table 4-6. Artifacts recovered from Shovel Tests $69,70,105$, and 110

\begin{tabular}{|c|c|c|c|c|c|}
\hline Unit & level & $\begin{array}{c}\text { Artifact } \\
\text { Category }\end{array}$ & description & count & $\begin{array}{l}\text { weight } \\
\text { (g) }\end{array}$ \\
\hline \multirow{4}{*}{$\begin{array}{l}\text { ST } 69 \\
\text { ST } 69 \\
\text { ST } 69 \\
\text { ST } 69\end{array}$} & \multirow{4}{*}{5} & Cement & & 3 & 0 \\
\hline & & Metal & Wire Nail & 1 & 0 \\
\hline & & $\begin{array}{l}\text { Mortar w/ } \\
\text { plaster }\end{array}$ & & 1 & 0 \\
\hline & & Wood & & 4 & 0 \\
\hline ST 70 & 3 & Brick & & 2 & 0 \\
\hline \multirow{10}{*}{ ST 105} & \multirow{3}{*}{3} & Brick & & 7 & 0 \\
\hline & & Glass & Brown & 1 & 0 \\
\hline & & Asphalt & & 1 & 111.1 \\
\hline & \multirow{4}{*}{4} & Asphalt & & 1 & 113.5 \\
\hline & & Glass & Clear & 1 & 0 \\
\hline & & Brick/Tile & & 5 & 0 \\
\hline & & Cement & & 1 & 0 \\
\hline & \multirow{3}{*}{5} & Asphalt & & 1 & 613.3 \\
\hline & & Glass & Brown & 2 & 0 \\
\hline & & Brick/Tile & & 3 & 0 \\
\hline ST 110 & 1 & Concrete & & 1 & 66.3 \\
\hline
\end{tabular}

Table 4-7. Artifacts Recovered from Shovel Tests 38,39 , and 113

\begin{tabular}{|c|c|c|c|c|c|}
\hline Unit & level & $\begin{array}{c}\text { Artifact } \\
\text { Category }\end{array}$ & description & count & $\begin{array}{l}\text { weight } \\
\text { (g) }\end{array}$ \\
\hline \multirow{14}{*}{ ST 38} & \multirow{3}{*}{3} & Wood & & 1 & 0 \\
\hline & & Plastics & & 1 & 0 \\
\hline & & Glass & Brown & 1 & 0 \\
\hline & \multirow{3}{*}{4} & Limestone & & 1 & 11.9 \\
\hline & & Debitage & & 1 & 0 \\
\hline & & Other rock & Road Gravel & 2 & 0 \\
\hline & \multirow{4}{*}{5} & Ceramics & Stoneware & 1 & 0 \\
\hline & & Glass & Clear & 1 & 0 \\
\hline & & Debitage & & 1 & 0 \\
\hline & & Charcoal and & & 4 & 0 \\
\hline & \multirow{4}{*}{6} & Bone & & 1 & 3.3 \\
\hline & & Metal & Scrap & 1 & 0 \\
\hline & & Limestone & & 1 & 13.2 \\
\hline & & Metal & Wire Nail & 2 & 0 \\
\hline \multirow{8}{*}{ ST 39} & \multirow{6}{*}{1} & Glass & Clear & 1 & 0 \\
\hline & & Metal & Unidentified & 1 & 0 \\
\hline & & Ceramics & & 1 & 0 \\
\hline & & Limestone & & 1 & 19.1 \\
\hline & & Plastics & & 1 & 0 \\
\hline & & Cement & & 3 & 0 \\
\hline & \multirow{2}{*}{2} & Limestone & & 1 & 9.5 \\
\hline & & Cement & & 2 & 0 \\
\hline
\end{tabular}

Table 4-7. Continued...

\begin{tabular}{|c|c|c|c|c|c|}
\hline Unit & level & $\begin{array}{c}\text { Artifact } \\
\text { Category }\end{array}$ & description & count & $\begin{array}{l}\text { weight } \\
\text { (g) }\end{array}$ \\
\hline \multirow{15}{*}{ ST 39} & 2 & Other & Slag & 6 & 0 \\
\hline & \multirow{3}{*}{3} & Debitage & & 1 & 0 \\
\hline & & Brick & & 2 & 0 \\
\hline & & Cement & & 1 & 0 \\
\hline & \multirow{5}{*}{4} & Brick/Tile & & 2 & 0 \\
\hline & & Other rock & Unidentified & 4 & 0 \\
\hline & & Debitage & & 4 & 0 \\
\hline & & Limestone & & 7 & 21.2 \\
\hline & & Cement & & 2 & 0 \\
\hline & \multirow{3}{*}{5} & Concrete & & 1 & 0 \\
\hline & & Debitage & & 1 & 0 \\
\hline & & Limestone & & 1 & 26.5 \\
\hline & \multirow{3}{*}{6} & Limestone & & 2 & 125.5 \\
\hline & & Asphalt & & 1 & 29 \\
\hline & & Metal & Wire Nail & 1 & 0 \\
\hline \multirow{28}{*}{ ST 113} & \multirow{5}{*}{2} & Glass & Green & 1 & 0 \\
\hline & & Brick/Tile & & 3 & 1.8 \\
\hline & & Cement & & 2 & 29.9 \\
\hline & & Glass & Clear & 4 & 0 \\
\hline & & Bone & & 1 & 1.1 \\
\hline & \multirow{12}{*}{2} & \begin{tabular}{|l|} 
Ceramics \\
\end{tabular} & Porcelain & 1 & 0 \\
\hline & & \multirow{4}{*}{ Glass } & Flat & 6 & 0 \\
\hline & & & Brown & 9 & 0 \\
\hline & & & Green & 5 & 0 \\
\hline & & & Chimney & 1 & 0 \\
\hline & & $\begin{array}{l}\text { Charcoal and } \\
\text { macrobotanical }\end{array}$ & & 1 & 0 \\
\hline & & Glass & Clear & 3 & 0 \\
\hline & & Ceramics & & 2 & 0 \\
\hline & & Bone & & 1 & 0.5 \\
\hline & & Brick/Tile & & 2 & 1.8 \\
\hline & & \multirow{2}{*}{ Metal } & Scrap & 1 & 0 \\
\hline & & & \begin{tabular}{|l|} 
Wire Nail \\
\end{tabular} & 4 & 0 \\
\hline & \multirow{11}{*}{4} & Bone & & 1 & 1.6 \\
\hline & & Brick/Tile & & 5 & 0 \\
\hline & & \multirow{7}{*}{ Glass } & \begin{tabular}{|l} 
Milk Glass \\
\end{tabular} & 1 & 0 \\
\hline & & & Brown & 3 & 0 \\
\hline & & & $\begin{array}{l}\text { Chimney } \\
\text { Glass }\end{array}$ & 2 & 0 \\
\hline & & & Green & 12 & 0 \\
\hline & & & Clear & 7 & 0 \\
\hline & & & Purpled & 4 & 0 \\
\hline & & & Flat & 7 & 0 \\
\hline & & Ceramics & $\begin{array}{l}\text { Porcelain } \\
\text { embossed }\end{array}$ & 2 & 0 \\
\hline & & $\begin{array}{l}\text { Charcoal and } \\
\text { macrobotanical }\end{array}$ & & 6 & 0 \\
\hline
\end{tabular}


Table 4-7. Continued...

\begin{tabular}{|c|c|c|c|c|c|}
\hline Unit & level & $\begin{array}{c}\text { Artifact } \\
\text { Category }\end{array}$ & description & count & $\begin{array}{l}\text { weight } \\
\text { (g) }\end{array}$ \\
\hline \multirow{11}{*}{ ST 113} & \multirow{7}{*}{4} & Ceramics & & 1 & 0 \\
\hline & & Other rock & Unidentified & 1 & 0 \\
\hline & & \multirow{4}{*}{ Metal } & Unidentified & 5 & 0 \\
\hline & & & Square Nail & 1 & 0 \\
\hline & & & Wire Nail & 6 & 0 \\
\hline & & & Thumb Tack & 1 & 0 \\
\hline & & Ceramics & & 1 & 0 \\
\hline & \multirow{4}{*}{5} & Metal & Unidentified & 1 & 0 \\
\hline & & Bone & & 1 & 2.4 \\
\hline & & Glass & Clear & 1 & 0 \\
\hline & & Ceramics & & 1 & 0 \\
\hline
\end{tabular}

be just outside the footprint of the structure, whereas Shovel Test 113 is within the footprint at the junction of the circular tower and the one-story rectangular structure.

A visit to the site a few days after the completion of Shovel Tests 1-113 to map the location of the features with the TDS revealed a new feature located in the southwest portion of the project area. The project area had been recently mowed and climbing temperatures had dried out some grasses. The dried grasses formed a rectangular outline connected to a slab of concrete the civil engineers had mapped in prior to the archaeological testing.

Following the mapping, additional shovel testing was conducted to determine what the feature was as well, as to investigate an anomaly seen on the 1939 aerial that had been pointed out during a recent visit to the site by Sarah Lake. Shovel Tests 114 and 115 (Figure 4-1) were excavated south of the Nike statue in order to determine if remnants of a possible feature still existed. Shovel Test 115 produced a piece of vertically inserted rebar beginning in Level 3 (20-30 cmbs). Both shovel tests encountered the water table in Level 4 (30-40 cmbs).

Shovel Test 116 (Figure 4-1) was excavated to $60 \mathrm{cmbs}$, and produced historic material in Levels 3 through 6 . The material increased in quantity in Levels 4 through 6 and included metal fragments, ceramics, clear glass, brown glass, green glass, a rifle hammer and a piece of fabric. With artifacts encountered in Level 6 (50-60 cmbs), it was decided to auger the shovel test. No historic material was recovered past $70 \mathrm{cmbs}$, but auguring was continued to approximately $123 \mathrm{cmbs}$ at which point the auger encountered an impenetrable surface.

Shovel Test 117 was excavated along the edge of the rectangular feature to determine its nature (Figure 4-1).
Within the excavation of the first $10 \mathrm{~cm}$, a lip on the edge of the cement feature was located. Soil was removed from under the cement lip revealing 2 inch blue tiles. Further excavation of the shovel test revealed that there were four rows of tiles, extending to approximately $20 \mathrm{~cm}$ below the rim of the lip at which time the wall of the feature changed to smooth cement. The shovel test was excavated to $60 \mathrm{cmbs}$ and produced no cultural material. The soil encountered consisted of a grayishwhite fill. Shovel Test 117 was augured to see if a surface was also present as in Shovel Test 116. The soil soon changed from the white fill to soil similar to that found in ST 116. Water began filling the hole at $90 \mathrm{cmbs}$. Historic material was recovered in the auger from approximately $80 \mathrm{cmbs}$ and extended to $140 \mathrm{cmbs}$. At $150 \mathrm{cmbs}$, the auger reached an impenetrable obstacle.

Shovel Test 118 was excavated to the east of ST 116 (Figure 4-1) to gain more information on the edge of the feature and to see if it contained similar historic material as in ST 116 and ST 117. ST 118 also revealed the same blue tiles as seen in ST 117. Historic artifacts were recovered in Levels 3 through $6(20-60 \mathrm{cmbs})$ and remained consistent with the types of material recovered from ST 116 and 117 (Table 4-8).

Table 4-8. Artifacts Recovered from Shovel Tests 116 through 118

\begin{tabular}{|c|c|c|c|c|c|}
\hline Unit & level & $\begin{array}{c}\text { Artifact } \\
\text { Category }\end{array}$ & description & count & $\begin{array}{c}\text { weight } \\
\text { (g) }\end{array}$ \\
\hline \multirow{22}{*}{ ST 116} & 0 & Glass & Clear & 1 & 0 \\
\hline & \multirow{4}{*}{3} & Metal & Scrap & 10 & 0 \\
\hline & & \begin{tabular}{|l} 
Copper \\
Bracelet Link
\end{tabular} & w/decoration & 1 & 0 \\
\hline & & Metal & Wire Nail & 3 & 0 \\
\hline & & Glass & Clear & 1 & 0 \\
\hline & \multirow{4}{*}{4} & Metal & Scrap & 13 & 0 \\
\hline & & Glass & Clear & 1 & 0 \\
\hline & & Metal Button & & 1 & 0 \\
\hline & & Metal & Unidentified & 3 & 0 \\
\hline & \multirow{4}{*}{5} & Asphalt & & 1 & 63.3 \\
\hline & & Glass & Clear & 1 & 0 \\
\hline & & Metal & Scrap & 3 & 0 \\
\hline & & Glass & Green & 1 & 0 \\
\hline & \multirow{9}{*}{6} & Bone & & 1 & 0.2 \\
\hline & & Glass & Brown & 1 & 0 \\
\hline & & Metal & $\begin{array}{l}\text { Rifle } \\
\text { Hammer }\end{array}$ & 1 & 0 \\
\hline & & Glass & Clear & 3 & 0 \\
\hline & & \multirow{2}{*}{ Metal } & Scrap & 19 & 0 \\
\hline & & & Wire Nail & 5 & 0 \\
\hline & & Ceramics & Earthenware & 1 & 0 \\
\hline & & Duct Tape & & 1 & 0 \\
\hline & & Glass & Aqua & 1 & 0 \\
\hline ST 117 & 0 & Glass & Aqua & 1 & 0 \\
\hline
\end{tabular}


Table 4-8. Continued...

\begin{tabular}{|c|c|c|c|c|c|}
\hline Unit & level & $\begin{array}{c}\text { Artifact } \\
\text { Category }\end{array}$ & description & count & $\begin{array}{l}\text { weight } \\
\text { (g) }\end{array}$ \\
\hline \multirow{5}{*}{ ST 117} & \multirow{5}{*}{0} & Burned rock & & 2 & 53.6 \\
\hline & & \multirow{2}{*}{ Glass } & Clear & 1 & 0 \\
\hline & & & Brown & 2 & 0 \\
\hline & & \multirow{2}{*}{ Metal } & Wire Nail & 1 & 0 \\
\hline & & & Scrap & 2 & 0 \\
\hline \multirow{15}{*}{ ST 118} & \multirow{3}{*}{3} & \multirow{2}{*}{ Glass } & Purpled & 1 & 0 \\
\hline & & & Clear & 3 & 0 \\
\hline & & Metal & Scrap & 1 & 0 \\
\hline & \multirow{3}{*}{4} & \multirow{3}{*}{ Glass } & Clear & 2 & 0 \\
\hline & & & Brown & 1 & 0 \\
\hline & & & \begin{tabular}{|l|} 
Clear w/ \\
metal cap
\end{tabular} & 1 & 0 \\
\hline & \multirow{6}{*}{5} & \multirow{3}{*}{ Glass } & Clear & 4 & 0 \\
\hline & & & Brown & 2 & 0 \\
\hline & & & Chimney & 1 & $\overline{0}$ \\
\hline & & Metal & Square Nail & 1 & 0 \\
\hline & & Rubber Tire? & & 2 & 0 \\
\hline & & Sewer Pipe & & 1 & 23.3 \\
\hline & \multirow{3}{*}{6} & \multirow{2}{*}{ Glass } & Brown & 2 & 0 \\
\hline & & & Clear & 4 & 0 \\
\hline & & \begin{tabular}{|l|} 
Metal \\
\end{tabular} & Bottle Cap & 1 & 0 \\
\hline
\end{tabular}

\section{Results of Test Unit Excavation}

Test Unit 1 was excavated to determine the depth of the brick pathway around the reflecting pool and across the decorative border (Figure 4-1). The unit was $1 \mathrm{~m}$ by $50 \mathrm{~cm}$ to span both the interior and the exterior of the concrete border. Within the unit, brick was encountered at $17 \mathrm{cmbs}$ inside the walkway, and $27 \mathrm{cmbs}$ outside the border. The border appears to be very similar to the concrete border that is found in the area of the Cuautemoc statue. The sediments within the unit differed inside and outside of the border. Inside, above the walkway, the area appears to have been filled with pea gravels and sand. Near the surface, a thin layer of soil was encountered that contained the roots of St. Augustine grass growing on the surface. Outside of the border, the first $8 \mathrm{~cm}$ consisted of a grayish black clay. Beneath the clay was grayish tan sand that extended to a depth of $21 \mathrm{cmbs}$. Sitting above the course of bricks on the exterior of the border was a thin layer of clay, approximately 4 to 6 $\mathrm{cm}$ in thickness. No cultural material was encountered during the excavation of the unit. Shortly after the bricks were uncovered on both sides of the border, water began to seep up and puddle in the unit.

Test Unit 2 was excavated to uncover a portion of the interior of the reflecting pool (Figure 4-1). The unit was $50 \mathrm{~cm} \times 50$ $\mathrm{cm}$ and started at the interior edge of the reflecting pool where one tile was exposed on the surface. The edge of the pool slopes towards the center. The pool had been filled in with gravel and then capped with soil. The southern wall profile of the unit revealed that between 11 and $21 \mathrm{cmbs}$ (to the base of the pool basin) gravels had been used to fill in the pool. The inner ring of the pool edge appears to have been painted with red paint (Figure 4-2). No additional tiles were noted along the pool basin. The unit produced no cultural material.

Test Unit 3 near the northeast corner of the park (Figure 4-1) was excavated near STs 7 and 13 that produced early twentieth century artifacts (Table 4-9). The purpose of the unit was to determine if the shovel tests had encountered the edge of a historic feature. Five $10-\mathrm{cm}$ levels were excavated in the unit; each level produced historic material, dating to the late Twentieth century. A fragment from the cement molding of the decorative tile panel of the Hildebrand gate located just to the north of the unit was recovered in Levels $2(10-20 \mathrm{cmbs})$ and 3 (20-30 cmbs). In Level $4(30-40)$ a fragment of ceramic sewer pipe was recovered as well as plastic and cement pieces. At approximately $47 \mathrm{cmbs}$, a grey pipe was uncovered that ran N/S, to the Hildebrand gate. At $51 \mathrm{~cm}$ below surface, a second grey PVC pipe was uncovered adjacent to the first and also running north to south. The pipes

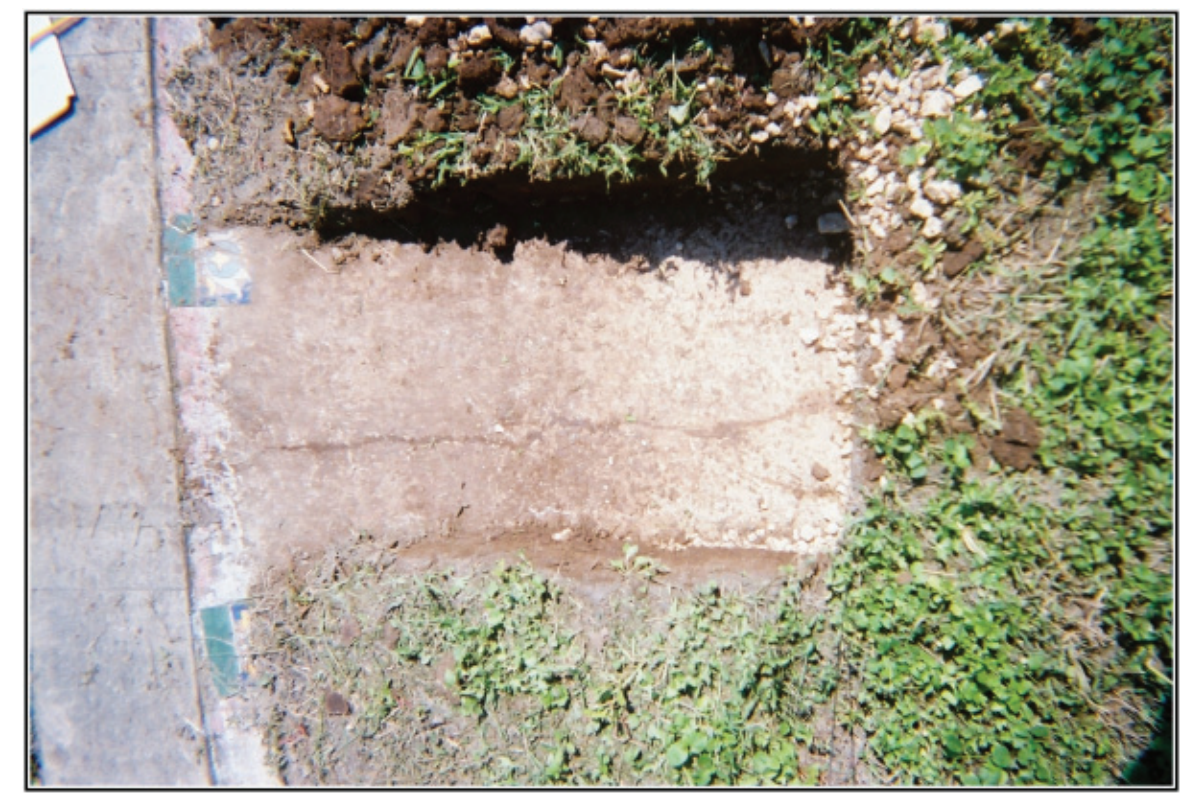

Figure 4-2. Photograph of Test Unit 2, located within the reflecting pool. 
Table 4-9. Artifacts Recovered from Test Unit 3

\begin{tabular}{|c|c|c|c|c|}
\hline Unit & level & $\begin{array}{c}\text { Artifact } \\
\text { Category }\end{array}$ & description & count \\
\hline \multirow{15}{*}{ TU 3} & \multirow{2}{*}{1} & \multirow{2}{*}{ Metal } & Roofing Tack & 1 \\
\hline & & & Wire & 1 \\
\hline & \multirow{5}{*}{2} & Brick & & 1 \\
\hline & & Cement & Moulding & 1 \\
\hline & & \multirow{2}{*}{ Glass } & Green & 2 \\
\hline & & & Clear & 4 \\
\hline & & Tar & & 1 \\
\hline & \multirow{3}{*}{3} & Cement & Moulding & 1 \\
\hline & & Glass & Clear & 1 \\
\hline & & Tile & Roof Tile & 1 \\
\hline & \multirow{3}{*}{4} & Cement & & 1 \\
\hline & & Ceramic & Sewer Pipe & 1 \\
\hline & & Plastic & Red & 1 \\
\hline & \multirow{2}{*}{5} & Ceramic & Sewer Pipe & 1 \\
\hline & & Tile & Roof Tile & 1 \\
\hline
\end{tabular}

appear to lead into the room located on the east portion of the Hildebrand entrance gate. Excavation of the unit was terminated at this point due to the presence of the pipes.

Test Unit 4 was located near the extreme northeast corner of the park in an area that produced prehistoric material to a depth of $60 \mathrm{cmbs}$ in nearby shovel tests (Figure 4-1). Excavating below $90 \mathrm{cmbs}$ in the small unit was difficult and therefore a hand-operated auger was used to reach to $115 \mathrm{cmbs}$. The cultural material encountered within the unit consisted of lithic debitage, cores, and burned rock (Table 4-10). No diagnostic material was recovered to provide a temporal association. The soils from the auger immediately below $90 \mathrm{~cm}$ changed in color and texture and produced no cultural material. No prehistoric materials were encountered at a depth exceeding $90 \mathrm{cmbs}$.

Table 4-10. Artifacts Recovered from Test Unit 4

\begin{tabular}{|c|c|c|c|c|c|}
\hline Unit & level & $\begin{array}{c}\text { Artifact } \\
\text { Category }\end{array}$ & description & count & $\begin{array}{l}\text { weight } \\
\text { (g) }\end{array}$ \\
\hline \multirow{10}{*}{ Unit 4} & \multirow{8}{*}{1} & Brick/Tile & & 1 & 0 \\
\hline & & Cement & & 2 & 0 \\
\hline & & $\begin{array}{l}\text { Charcoal and } \\
\text { macrobotanical }\end{array}$ & & 1 & 0 \\
\hline & & Concrete & & 1 & 0 \\
\hline & & Debitage & & 1 & 0 \\
\hline & & \multirow{2}{*}{ Glass } & Green & 1 & 0 \\
\hline & & & Olive Green & 1 & 0 \\
\hline & & Metal & Wire Nail & 2 & 0 \\
\hline & \multirow{2}{*}{2} & Brick/Tile & & 8 & 0 \\
\hline & & Burned rock & & 26 & 61.5 \\
\hline
\end{tabular}

Table 4-10. Continued...

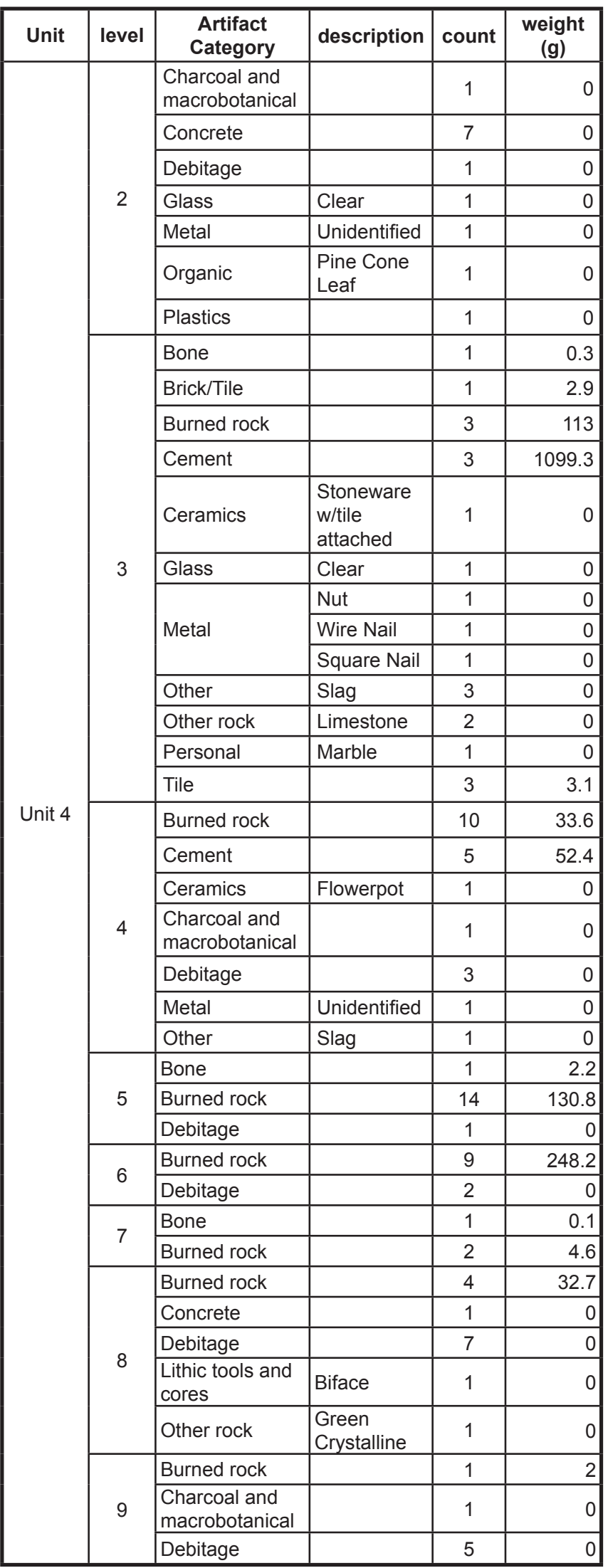


Test Unit 5 was positioned just west of TU 3 (Figure 4-1) in what was hoped to be undisturbed deposits. TU 5 produced prehistoric and historic materials to $50 \mathrm{cmbs}$ (Table 4-11). Levels 6 and 7 were sterile. Historic material encountered included wire, nails, glass fragments, asphalt, and metal toy horse, and granite fragments. The prehistoric material consisted of lithic debitage and a core. The prehistoric material was present in Levels 2 through $5(10-50 \mathrm{cmbs})$. Level 5 was the only level containing historic material. Levels 6 (50-60 $\mathrm{cmbs})$ and $7(60-70 \mathrm{cmbs})$ produced no cultural material. The water table was encountered near the bottom of Level 7 (60$70 \mathrm{~cm})$.

Table 4-11. Artifacts Recovered from Test Unit 5

\begin{tabular}{|c|c|c|c|c|c|}
\hline Unit & level & $\begin{array}{c}\text { Artifact } \\
\text { Category }\end{array}$ & description & count & $\begin{array}{c}\text { weight } \\
\text { (g) }\end{array}$ \\
\hline \multirow{28}{*}{ Unit 5} & \multirow{13}{*}{2} & Asphalt & & 1 & 23.6 \\
\hline & & Cement & & 6 & 90.1 \\
\hline & & Cement w/paint & & 1 & 0.3 \\
\hline & & Debitage & & 5 & 0 \\
\hline & & \multirow{2}{*}{ Glass } & Purpled & 1 & 0 \\
\hline & & & Clear & 1 & 0 \\
\hline & & Granite & & 1 & 390.5 \\
\hline & & \multirow{3}{*}{$\begin{array}{l}\text { Lithic tools and } \\
\text { cores }\end{array}$} & Core & 1 & 0 \\
\hline & & & $\begin{array}{l}\text { Edge } \\
\text { Modified }\end{array}$ & 1 & 0 \\
\hline & & & $\begin{array}{l}\text { Biface, } \\
\text { broken,2 } \\
\text { pieces }\end{array}$ & 2 & 0 \\
\hline & & \multirow{2}{*}{ Metal } & Fence Wire & 1 & 0 \\
\hline & & & Wire Nail & 2 & 0 \\
\hline & & Plastics & & 1 & 0 \\
\hline & \multirow{15}{*}{3} & Bone & & 1 & 1.3 \\
\hline & & Burned rock & & 1 & 6.9 \\
\hline & & Cement & & 8 & 351 \\
\hline & & $\begin{array}{l}\text { Charcoal and } \\
\text { macrobotanical }\end{array}$ & & 1 & 0 \\
\hline & & \multirow{2}{*}{ Glass } & Clear & 2 & 0 \\
\hline & & & Green & 1 & 0 \\
\hline & & Granite & & 6 & 695.2 \\
\hline & & \multirow{6}{*}{ Metal } & Pin & 1 & 0 \\
\hline & & & & 10 & 0 \\
\hline & & & Wire Nail & 6 & 0 \\
\hline & & & Wire & 5 & 0 \\
\hline & & & Handle & 1 & 0 \\
\hline & & & $\begin{array}{l}\text { Cartridge } \\
\text { Casing, } \\
\text { 38cal }\end{array}$ & 1 & 0 \\
\hline & & Other & Slag & 4 & 0 \\
\hline & & $\begin{array}{l}\text { Sewr Pipe w/ } \\
\text { lead glaze }\end{array}$ & & 1 & 11.2 \\
\hline
\end{tabular}

Table 4-11. Continued....

\begin{tabular}{|c|c|l|l|r|r|}
\hline Unit & level & \multicolumn{1}{|c|}{$\begin{array}{c}\text { Artifact } \\
\text { Category }\end{array}$} & description & count & $\begin{array}{c}\text { weight } \\
(\mathbf{g})\end{array}$ \\
\hline \multirow{4}{*}{ Unit 5 } & \multirow{3}{*}{4} & Bone & & 1 & 0.1 \\
\cline { 3 - 6 } & & $\begin{array}{l}\text { Charcoal and } \\
\text { macrobotanical }\end{array}$ & & 1 & 0 \\
\cline { 3 - 6 } & & Metal & Unidentified & 4 & 0 \\
\cline { 2 - 6 } & 5 & Debitage & & 1 & 0 \\
\hline
\end{tabular}

\section{Hand-Excavated Trench Results}

Shovel tests often did not allow us sufficient exposure to identify the nature of exposed features. Therefore, in several instances and locations within the park, we shifted to handexcavated trenches. Because by this point in the testing we had identified the extensive modern fill present across much of the park, it was felt that the less controlled trench excavations would not result in loss of information.

Trench 1 was excavated just north of the stage in an effort to locate the bottom of the lower pool assumed to have been situated just west of the upper pool (Figure 4-1). The trench was $145 \mathrm{~cm}$ in length, $31 \mathrm{~cm}$ wide and dug to a depth of 60 $\mathrm{cm}$ below surface. Water began to flow into the trench at 60 cmbs, so in the eastern portion an auger test was excavated to locate the bottom of the pool. At $140 \mathrm{cmbs}$, the auger bit contacted a solid impenetrable surface, most likely concrete, which represents the bottom of the pool. Approximately 80 $\mathrm{cm}$ to the west, another auger hole was excavated, but only reached a depth of $80 \mathrm{cmbs}$ before reaching the same obstacle. The sediments in this auger test appeared very different from that in the trench and may have been caliche fill.

Trench 2 was excavated along the northern wall of the swimming pool (Figure 4-1). The purpose was to search for the pool bottom. The grade of the pool wall is very steep and the area appears to have been filled in with hard packed caliche fill similar to that encountered in the previously mentioned auger hole. Excavation was stopped at $78 \mathrm{cmbs}$. Artifacts recovered in the fill included glass, tile, and asphalt.

Trench 3 was excavated over ST 33 in the west-central part of the park (Figure 4-1). ST 33 had exposed a cement curb. The trench was instrumental in uncovering a longer portion the curb and it also revealed that the curb is no longer intact but rather is sheared off at both ends. The trench was approximately $281 \mathrm{~cm}$ wide and $41 \mathrm{~cm}$ across at its maximum. The curb was encountered $10 \mathrm{~cm}$ below the surface (Figure 4-3). The curb could either be part of the lining of the gravel path leading in the direction of Quinta Maria, or may have been used as a platform for a piece of art work. Artifacts encountered while 


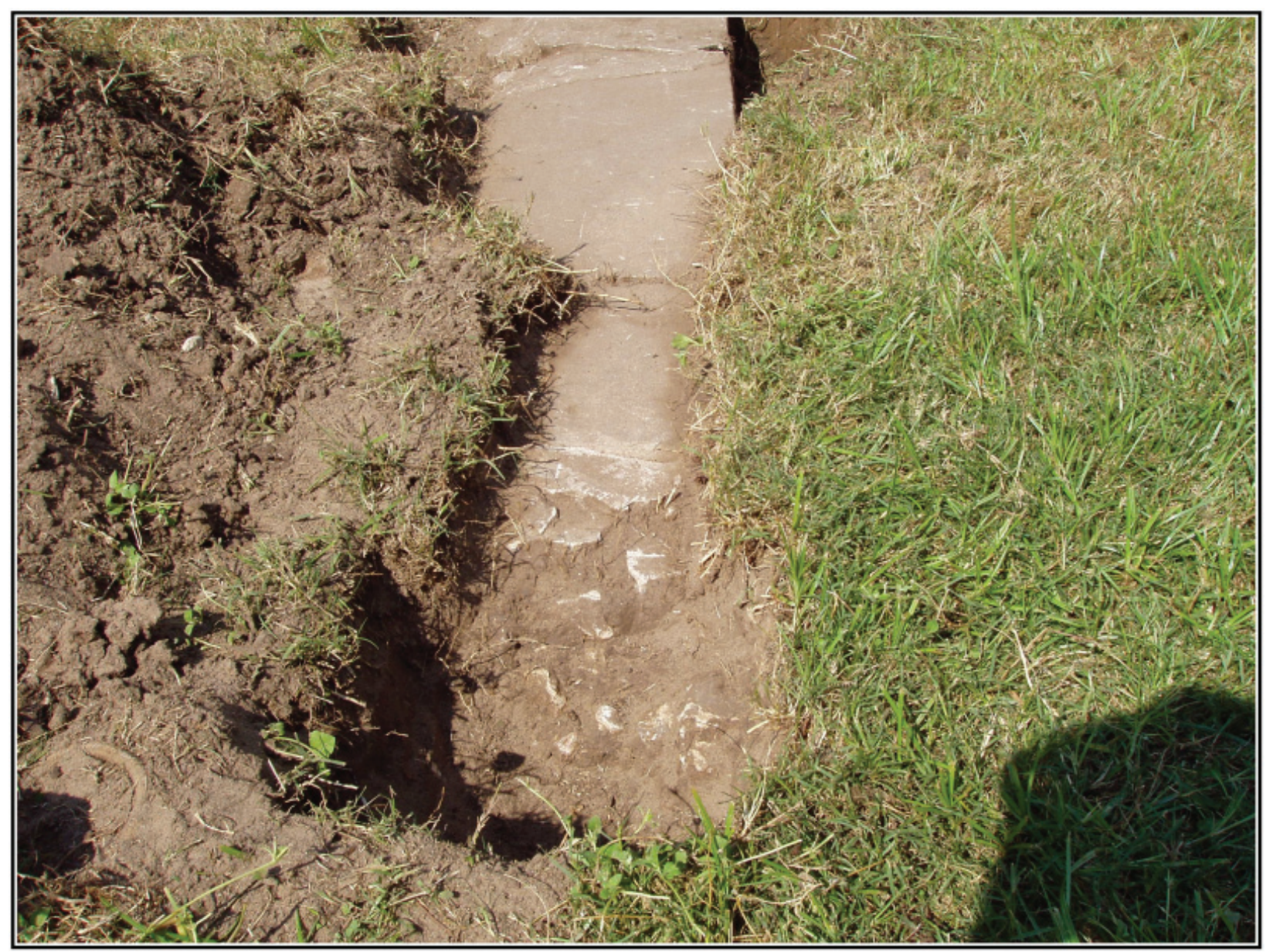

Figure 4-3. Photograph of the cement feature uncovered in ST 33 and Trench 3.

excavating the trench included burned rock, glass, metal, plastic, debitage and cement (Table 4-12).

Trench 4 was excavated to bisect the western outline of the windmill/library near the center of the park (Figure 4-1). A layer of brick pavers was uncovered approximately $5 \mathrm{cmbs}$ and the eastern portion of the trench produced much rubble from the structure. The brick walkway sits atop a hard packed caliche base. On either side of the walkway, fragments of the library building wall were located. The wall was constructed of concrete with wire mesh support, and painted to resemble cut stone. Artifacts included nails, tile, and cement fragments (Table 4-13).

\section{Coring Results}

One sediment/pollen core was extracted from the area that will be impacted by the construction of the pedestrian bridge linking Miraflores to Brackenridge Park. The coring was
Table 4-12. Artifacts Recovered from Trench 3

\begin{tabular}{|c|l|l|c|r|}
\hline Unit & \multicolumn{1}{|c|}{$\begin{array}{c}\text { Artifact } \\
\text { Category }\end{array}$} & description & count & $\begin{array}{c}\text { weight } \\
(\mathbf{g})\end{array}$ \\
\hline \multirow{5}{*}{ Trench 3 } & Debitage & & 1 & 0 \\
\cline { 2 - 5 } & Cement & & 2 & 7 \\
\cline { 2 - 5 } & $\begin{array}{l}\text { Charcoal and } \\
\text { macrobotanical }\end{array}$ & & 3 & 0 \\
\cline { 2 - 5 } & Burned rock & & 4 & 5 \\
\cline { 2 - 5 } & Glass & Green & 3 & 0 \\
\cline { 2 - 5 } & Metal & Pull Tab & 1 & 0 \\
\cline { 2 - 5 } & Plastics & & 1 & 0 \\
\hline
\end{tabular}

conducted by hand due to the high water table at the time which prevented the use of mechanical coring equipment. Two PVC pipes measuring 2-inches in diameter were driven into the ground by hammering a metal pipe outer sleeve into the ground. The core extended to a depth of 1.8 meters below the surface. Once the metal pipe was pulled from the ground and after the PVC inert pipes containing the matrix 
Table 4-13. Artifacts Recovered from Trench 4

\begin{tabular}{|c|c|c|c|c|c|}
\hline Unit & level & $\begin{array}{c}\text { Artifact } \\
\text { Category }\end{array}$ & description & count & $\begin{array}{c}\text { weight } \\
\text { (g) }\end{array}$ \\
\hline \multirow{31}{*}{$\begin{array}{c}\text { Trench } \\
\quad 4\end{array}$} & \multirow{8}{*}{1} & \begin{tabular}{|l|} 
Charcoal and \\
macrobotanical
\end{tabular} & & 2 & 0 \\
\hline & & Ceramics & Earthenware & 1 & 0 \\
\hline & & Asphalt & & 1 & 9.6 \\
\hline & & Tile & & 29 & 39.4 \\
\hline & & Metal & Wire Nail & 10 & 0 \\
\hline & & Cement & & 22 & 421.7 \\
\hline & & Tile w/cement & & 2 & 11.7 \\
\hline & & Other rock & Ochre & 1 & 0 \\
\hline & \multirow{15}{*}{2} & Tile & & 30 & 53.4 \\
\hline & & Burned rock & & 2 & 6.2 \\
\hline & & Other rock & Limestone & 3 & 0 \\
\hline & & Cement w/paint & & 6 & 198.3 \\
\hline & & Metal & Wire Nail & 6 & 0 \\
\hline & & Cement & & 4 & 3.6 \\
\hline & & Bone & & 1 & 2.5 \\
\hline & & Concrete & & 1 & 90.4 \\
\hline & & Cement w/paint & & 15 & 204.3 \\
\hline & & \begin{tabular}{|l|} 
Metal \\
\end{tabular} & Wire Nail & 9 & 0 \\
\hline & & Other rock & Crystal & 2 & 0 \\
\hline & & Cement w/tile & & 4 & 182.6 \\
\hline & & Brick/Tile & & 12 & 17.6 \\
\hline & & Cement & & 4 & 0 \\
\hline & & Other & Slag & 1 & 0 \\
\hline & \multirow{8}{*}{3} & Tile & & 26 & 50.5 \\
\hline & & Metal & Wire Nail & 9 & 0 \\
\hline & & $\begin{array}{l}\text { Cement w/ } \\
\text { reinforcemnt }\end{array}$ & & 7 & 181.3 \\
\hline & & Glass & Clear & 2 & 0 \\
\hline & & Cement & & 9 & 57.9 \\
\hline & & Ceramics & Earthenware & 1 & 0 \\
\hline & & Cement w/Tile & & 2 & 39.9 \\
\hline & & Cement w/paint & & 10 & 310.1 \\
\hline
\end{tabular}

were extracted from the metal sleeves, they were returned to the CAR laboratory. Next, the PVC pipes containing the sediment segments were split length-wise to expose the contents and allow for observation of the sediment layers. No cultural material was noted in the cores. A two-inch long sediment sub-sample was pulled from the base of the core and submitted to Dr. Vaughn M. Bryant at the Palynology Laboratory of the Department of Anthropology of Texas A\&M University to determine the degree of pollen preservation at the site. The results of the pollen analysis indicated that pollen preservation was very poor and the pollen assemblage extracted from the sample represents a highly degraded sample that is not representative of the full pollen spectra originally present in the soil matrix. Based on this result, CAR determined that no additional cores were to be extracted and additional pollen analyses were not warranted.

\section{Geo-technical Coring Results}

On March 17, 2008, Steve Tomka monitored the geotechnical coring within the vicinity of the sediment/pollen cores previously removed by CAR. The core was located to the west of the reflecting pool, in the area to be affected by the construction of the pedestrian bridge linking Brackenridge Park and Miraflores. The core was excavated to determine the sediment characteristics within the pedestrian bridge footprint. Inspection of the upper layers (approximately 2.0 meters) of the core sediments indicated that there was no cultural material present in the matrix. This finding is consistent with the lack of cultural materials in the sediment/ pollen core extracted by CAR from a nearby location. 



\section{Chapter 5: Discussion and Recommendations}

\begin{abstract}
Discussion
Although the waterlogged nature of the deposits prevented full implementation of the work proposed in the SOW, a large portion of the site was investigated. Throughout the course of the fieldwork, the northeast portion of the park remained too wet to allow for shovel testing. Natural springs had developed in the area due to the increased amount of rain San Antonio witnessed during the 2007 summer.
\end{abstract}

Historic research conducted by the Miraflores Team during the fieldwork unearthed additional information and photographs that aided in the interpretation of features uncovered at the site, and also helped to better define the layout of the park. Photographs taken over the years helped reveal the transformation that has occurred at the park through the decades. The photographs, combined with the results of subsurface testing, have brought to light several issues that will have to be addressed during the planning and construction/implementation phases of the project.

\section{The Amount of Fill/Silt Present Within the Project Area}

Many of the primary features within the project area have been partially covered by fill introduced either through artificial means or by over-bank flooding of the river. The less extreme cases tend to have a few centimeters of soil that cover the bases of the feature, such as the Cortez Bench located in the northwest portion of the site, the Urrutia Bench, located in the northeast portion of the site, and portions of the gravel pathway. In these cases, it appears that the soil was deposited naturally, rather than introduced by humans.

In other areas such as the reflecting pool, the stage, and the pool south of the artesian well, large amounts of fill appear to have been brought in to level and perhaps raise the grade, and bury abandoned features. The reflecting pool was capped with a layer of gravel, and then sandy soil (Figure 5-1). Also, the brick pathway from the reflecting pool to the main gravel path is buried under $15-20 \mathrm{~cm}$ of fill (Figure 5-2). It is likely

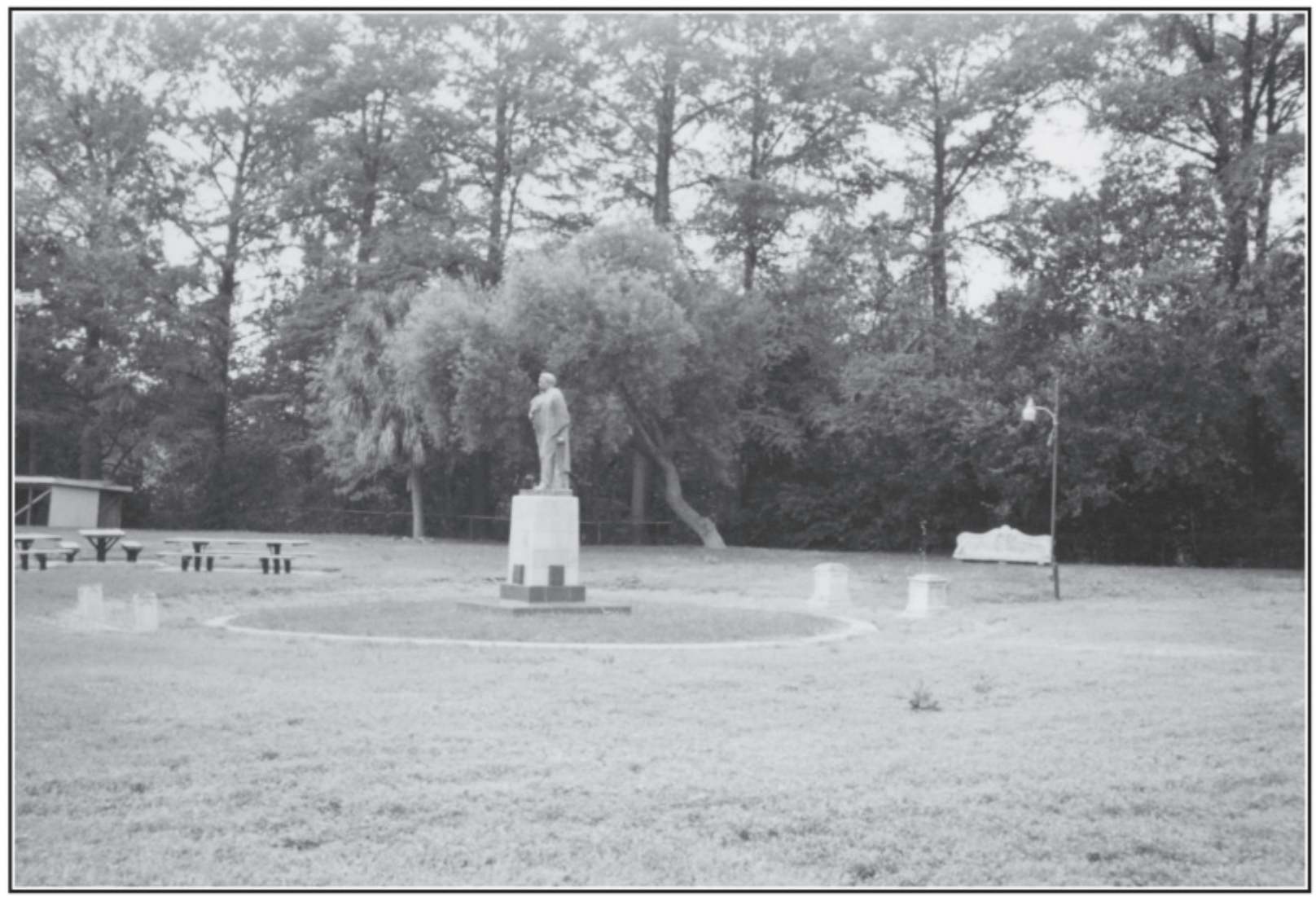

Figure 5-1. Photograph of the filled in reflecting pool. 


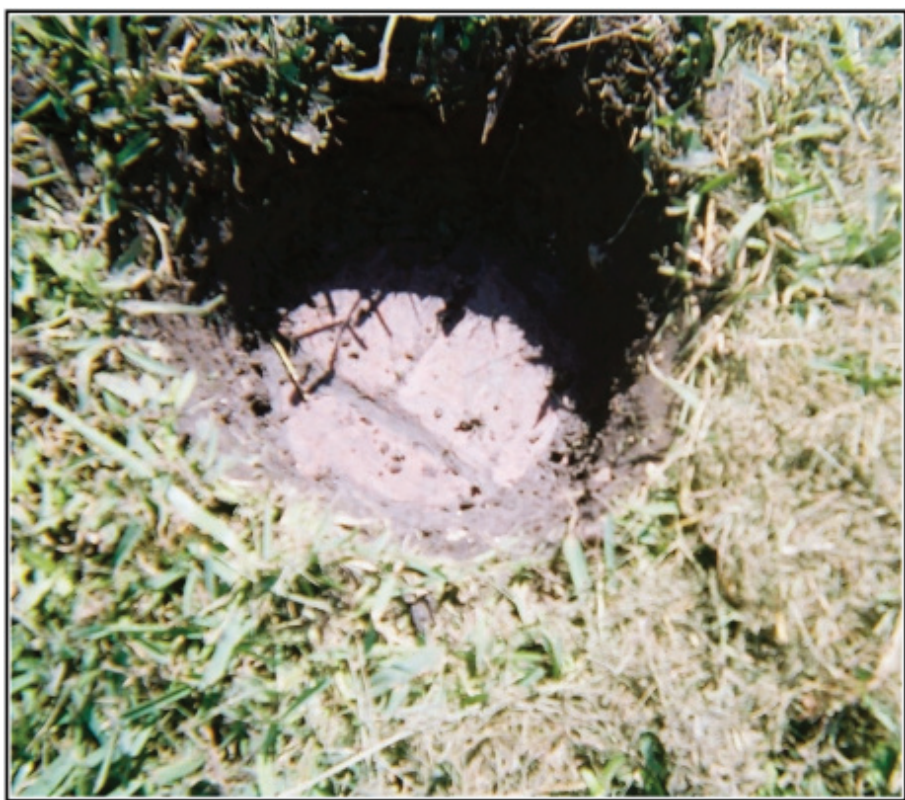

Figure 5-2. Photograph of Shovel Test 99 revealing portion of brick pathway below surface. that the brick walkway was purposefully covered, because the entire area contains fill and the picnic tables (which were installed in the 1960s) appear to have been placed over the path. Just to the northwest of the reflecting pool is the Banco del Amor (Figure 5-3). Comparisons of modern and historic photographs of the bench reveal that today there is approximately one to one and a half feet $(45 \mathrm{~cm})$ of sediments covering the base of the feature.

Historic photographs of the stage reveal that there is up to four feet $(120 \mathrm{~cm})$ of fill in some areas surrounding the feature (Figure 5-4). Shovel Test 103, located at the eastern edge of the stage, revealed that another step is present below the modern surface. Early photographs reveal additional tile work along the western portion of the stage that is now buried. The photographs also indicate that a water feature ran beneath the middle of the stage. The entryway for this channel is barely visible today.

To the northeast of the stage is an upper pool possibly fed by the artesian well. A portion of the pool's edge is visible

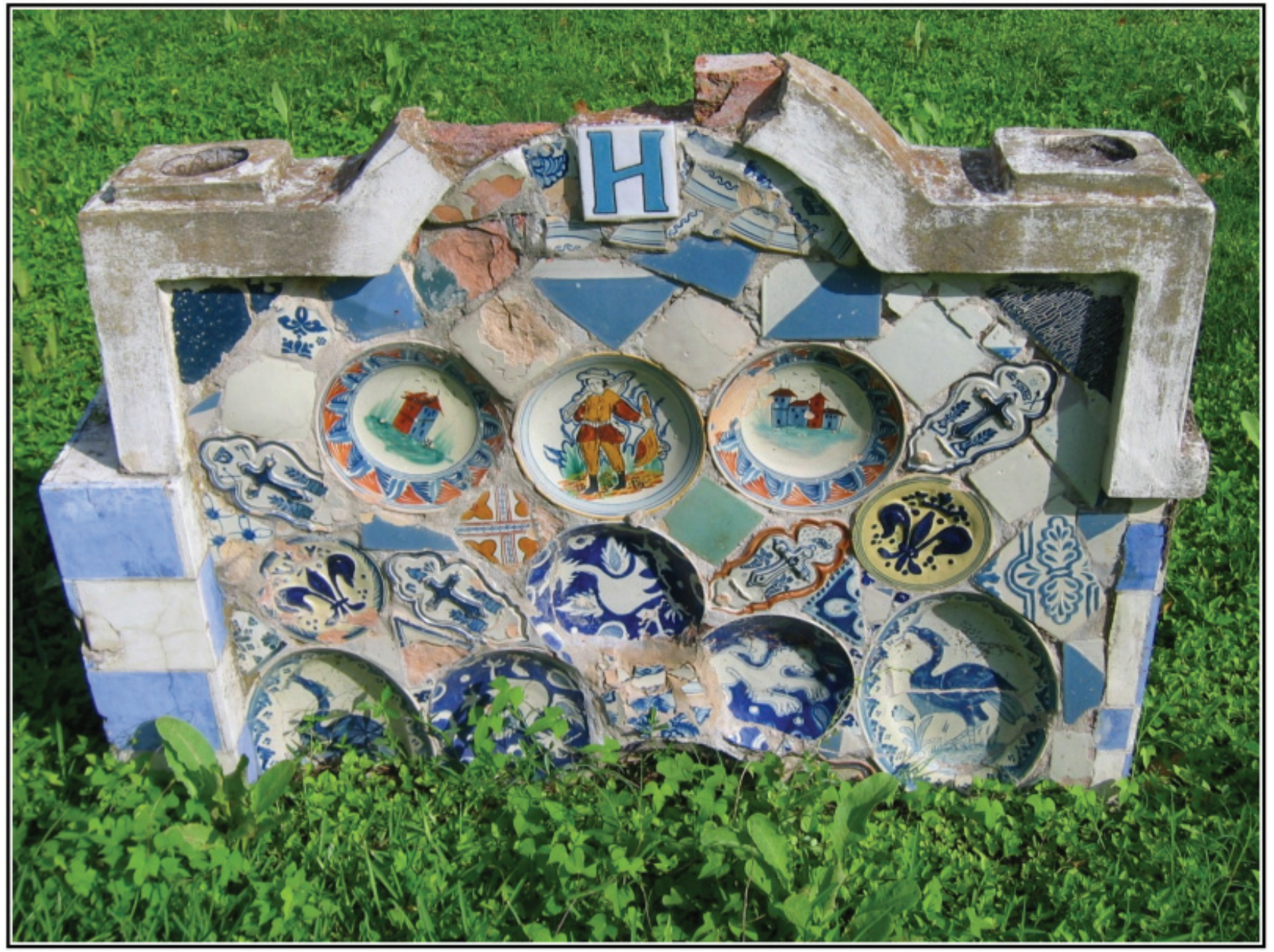

Figure 5-3. Recent photograph of the Banco del Amor. Fill completely covers the bench seat. 


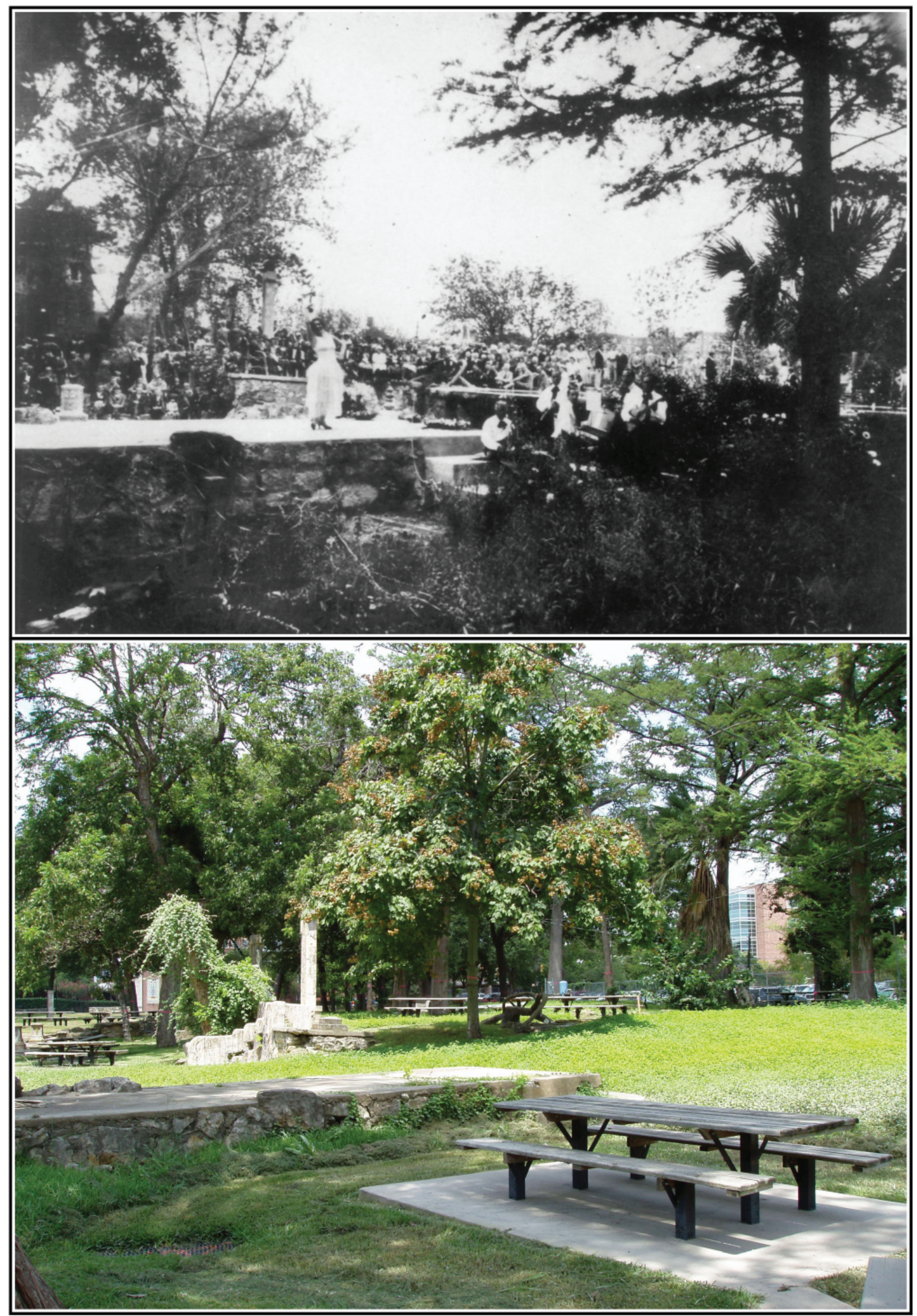

Figure 5-4. Historic and recent photograph of the stage indicating the amount of fill present today. 
today, but shovel tests reveal that about half of the feature has been sheared away. Shovel Tests 105 and 111 reveal that the pool rim does not extend further than these points. Hard packed caliche was used to fill in the remaining portion of the pool to create a slope to the picnic tables near the pavilion. The caliche fill also creates a slope in the area that was the lower pool that housed water plants at the base of the upper pool. Auguring in Trench 1 indicates that the base of the lower pool is approximately five feet below the current surface. Historic

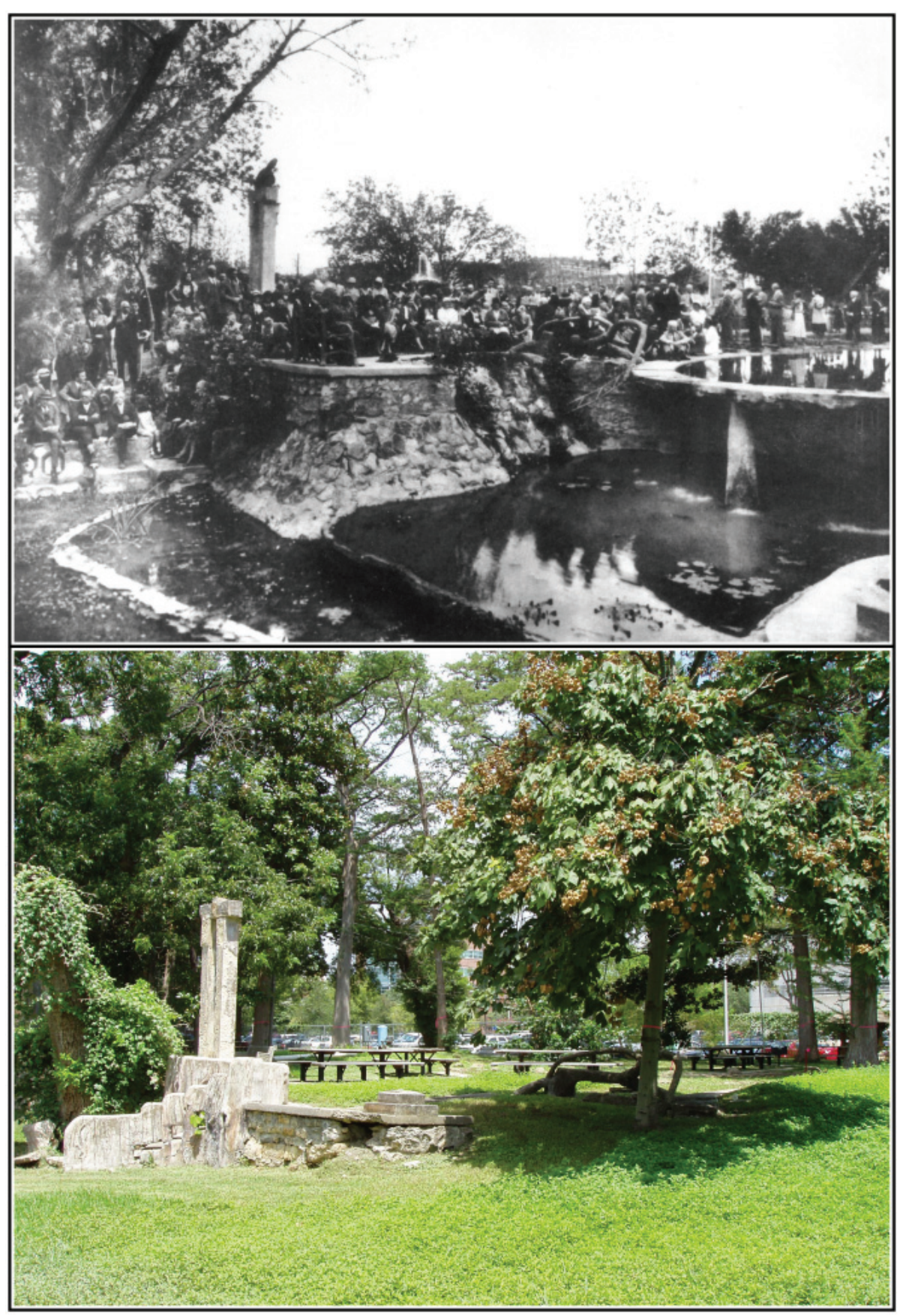

Figure 5-5. Historic and recent photograph of the lower and upper pool. Recent photograph confirms the amount of fill in the area. photographs confirm that a great amount of fill was used to level this area of the park (Figures 5-5 and 5-6).

The brick pathway leading from the reflecting pool to the main gravel path poses an interesting question. The brick appears approximately $15 \mathrm{~cm}$ below the current surface. Portions of the gravel pathway are eroding on the surface. Has the gravel path been built up over the years to deal with the high water table at the site? Photographs from 1995 show that the gravel path was well kept, but show no evidence of a brick path (Figure 5-7).

An additional step is buried beneath $10 \mathrm{~cm}$ of soil at the base of the Rodriguez stairway located just north of the stage. Shovel Test 61 revealed that the step resembles the remainder of the piece, with faux wood grain in concrete. Currently, railroad ties line the pathway to the staircase, though the grass has overgrown the area.

The focal point of the eastern portion of the park was the fountain that tied into the artesian well. The fountain was constructed of concrete, and allowed the water to cascade down the various rock-like concrete layers (Figures 5-8 and 5-9). By 2002 , the fountain was removed by groundskeepers of The University of the Incarnate Word. Shovel Test 44 revealed that the basin of the fountain is still present, approximately $45 \mathrm{~cm}$ below the current surface.

\section{The Water Table}

San Antonio experienced an extremely wet summer with a total of 45.46 inches of rainfall between January 1 and October 22, 2007. Due to the amount of rain, the discharge of the San Antonio River was higher than in previous years. Natural springs have popped up within the project area, mostly confined to the northwestern portion of the site. The increased amount of water affected the testing of the project area. The entire northwest portion of the site was not shovel 


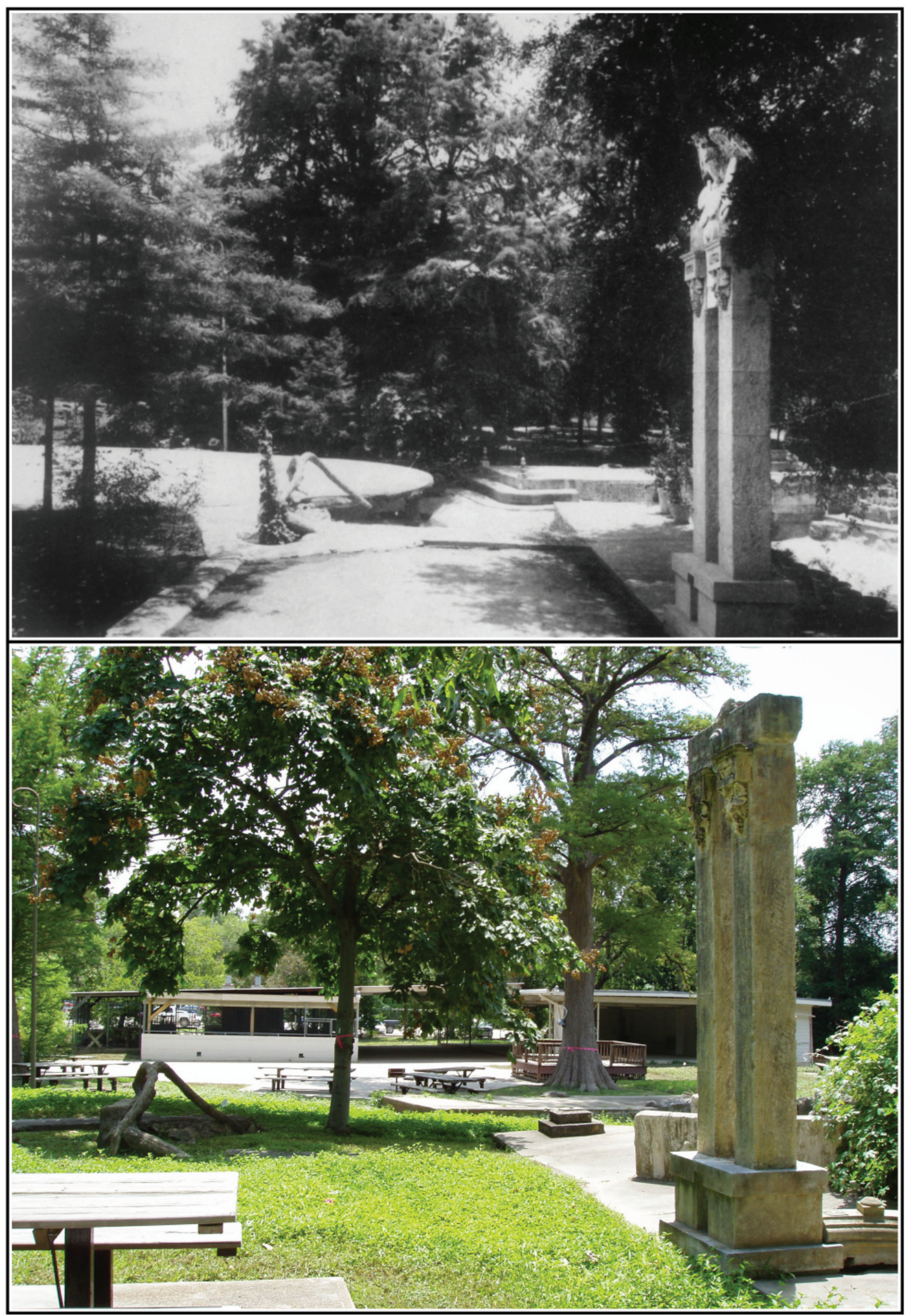

Figure 5-6. Comparison of historic and recent photographs of the path leading alongside the upper pool. 


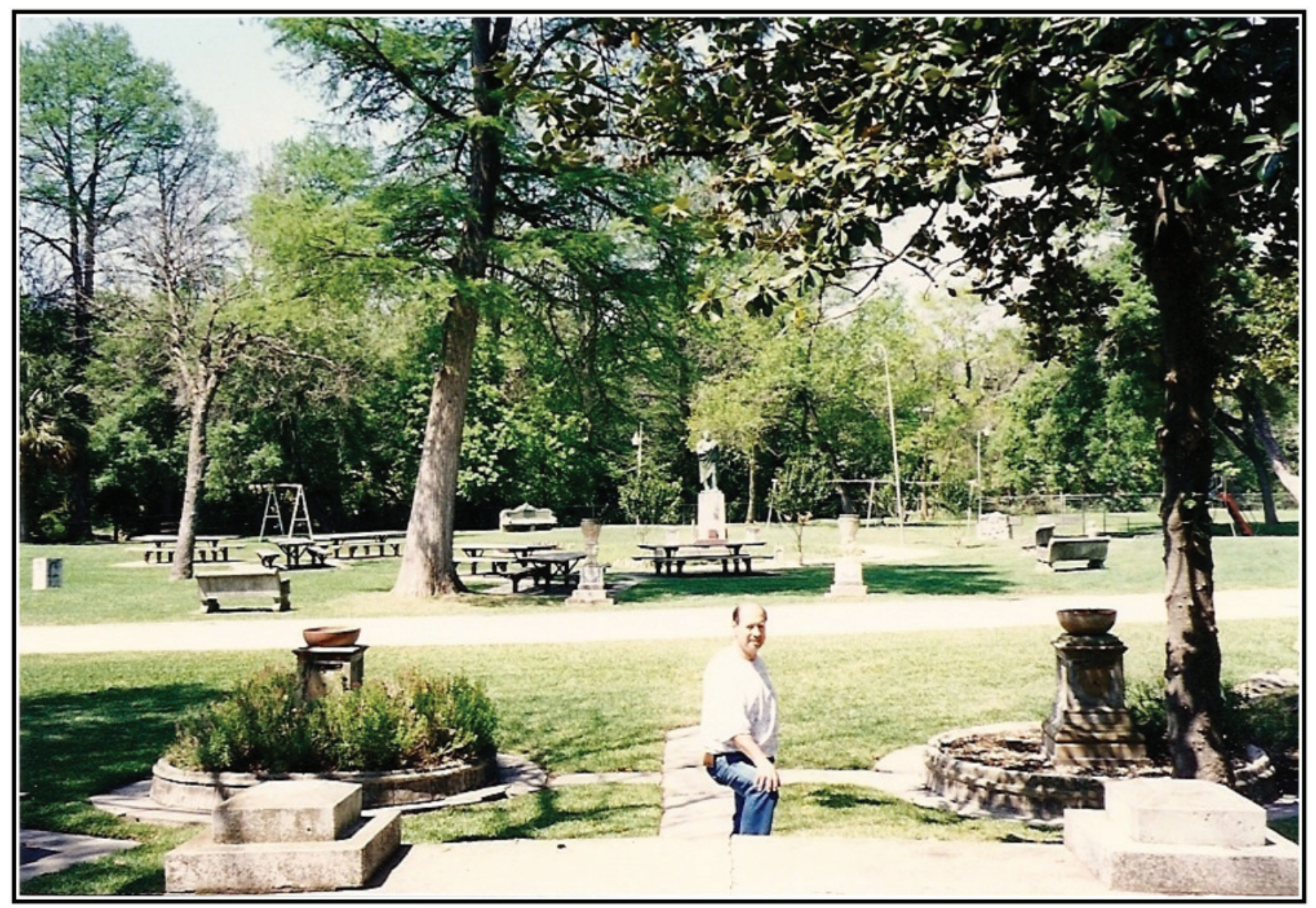

Figure 5-7. Photograph taken by family members in 1995 showing the gravel path and reflecting pool in background.

tested due to the swampy conditions (Figure 5-10). With the exception of the northeast portion situated above the 100 year flood plain, the remainder of the project area typically saw water seeping into the shovel tests and trenches between 40 and $60 \mathrm{~cm}$ below the current surface. The water table appears to have been lower during construction of the features within the park between the 1920s and the 1940s. Currently, several of the features, including the reflecting pool path, would be waterlogged if the upper layers of soil are removed to expose them (Figure 5-11).

Sometime after the property no longer belonged to Dr. Urrutia, a French drainage system was installed possibly to solve the drainage issues at the site. Evidence of the French drain is seen in Shovel Tests 97 and 98, and possibly in Shovel Tests 41 and 42. Other localities within the project area exhibited the similar gravels as seen covering the PVC pipe in ST 98. The French drains may tie into the grated drains located around the park grounds. Water was noted collecting in the grated drains, though the extent and layout of the system are unknown.
If the features at the park are to be excavated to the level they were originally, the current water table level will likely pose a problem and may make portions of the park inaccessible on a seasonal or intermittent basis.

\section{Additional Considerations}

No evidence of the gravel pathway was noted in shovel tests located near the Hildebrand entrance or at the southern most portion of the project area. Historic aerials reveal that the paths did exist in these areas at one time. The northern portion of the site produced historic material consisting of glass fragments, concrete, butchered bone, and ceramic fragments immediately below the surface. Test Units 3 and 5 also produced historic material. The absence of the gravel path suggests that this area near the gate was graded sometime following the sale of the property by Dr. Urrutia.

An unidentified feature was located to the southwest of the reflecting pool in Shovel Test 109. Initially, bricks were uncovered in Shovel Test 67 which may lead to the 

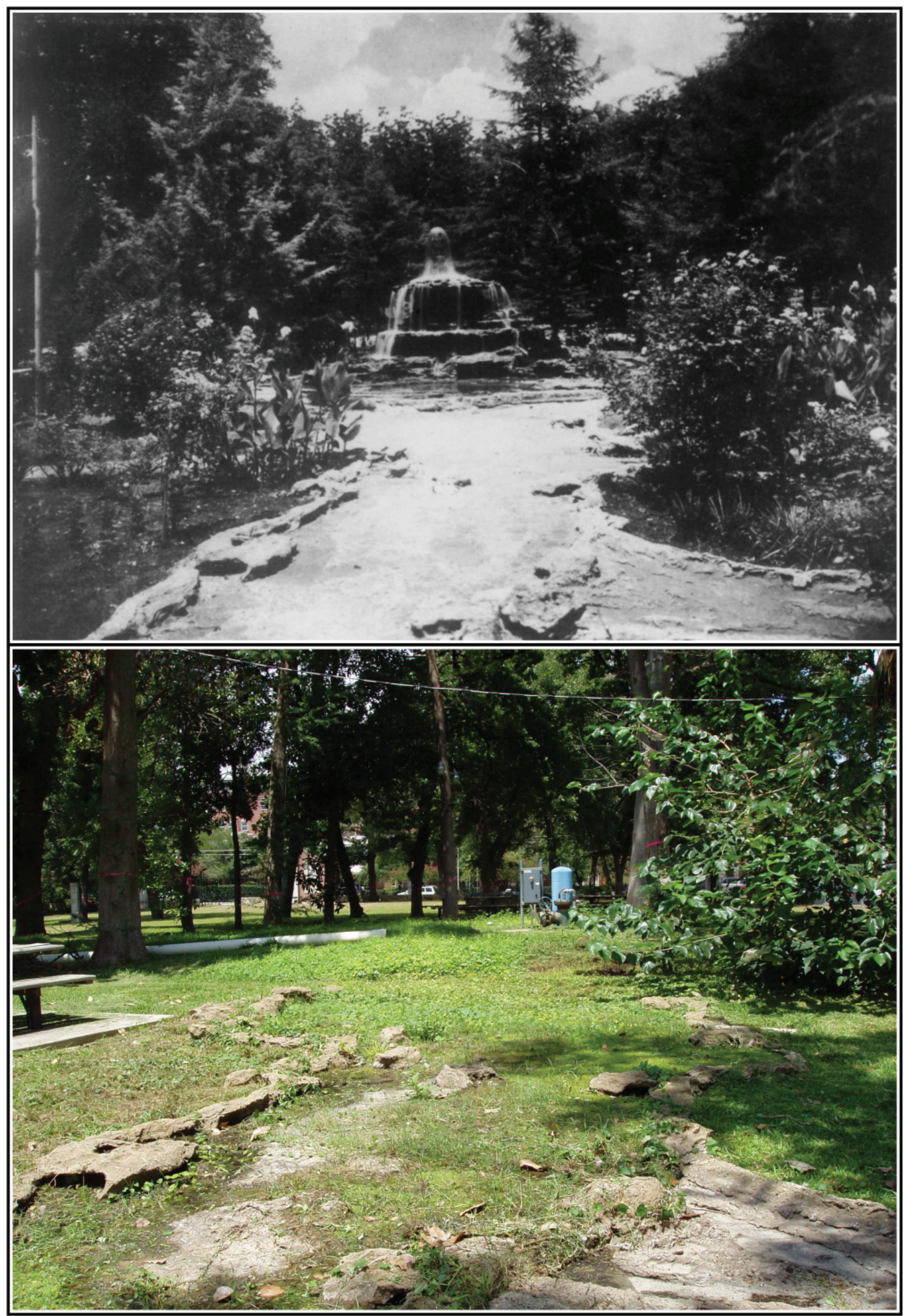

Figure 5-8. Comparison of historic and recent photographs of the artesian well fountain. Recent photograph shows the overgrowth on the water paths. 


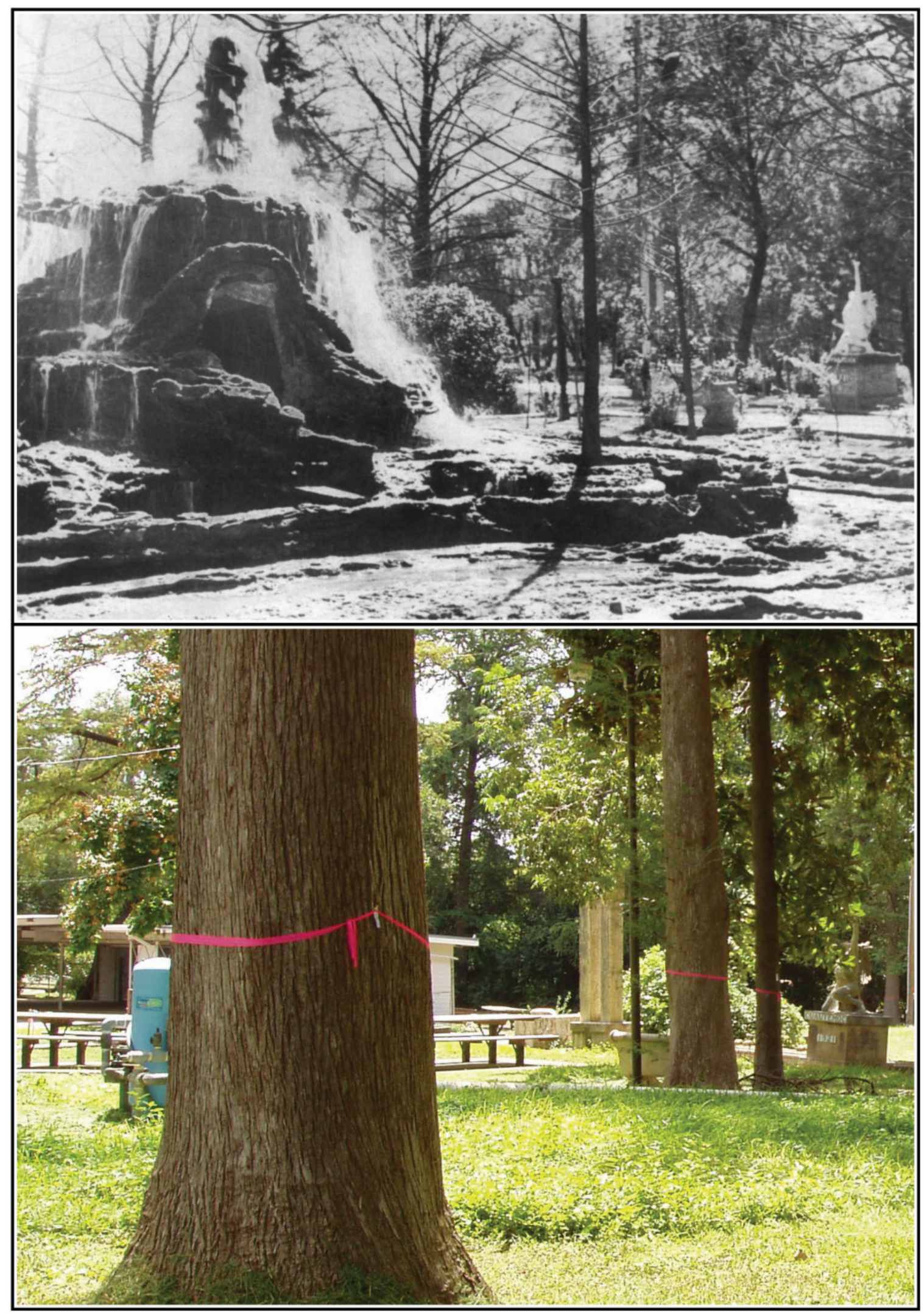

Figure 5-9. Comparison of historic and recent photographs of the fountain. Recent photograph shows the remarkable growth of a number of large trees as well as the removal of the fountain. 


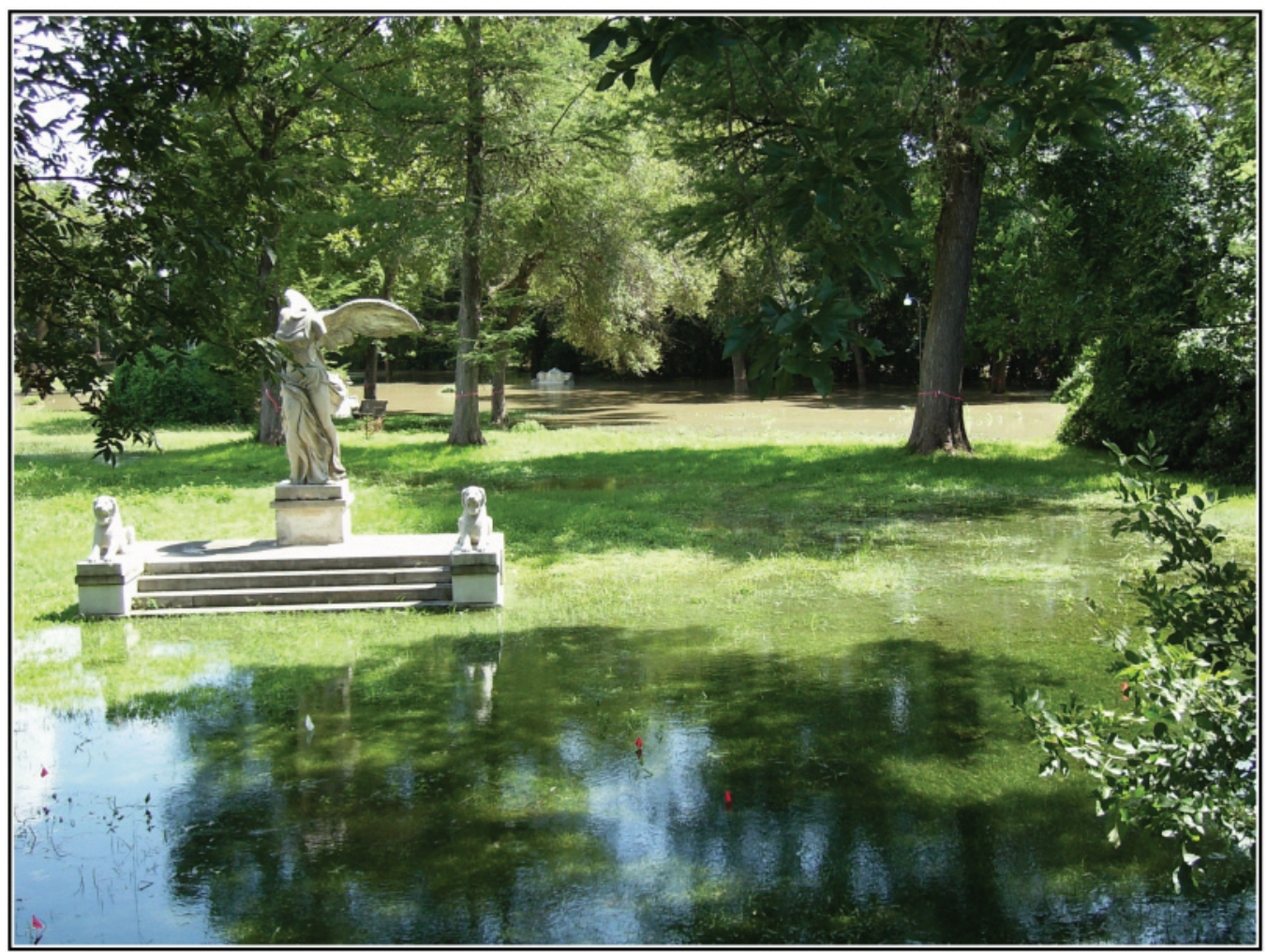

Figure 5-10. Photograph of standing water found in the northwest portion of the project area prior to the testing.

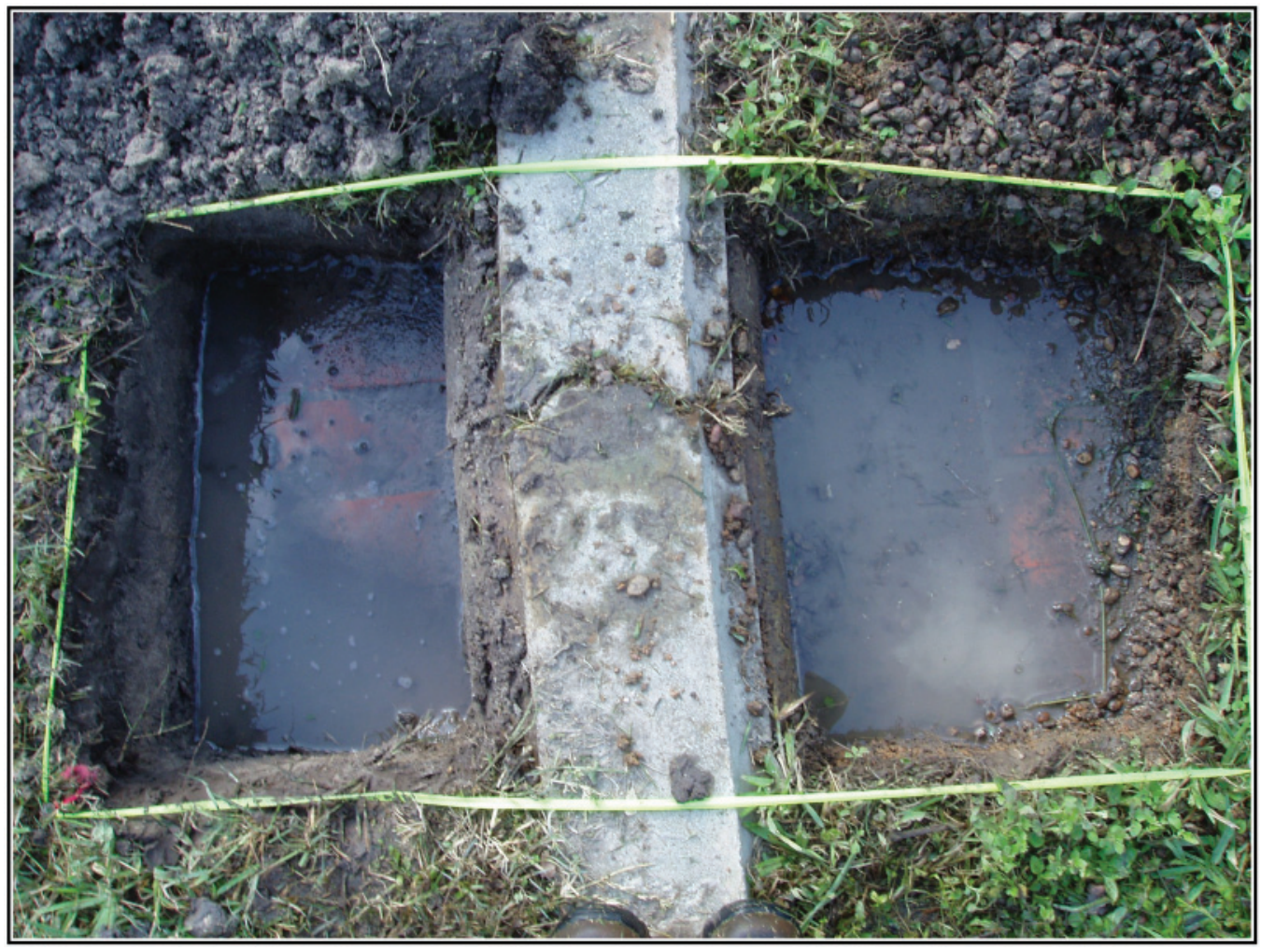

Figure 5-11. Photograph of water seeping into Unit 1 located along the reflecting pool path. 
reflecting pool pathway. ST 109 encountered large limestone pavers (Figure 5-12). The shovel test was widened into a hand-excavated trench to investigate the feature and revealed several adjoining limestone pavers.

A large amount of rubble from the library structure is located beneath the surface within the footprint of the building. Testing produced a large quantity of nails, concrete, tile, brick, and other construction materials. The picnic table located adjacent to Shovel Tests 38, 39, and 113 may be sitting on top of additional cultural material. Trench 4 indicates that a brick pathway is leading to the structure (Figure 5-13).

Located in between two oval composite benches in the southwest portion of the project area is a swimming pool exposed in Shovel Tests 117 and 118 (Figure 5-14). Historic aerials do not show the pool, but based on the construction style the pool was likely constructed after the land was sold to USAA. Prior groundskeepers have indicated that the pool was installed either by USAA or SBC for a day camp (personal communication Desiree Salmon 2007). While testing within the pool, historic material that dates to the mid to late $1800 \mathrm{~s}$ and early 1900s was recovered. The pool appears to have been filled in with soil from a site that contained historic material, and then that layer was capped with a mottled white clay fill. St. Augustine grass has grown over most of the pool edge hiding the majority of its outline. The fill itself may derive from some part of the Miraflores Park. The oval composite benches may have acted as seating space beside the pool. Two light posts are situated at either end of the pool that would have lighted the pool during the evening and early morning hours.

\section{Site 41BX1754}

When the project area was nominated for the National Register of Historic Places in 2001, it had not been given a trinomial number. As a result of the archaeological investigations that were conducted during the course of this project, the area was

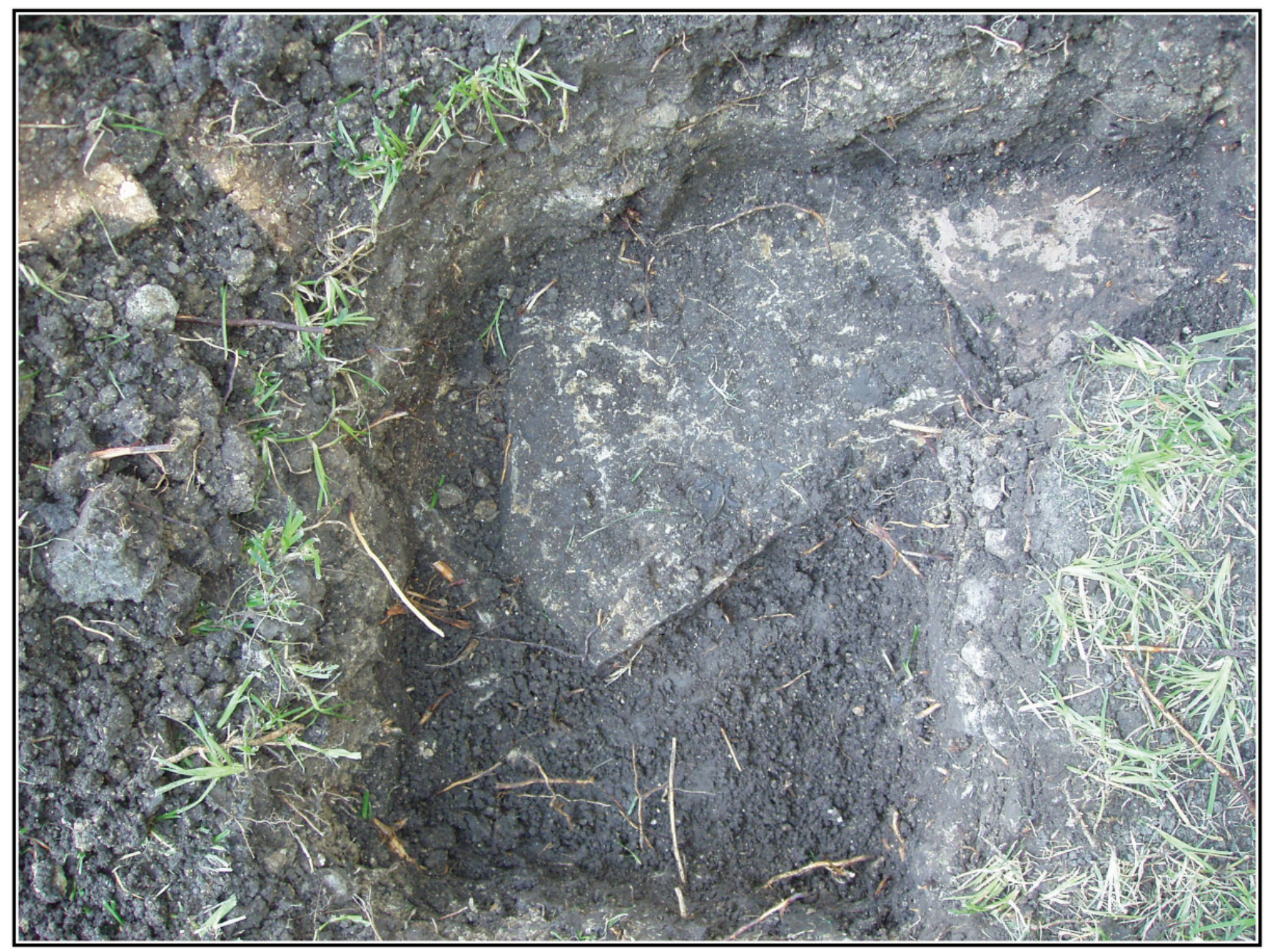

Figure 5-12. Photograph of the unknown feature uncovered in Shovel Test 109. 


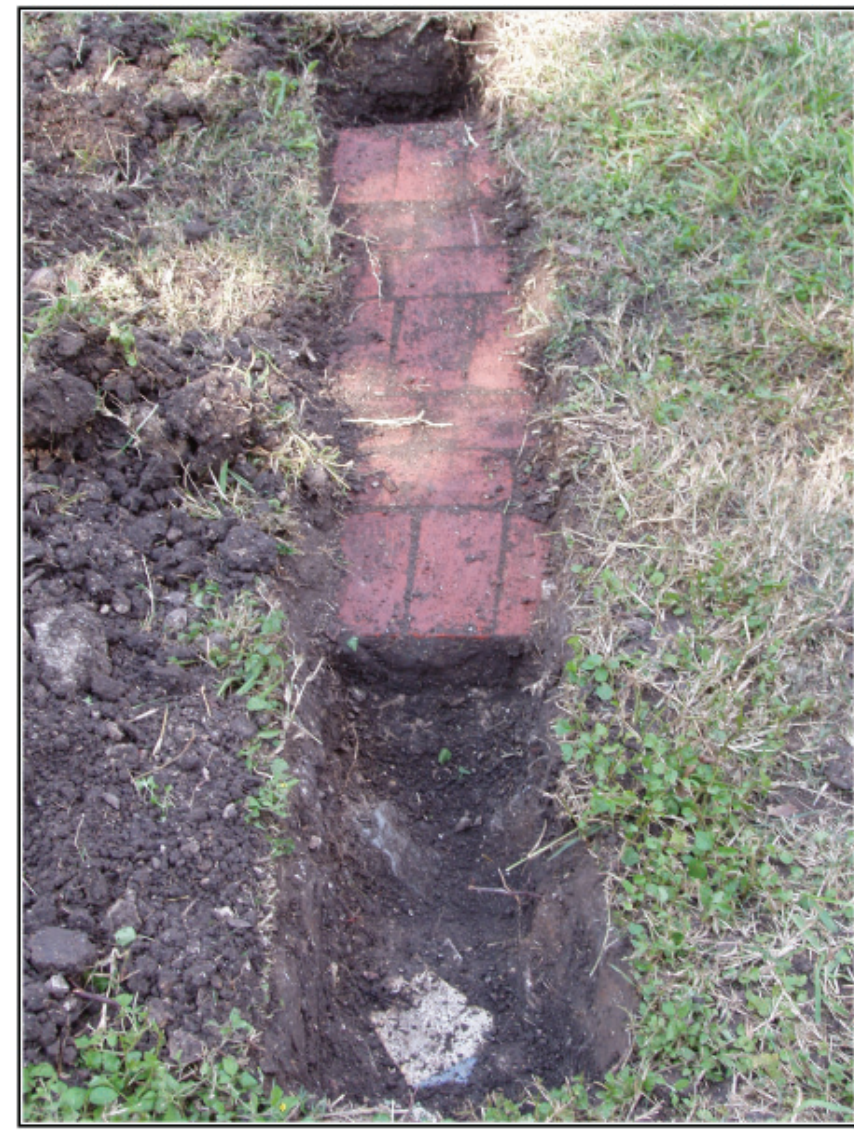

Figure 5-13. Photograph of the brick paved path outside of the library footprint. removal of the picnic benches and cement pads that were installed by USAA, the removal of the large pavilion at the south end of the project area, the removal of soil to expose some of the features currently buried by fill, construction of, or exposure of gravel pathways throughout the park; and the construction of a pedestrian bridge to connect Brackenridge Park to Miraflores. Each of these activities will necessitate subsurface disturbance at the site.

CAR has developed several recommendations to be followed during the course of the construction activities. Based on the results of the investigations conducted to date, CAR recommends the following be taken into consideration as the master plan is developed and implemented: (1) no subsurface disturbance should occur in the northeast portion of the project area where prehistoric cultural material has been located; (2) in areas where soil will be removed to expose architectural features, or in areas that archaeological and archival research indicates that subsurface features are present, CAR recommends that the stripping activities be archaeologically monitored; and (3) CAR recommends an archaeological monitor be present during the removal of the picnic tables and the large pavilion. If features are noted during these activities, further archaeological investigations may be necessary to document the features.

The extraction of the sediment/pollen and geo-technical cores along the east bank of the San Antonio River revealed no cultural material and indicated that pollen preservation was

assigned the trinomial $41 \mathrm{BX} 1754$. 41BX1754 is a multi-component site, with a prehistoric component situated in the northeastern portion of the park property, above the current 100 Year Flood Plain. The remainder of the site consists of the historic component that reflects Dr. Urrutia's vision. Construction of the park began in 1921 and continued over the next three decades. The features that Dr. Urrutia commissioned are all older than 50 years.

\section{Recommendations}

As of yet, undetermined construction activities will occur within the project area to convert the once private park into a public recreational area. Some of the construction activities preliminarily discussed include the

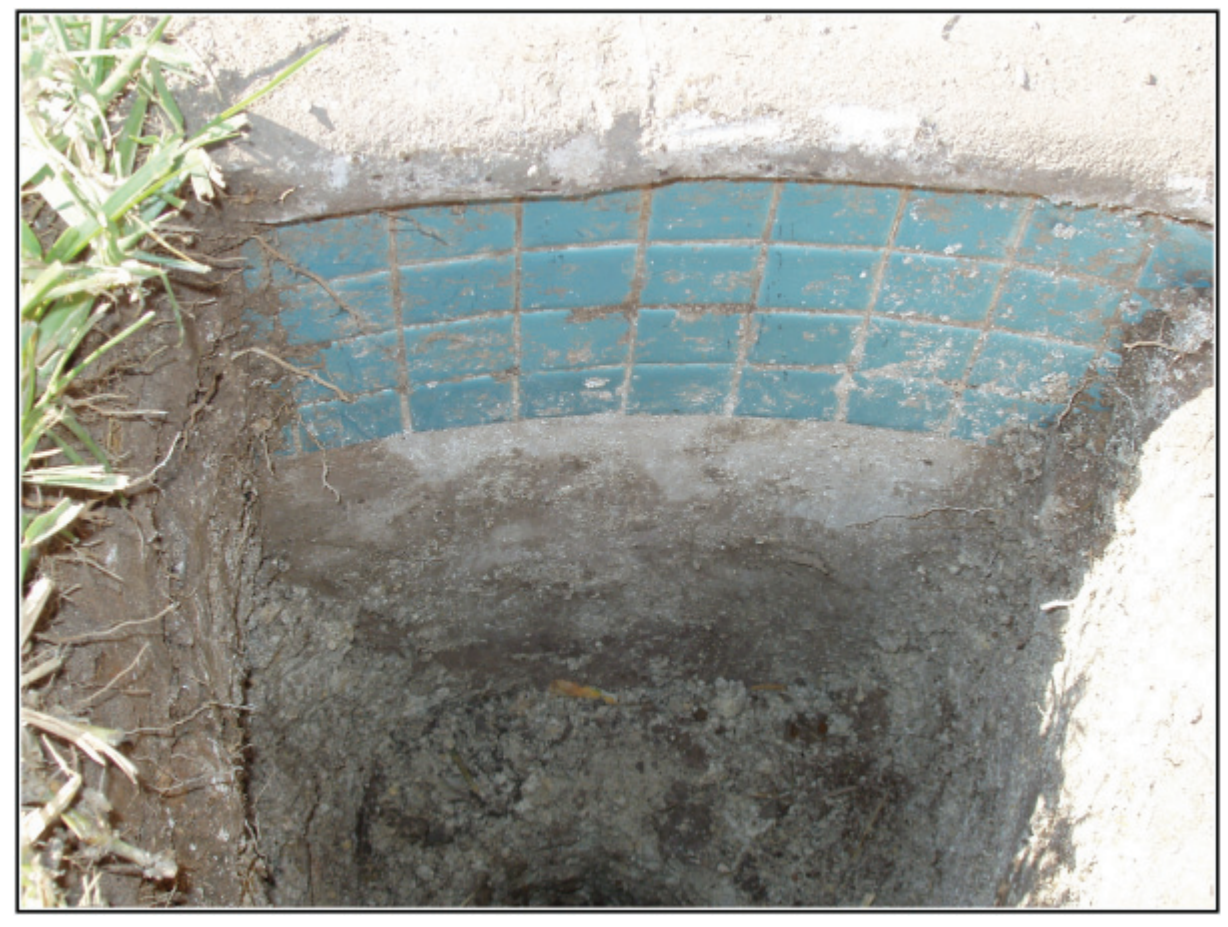

Figure 5-14. Photograph of Shovel Test 117 revealing the edge of the swimming pool. 
poor. Though there will be no perceived impacts on the east bank, the installation of the footbridge between Brackenridge Park and Miraflores Park will have impacts on the west bank of the San Antonio River that will have to be mitigated. CAR recommends that west bank footings and paths of the pedestrian bridge must not impact the Upper Labor Dam or other intact cultural deposits along the west bank. The dam of the Upper Labor Acequia is located at the base of the present pool formed by the old well-fed flow. Investigations conducted in 1996 found that the dam was relatively intact approximately 1 meter below the surface (Cox et al. 1999). The City of San Antonio should have archaeological investigations conducted at the areas of impact along the west bank prior to the installation of the footbridge. 


\section{References Cited}

BCDR (Bexar County Deed Records)

http://www.countyclerk.bexar.landata.com/. Accessed September 2007.

Bement, L.C.

1991 The Thunder Valley Burial Cache: Group Investment in a Central Texas Sinkhole Cemetery. Plains Anthropologist 36(135):97-109.

Black, S.L.

1986 The Clemente and Herminia Hinojosa Site, 41JW8: A Toyah Horizon Campsite in Southern Texas. Special Report, No.

18. Center for Archaeological Research, The University of Texas at San Antonio.

1989 Central Texas Plateau Prairie. In From the Gulf Coast to the Rio Grande: Human Adaptations in Central, South and Lower Pecos Texas. by T. R. Hester, S. L. Black, D. G. Steele, B. W. Olive, A. A. Fox, K. J. Reinhard and L. C. Bement, pp. 17-38. Research Series No. 33. Arkansas Archeological Survey, Fayetteville.

Black, S.L. and D.G. Creel

1997 The Central Texas Burned Rock Midden Reconsidered. In Hot Rock Cooking on the Greater Edwards Plateau: Four Burned Rock Midden Sites in West Central Texas, by S.L. Black, L.W. Ellis, D.G. Creel, and G.T. Goode, pp. 269-305. Studies in Archeology 2. Texas Archeological Research Laboratory, The University of Texas at Austin.

Blair, W.F.

1950 The Biotic Provinces of Texas. Texas Journal of Science 2(1):93-117.

Bousman, B.C.

1998 Paleoenvironmental Change in Central Texas: The Palynological Evidence. Plains Anthropologist. 43(164):201-219.

Bousman, B.C., B.W. Baker and A.C. Kerr

2004 Paleo-Indian Archeology in Texas. In The Prehistory of Texas. edited by T.K. Perttula pp. 15-97. Texas A\&M University Press, College Station.

Brown, D.

1977 Archaeological Survey of Proposed Areas for the Alternative Roadways at Olmos Dam, San Antonio, Texas. Archaeological Survey Report, No. 37. Center for Archaeological Research, The University of Texas at San Antonio.

Chipman, D.

1992 Spanish Texas 1519-1821. University of Texas Press. Austin, Texas.

2007 Spanish Texas. The Handbook of Texas Online. http://www.tsha.utexas.edu/handbook/online/articles/CC/hlc33.html (accessed May 22, 2007).

Collins, M.B.

1995 Forty Years of Archaeology in Texas. Bulletin of the Texas Archeological Society 66:361-400. 
1998 The Place of Wilson-Leonard in Southern Plains Prehistory. In Wilson-Leonard: An 11,000-year Archaeological Record of Hunter-Gatherers in Central Texas. Volume I: Introduction, Background and Syntheses, edited by M.B. Collins, p. 277-291. Studies in Archaeology 31, Texas Archeological Research Laboratory, The University of Texas at Austin. Archeological Studies Program, Report 10, Environmental Affairs Division, Texas Department of Transportation, Austin.

2004 Archeology in Central Texas. In The Prehistory of Texas, edited by Timothy K. Perttula, pp.101-126. Texas A\&M University Press, College Station.

Collins, M.B., D.B. Hudler, S.L. Black

2003 Pavo Real (41BX52): A Paleo-Indian and Archaic Camp and Workshop on the Balcones Escarpment, South-Central Texas. Studies in Archeology 41, Texas Archeological Research Laboratory, The University of Texas at Austin. Archeological Studies Program, Report 50, Environmental Affairs Division, Texas Department of Transportation, Austin.

Cox, I.W., E.D. Johnson, and C.B. Bousman

1999 Excavations for the Upper Labor Dam Site, Brackenridge Park, San Antonio, Bexar County, Texas. Archaeological Survey Report, No. 268. Center for Archaeological Research, The University of Texas at San Antonio.

Dunn, B.

1975 Historical Significance of Incarnate Word Property. Unpublished paper written by the Development Office of Incarnate Word College. On file at the Center for Archaeological Research, The University of Texas at San Antonio.

FEMA (Federal Emergency Management Agency) Map Service Center. http://msc.fema.gov/webapp/wcs/stores/servlet/FemaWelcomeView?storeId=10001\&catalogId= 10001\&langId=-1. Accessed November 2007.

Fentress, C.D.

1986 Wildlife of Bottomlands: Species and Status. In: Bottomland Hardwoods in Texas: Proceedings of an Interagency Workshop on Status and Ecology, edited by C.A. McMahan and R.G. Frye, pp. 37. (Texas Parks and Wildlife Department, Wildlife Division, Austin. March 1987).

Ferring, C.R.

2001 The Archaeology and Paleoecology of the Aubrey Clovis Site (41DN479) Denton County, Texas. Center for Environmental Archaeology. Department of Geography, University of North Texas.

Figueroa, A. and J. J Dowling

2008 Additional Phase II Testing at 41 BX323 in Brackenridge Park, San Antonio, Bexar County, Texas. Archaeological Report, No. 377, Center for Archaeological Research, The University of Texas at San Antonio.

Fox, A.A.

1975 An Archaeological Assessment of the Southern Portion of the Olmos Basin, Bexar County, Texas. Archaeological Survey Report, No. 9. Center for Archaeological Research, The University of Texas at San Antonio.

Fox, A.A., and D.E. Fox

1967 The Classen Rockshelter, 41BX23. Manuscript on file at the Center for Archaeological Research, The University of Texas at San Antonio.

Hester, T.R.

1978 Early Human Occupations in South Central and Southwestern Texas: Preliminary Papers on the Baker Cave and St. Mary's Hall Sites. Manuscript on file at the Center for Archaeological Research, The University of Texas at San Antonio. 
1990 Plainview Artifacts at the St. Mary's Hall Site, South Central Texas. Current Research in the Pleistocene 7:14-17.

1995 The Prehistory of South Texas. Bulletin of the Texas Archeological Society 66:427-459.

Highley, C.L., C. Graves, C. Land, and G. Judson

1978 Archeological Investigations at Scorpion Cave (41ME7) Medina County, Texas. Bulletin of the Texas Archeological Society 49:139-194.

Houk, B.A. and K.A. Miller

2001 Brackenridge Park Rehabilitation Project Archaeological Survey, San Antonio, Bexar County, Texas. SWCA Cultural Resource Report No. 00-331. SWCA, Inc., Austin.

Huebner, J.A.

1991 Late Prehistoric Bison Populations in Central and Southern Texas. Plains Anthropologist 36(137):343-358.

Johnson, L.

1994 The Life and Times of Toyah-Culture Folk: The Buckhollow Encampment Site 41KM16, Kimble County, Texas. Report 38. Office of the State Archeologist, Austin.

Johnson, L. and G.T. Goode

1994 A New Try at Dating and Characterizing Holocene Climates, as well as Archaeological Periods, on the Eastern Edwards Plateau. Bulletin of the Texas Archaeological Society. 65:1-51.

Kalter, A.J., R.M. Rogers and M.N. Smith

2005 Analysis and Reporting for 41FY135, the Sandbur Site, Fayette County, Texas. PBS\&J, Document No. 020388. Archeological Studies Program Report, No. 73. Texas Department of Transportation, Austin.

Katz, S.R., and P.R. Katz

1982 Report of Archeological Testing at 41BX291 in the Southern Olmos Basin, Bexar County, Texas by the 1976 Incarnate Word Archeological Field School. Unpublished report prepared for the Texas Antiquities Committee.

Lukowski, P.D.

1988 Archaeological Investigations at 41BX1, Bexar County, Texas. Archaeological Survey Report, No. 135. Center for Archaeological Research, The University of Texas at San Antonio.

Mauldin, R.P., and D.L. Nickels

2001 An Archaeological Survey of Twin Buttes Reservoir, Tom Green County, Texas. Archaeological Survey Report, No. 300. Center for Archaeological Research, The University of Texas at San Antonio.

Mauldin, R.P., D.L. Nickels, and C.J. Broehm

2003 Archaeological Testing to Determine the National Register Eligibility Status of 18 Prehistoric Sites on Camp Bowie, Brown County, Texas. Archaeological Survey Report, No. 334. Center for Archaeological Research, The University of Texas at San Antonio.

Meltzer, D.J. and M.R. Bever

1995 Paleoindians of Texas: An Update on Texas Clovis Fluted Point Survey. Bulletin of the Texas Archaeological Society $66: 47-81$. 
Miller, K.A., S. Carpenter, L.C. Nordt, C. Howell, and C. Ringstaff

1999 Archaeological Testing of 41BX323 and Portions of the Historic Second Waterworks Canal. Brackenridge Park, San Antonio, Bexar County, Texas. SWCA Cultural Resource Report No. 98-62. SWCA, Inc., Austin.

Nickels, D.L., C.B. Bousman, J.D. Leach, and D.A. Cargill

1998 Test Excavations at the Culebra Creek Site, 41BX126, Bexar County, Texas. Archaeological Survey Report, No. 265. Center for Archaeological Research, The University of Texas at San Antonio; Archeology Studies Program, Report 3, Environmental Affairs Division, Texas Department of Transportation, Austin.

Norwine, J.

1995 The Regional Climate of South Texas: Patterns and Trends. In The Changing Climate of Texas: Predictability and Implications for the Future, edited by J. Norwine, J. Giardino, G. North, and J. Valdes, pp. 138-155. Texas A\&M University Press, College Station.

Orchard, C.D., and T.N. Campbell

1954 Evidence of Early Man from the Vicinity of San Antonio, Texas. Texas Journal of Science 6(4):454-465.

Patterson, L.W.

1988 Chronology of Arrow Point Types in South Texas. La Tierra 15(4):29-33.

Powell, J.F. and D.G. Steele

1994 Diet and Health of Paleoindians: An Examination of Early Holocene Human Dental Remains. In Paleonutrition: The Diet and Health of Prehistoric Americans, edited by K.D. Sobolik, pp. 176-92. Occasional Paper No. 22. Center for Archaeological Investigations, Southern Illinois University, Carbondale.

Prewitt, E.R.

1981 Cultural Chronology in Central Texas. Bulletin of the Texas Archaeological Society 52:65-89.

Quigg, J.M., C. Lintz, F.M. Oglesby, A.C. Earls, C.D. Frederick, W.N. Trierweiler, D. Owsley, and K.W. Kibler

1993 Historic and Prehistoric Data Recovery at Palo Duro Reservoir, Hansford County, Texas. Technical Report 485. Mariah Associates, Inc., Austin.

Ramsdell, C.

1959 San Antonio A Historical and Pictorial Guide. University of Texas Press, Austin.

Ricklis, R.A.

1995 The Ceramics of the Toyah Horizon and the Rockport Phase as Indicators of some Basic Sociocultural Patterns. Bulletin of Texas Archeological Society 66:195-203.

Skinner, S.A.

1981 Aboriginal Demographic Changes in Central Texas. Plains Anthropologist 26(92):111-118.

South Central Texas Regional Water Planning Group (SCTRWPGP)

http://www.watershedexperience.com/ish_vege_areas.html Accessed October 2007.

Southern Regional Climate Center (SRCC)

http://www.srcc.lsu.edu/southernClimate/climatesummaries/ Accessed October 2007. 
Stothert, K.E.

1989 The Archaeology and Early History of the Head of the San Antonio River. Special Publications, Number 5.Southern Texas Archaeological Association. Archaeology Series, Number 3. Incarnate Word College, San Antonio.

Taylor, F.B., R.B. Hailey, and D.L. Richmond

1991 Soil Survey of Bexar County, Texas. U.S. Department of Agriculture Soil Conservation Service. The Soil Conservation Service, Washington, D.C.

THC (Texas Historical Commission)

The Texas Archeological Site Atlas. http://nueces.thc.state.tx.us/. Accessed September 2007.

Toomey, R.S., M.D. Blum, and S. Valastro, Jr.

1993 Late Quaternary Climates and Environments of the Edwards Plateau, Texas. Global and Planetary Change 7:299320.

Turner, S.E. and T.R. Hester

1993 A Field Guide to Stone Artifacts of Texas Indians. Gulf Pub. Co., Houston, Texas.

Weir, F.A.

1976 The Central Texas Archaic. Unpublished Ph.D. dissertation in Anthropology, Washington State University, Pullman.

Westkaemper, S.C.

1985 Three Twentieth Century Gardens: A Heritage of Excellence in San Antonio. Masters Thesis. Louisiana State University and Agricultural and Mechanical College, School of Landscape Architecture. Portion on file at The Center for Archaeological Research. The University of Texas at San Antonio.

Winkler, B.A.

1982 Wild Plant Foods of the Desert Gatherers of West Texas, New Mexico and Northern Mexico: Some Nutritional Values. Unpublished Master's thesis, Department of Anthropology, The University of Texas at Austin. 